\title{
14. NEOGENE FORAMINIFERA FROM THE NORTHEASTERN PACIFIC OCEAN, LEG 18, DEEP SEA DRILLING PROJECT
}

\author{
James C. Ingle, Jr., Department of Geology, School of Earth Science, Stanford University, Stanford, California
}

\section{CONTENTS}

$\begin{array}{ll}\text { Introduction } & 517 \\ \text { General } & 517 \\ \text { Methods and procedures } & 519 \\ \text { Site 172 } & 521 \\ \text { Geologic and stratigraphic setting } & 521 \\ \text { Planktonic foraminifera and age } & 524 \\ \text { Benthonic foraminifera } & 525 \\ \text { Origin of lower Oligocene carbonate ooze } & 525 \\ \text { Site 173 } & 526 \\ \text { Geologic and stratigraphic setting } & 526 \\ \text { Abundance and preservation of foraminifera } & 526 \\ \text { Planktonic foraminifera } & 526 \\ \text { Age, biostratigraphy, and paleo-oceanography } & 527 \\ \text { Benthonic foraminifera and paleobathymetry } & 536 \\ \text { Site 174 } & 537 \\ \text { Geologic and stratigraphic setting } & 537 \\ \text { Abundance and preservation of foraminifera } & 537 \\ \text { Planktonic foraminifera, age, } & \\ \text { and paleo-oceanography } & 537 \\ \text { Benthonic foraminifera and paleobathymetry } & 541 \\ \text { Site 175 } & 542 \\ \text { Geologic and stratigraphic setting } & 542 \\ \text { Abundance and preservation of foraminifera } & 542 \\ \text { Planktonic foraminifera, age, } & \\ \text { and paleo-oceanography } & 542 \\ \text { Benthonic foraminifera and paleobathymetry } & 542 \\ \text { Site 176 } & 545 \\ \text { Geologic and stratigraphic setting } & 545 \\ \text { Abundance and preservation of foraminifera } & 545 \\ \text { Planktonic foraminifera, age, } & 545 \\ \text { and paleo-oceanography } & 548 \\ \text { Benthonic foraminifera and paleobathymetry } & 549 \\ \text { Site 177 } & 549 \\ \text { Geologic and stratigraphic setting } & 549 \\ \text { Abundance and preservation of foraminifera } & \end{array}$

\section{INTRODUCTION}

\section{General}

Leg 18 of the Deep Sea Drilling Project commenced on May 29, 1971, when the Glomar Challenger set sail from Honolulu and traversed a course east across the subtropical Pacific and thence north along the continental margin of North America, arriving in Kodiak, Alaska, July 21, 1971. Ten of the eleven drilling sites were located along the continental margin of North America, beginning with Site 173 located off Cape Mendocino, California, and ending

\section{Site 178}

Planktonic foraminifera, age, and paleo-oceanography

Geologic and stratigraphic setting

Abundance and preservation of foraminifera

Planktonic foraminifera, age, and paleo-oceanography

Benthonic foraminifera and paleobathymetry Site 179

Geologic and stratigraphic setting

Abundance and preservation of foraminifera

Planktonic foraminifera, age, and paleo-oceanography

Benthonic foraminifera and paleobathymetry

Site 180

Geologic and stratigraphic setting

Abundance and preservation of foraminifera

Planktonic foraminifera, age, and paleo-oceanography

Benthonic foraminifera and paleobathymetry Site 181

Geologic and stratigraphic setting

Abundance and preservation of foraminifera

Planktonic foraminifera, age, and paleo-oceanography

Benthonic foraminifera and paleobathymetry

Site 182

Geologic and stratigraphic setting

Abundance and preservation of foraminifera

Planktonic foraminifera, age, and paleo-oceanography

Benthonic foraminifera and paleobathymetry

Faunal reference list

Acknowledgments

References
Page

551

553

553

553

554

554

554

554

556

556

556

556

556

557

557

558

558

558

558

558

558

560

560

560

560

560

560

564

565

with Site 182 off Kodiak, Alaska (Figure 1; Table 1). The primary purposes of this expedition were (a) to test current ideas regarding the Neogene tectonic and sedimentary history of the interface between the Pacific Ocean basin and the continental margin of North America and (b) to gather information on planktonic biostratigraphy beneath and paleo-oceanographic history of the subarctic and temperate water masses characteristic of this region (Figure 2).

A total of 1085 samples from the eleven sites drilled on Leg 18 were examined for foraminifera. Planktonic and benthonic species were found at every site, however, there 


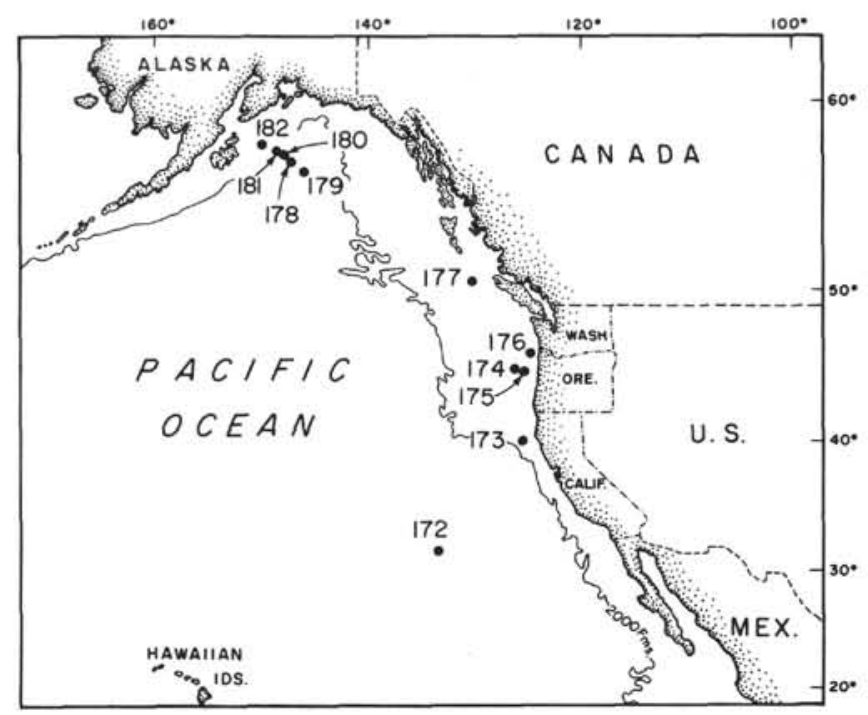

Figure 1. Location of drilling sites occupied on Leg 18, northeastern Pacific Ocean.

TABLE 1

Leg 18 Site Data

\begin{tabular}{|c|c|c|c|}
\hline Site/Hole & Location & $\begin{array}{c}\text { Depth Below } \\
\text { Sea Level } \\
\text { (m) }\end{array}$ & $\begin{array}{l}\text { Depth Below } \\
\text { Sea Floor } \\
\text { (m) }\end{array}$ \\
\hline 172 & $\begin{array}{r}31^{\circ} 32.23^{\prime} \mathrm{N} \\
133^{\circ} 22.36^{\prime} \mathrm{W}\end{array}$ & 4768 & 23 \\
\hline 173 & $\begin{array}{r}39^{\circ} 57.71^{\prime} \mathrm{N} \\
125^{\circ} 27.12^{\prime} \mathrm{W}\end{array}$ & 2927 & 333.5 \\
\hline 174 & $\begin{array}{r}44^{\circ} 53.38^{\prime} \mathrm{N} \\
126^{\circ} 20.80^{\prime} \mathrm{W}\end{array}$ & $\begin{array}{l}2815 \\
2799(A)\end{array}$ & $\begin{array}{l}19 \\
879(\mathrm{~A})\end{array}$ \\
\hline 175 & $\begin{array}{r}44^{\circ} 50.2^{\prime} \mathrm{N} \\
125^{\circ} 14.5^{\prime} \mathrm{W}\end{array}$ & 1999 & 271 \\
\hline 176 & $\begin{array}{r}45^{\circ} 56.0^{\prime} \mathrm{N} \\
124^{\circ} 37.0^{\prime} \mathrm{W}\end{array}$ & 193 & 41 \\
\hline 177 & $\begin{array}{r}50^{\circ} 28.18^{\prime} \mathrm{N} \\
130^{\circ} 12.30^{\prime} \mathrm{W}\end{array}$ & 2006 & 507 \\
\hline 178 & $\begin{array}{r}56^{\circ} 57.38^{\prime} \mathrm{N} \\
147^{\circ} 07.86^{\prime} \mathrm{W}\end{array}$ & 4218 & 794.5 \\
\hline 179 & $\begin{array}{r}56^{\circ} 24.54^{\prime} \mathrm{N} \\
145^{\circ} 59.32^{\prime} \mathrm{W}\end{array}$ & 3781 & 109 \\
\hline 180 & $\begin{array}{r}57^{\circ} 21.76^{\prime} \mathrm{N} \\
147^{\circ} 51.37^{\prime} \mathrm{W}\end{array}$ & 4923 & 470.5 \\
\hline 181 & $\begin{array}{r}57^{\circ} 26.30^{\prime} \mathrm{N} \\
148^{\circ} 27.88^{\prime} \mathrm{W}\end{array}$ & 3086 & 369 \\
\hline 182 & $\begin{array}{r}57^{\circ} 52.96^{\prime} \mathrm{N} \\
148^{\circ} 42.99^{\prime} \mathrm{W}\end{array}$ & 1419 & 123 \\
\hline $182 \mathrm{~A}$ & $\begin{array}{r}57^{\circ} 52.88^{\prime} \mathrm{N} \\
148^{\circ} 43.39^{\prime} \mathrm{W}\end{array}$ & 1434 & 195 \\
\hline
\end{tabular}

are major variations in abundance and preservation characteristics within and between sites. For example, the only foraminifera recovered at Site 172 are marginally preserved early Oligocene species encountered in a thin coccolith ooze near the base of a barren sequence of abyssal brown clays deposited beneath the calcium carbonate compensation level. Alternately, foraminifera are rare or absent within significantly thick intervals of Plio-Pleistocene sediments deposited along the continental margin of Oregon, Washington, and British Columbia (Sites 174 to 177) due to dilution by rapidly deposited turbidites. Sites drilled at lower bathyal and abyssal depths on the Aleutian Abyssal Plain and adjacent to the Aleutian Trench (Sites 178 to 181) are generally characterized by lengthy Plio-Pleistocene intervals barren of foraminifera due to deposition below the calcium carbonate compensation level and dilution by turbidites with well-preserved faunas essentially confined to sediments deposited during the late Pleistocene/Holocene interval. A moderately well preserved early Miocene fauna encountered in a multicolored chalk beneath a thick blanket of terrigenous debris at Site 178 represents a significant deviation from this pattern. Abundance and preservation of foraminifera increase in sediments deposited at shallower depths in this area as exemplified by Pleistocene faunas encountered at Site 182 drilled on a middle bathyal slope off Kodiak Island, Alaska.

In contrast to the marginal character of foraminiferal faunas found at many sites on Leg 18, the 333-meter thick section of terrigenous and biogenous (diatomaceous) sediment penetrated at Site 173 off northern California (Figure 1) contains an outstandingly complete sequence of late Pleistocene through late Oligocene faunas. This site represents the most important sequence encountered on Leg 18 from a paleontologic and biostratigraphic viewpoint. Planktonic and benthonic foraminifera are common and generally well preserved throughout this entire sequence and are accompanied by prolific numbers of diatoms, silicoflagellates, and radiolarians. Calcareous nannofossils are also present in varying abundance allowing comparison and correlation of biozones based on each of these important planktonic groups at a relatively high latitude. Variations in temperature-sensitive subarctic, temperate, and subtropical planktonic foraminiferal biofacies at Site 173 clearly record major oscillations in surface temperature within the California Current system during the Neogene interval, and these events are sensed by other planktonic groups as well. Indeed, the marginal appearances of many subtropical planktonic foraminiferal species within this sequence are governed primarily by paleoclimatic events rather than evolution and limit the use of these species for correlation with standard zonations developed at lower latitudes.

Analyses of benthonic foraminifera at Leg 18 sites provide critical information on the paleobathymetric ${ }^{1}$ history of various portions of the continental margin penetrated, origin of displaced turbidite sediments, and, in some instances, serve as independent means for correlation with the well-studied surface sections exposed along the Pacific Coast of California, Oregon, Washington, British Columbia, and Alaska.

Finally, it is important to note that the thick wedges of Neogene sediments developed along the continental margin of North America and penetrated at a number of sites on Leg 18 represent the product of extremely high rates of sedimentation induced by dynamic variations in climate and tectonic history. The consequent expansion of geologic time in terms of sediment thickness within these deposits provides an ideal setting in which to study Neogene

\footnotetext{
${ }^{1}$ Bathymetric classification of marine environments used in this report is given on Table 2 .
} 

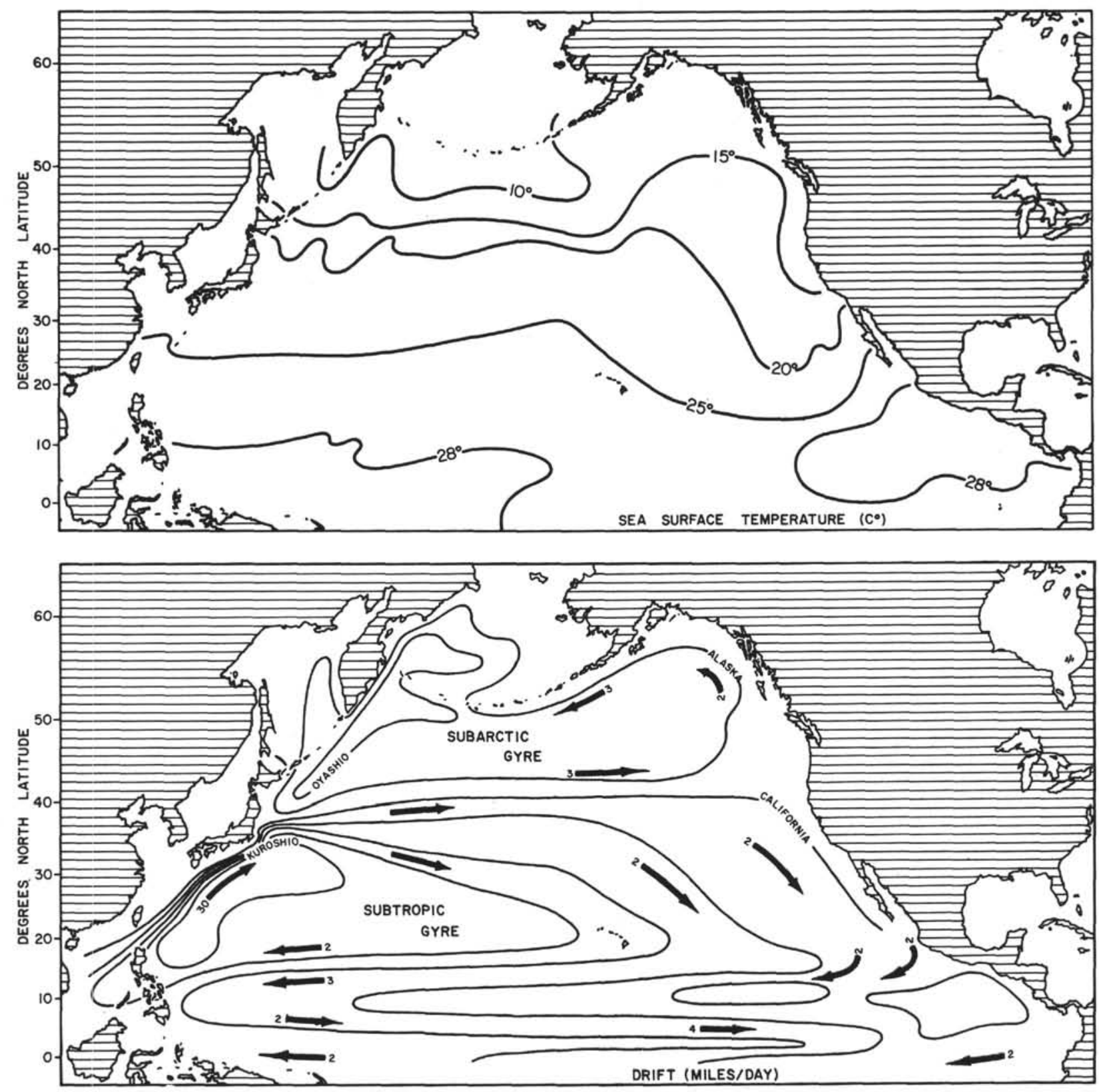

Figure 2. Distribution of surface temperatures and major surface currents in the North Pacific Ocean.

biostratigraphic and paleo-oceanographic events in contrast to the telescoped sections characteristic of the deep sea proper and the structurally complex sequences subaerially exposed along the adjacent continental margin.

\section{Methods and Procedures}

All samples examined were collected by the writer onboard the Glomar Challenger. Core barrels utilized on this vessel are 9.1 meters in length, including a core catcher at the base of each barrel. Each core is cut into six 1.5-meter sections numbered 1 through 6 from the top of the core. Samples taken within a given section are measured in centimeters from the top of the section with a fixed rule in the on-board paleontologic laboratory. Thus, sample designations consist of cruise leg number, site number, core number, section number, and centimeter interval below the top of a given section ${ }^{2}$. Core catcher samples are designated by "CC" rather than an interval in centimeters. Leg number is often deleted from sample designations as site numbers are equally unique.

\footnotetext{
${ }^{2}$ For example, 18-173-14-2 $(120-123 \mathrm{~cm})=$ Leg-site-core-section (interval in $\mathrm{cm}$ ).
} 
TABLE 2

Depth Classification ${ }^{\mathrm{a}}$ of Marine Benthonic Environments Utilized in Leg 18 Foraminiferal Reports

\begin{tabular}{|c|c|}
\hline Benthonic Zone & $\begin{array}{l}\text { Depth Range } \\
\text { (m) }\end{array}$ \\
\hline Supralittoral & Splash Zone to HHW \\
\hline Littoral (Intertidal) ${ }^{\mathrm{b}}$ & HHW to LLW \\
\hline Inner Shelf (Inner Sublittoral) ${ }^{\mathrm{f}}$ & LLW to $50 \mathrm{~m}$ \\
\hline Outer Shelf (Outer Sublittoral) ${ }^{\mathrm{f}}$ & $50 \mathrm{~m}$ to $150 \mathrm{~m}^{\mathrm{c}}$ \\
\hline Upper Bathyal & $150 \mathrm{~m}$ to $500 \mathrm{~m}$ \\
\hline Upper Middle Bathyal & $500 \mathrm{~m}$ to $1500 \mathrm{~m}^{\mathrm{d}}$ \\
\hline Lower Middle Bathyal & $1500 \mathrm{~m}$ to $2500 \mathrm{~m}$ \\
\hline Lower Bathyal & $2500 \mathrm{~m}$ to $4000 \mathrm{~m}$ \\
\hline Abyssal & $4000 \mathrm{~m}$ to $6500 \mathrm{~m}$ \\
\hline Hadal (Trenches) & $6500 \mathrm{~m}+$ \\
\hline
\end{tabular}

aModified from Hedgpeth (1957).

${ }^{b}$ Preferred terms are in italics

The photic zone ranges from 0 to $150 \mathrm{~m}$.

dCorresponds to the approximate position of the oxygen minimum zone.

${ }^{\mathrm{e}}$ Average depth of the world oceans is about $3800 \mathrm{~m}$.

$\mathrm{f}_{\text {Equivalent to outer and inner neritic of some authors. }}$

Samples obtained generally consisted of 10 cubic $\mathrm{cm}$ of sediment, although core catcher samples generally consisted of larger amounts of material. Unconsolidated samples were prepared by soaking in water with the occasional addition of small amounts of hydrogen peroxide to aid disaggregation. In cases where consolidated shales or mudrocks were encountered, foraminifera were recovered by drying the sample, immersion in kerosene, decantation of kerosene, and immersion in water, whereupon displacement of kerosene by water disaggregated the sample.

Disaggregated samples were routinely washed through a 250 mesh ( 0.62 micron openings) screen and dried. In cases where foraminifera were seriously diluted by diatomaceous sediment or sand, they were concentrated by flotation in carbon tetrachloride. The residues from floated concentrates were also carefully examined for specimens.

Quantitative analyses were made of planktonic foraminiferal faunas at Sites 173, 174, 175, 176, 177, 179, 180, and 181 and of benthonic foraminifera at Site 176, with species abundances reported as a percent of total planktonic or benthonic specimens counted in a given sample; percentages were not calculated for samples containing less than 20 specimens. Qualitative analyses of species abundances were made at Sites 172, 178, and 182 with abundance reported as $\mathrm{A}=$ abundant (more than 100 specimens), $\mathrm{C}=$ common $(26-100$ specimens), $\mathrm{F}=$ few (10-25 specimens), $R=$ rare (less than 10 specimens), and $B$ = barren. Qualitative notations regarding the abundance and preservation of planktonic foraminiferal faunas in each sample containing planktonic foraminifera are given in tables of species distribution for each site. Preservation is recorded as follows: $\mathrm{G}=$ good, $\mathrm{M}=$ moderate, and $\mathrm{P}=$ poor. Table 3 lists samples barren of foraminifera at all sites and Table 4 lists the abundance and preservation of benthonic foraminifera at Sites 172, 174, 175, 177, 179, 180, 181, and 182.

Samples studies in this report are deposited in the Micropaleontologic Laboratory of the Department of Geology at Stanford University, Stanford, California. Specimens

TABLE 3

Samples Barren of Foraminifera at Sites 172, $173,174,175,176,177,178,179,180,181$, and 182

\section{Site 172}

$172-1-1(17-19 \mathrm{~cm})$
$172-1-1(147-149)$
$172-1-2(147-149)$
$172-1-3(147-149)$
$172-1-4(147-149)$
$172-1-5(147-149)$
$172-1-6(147-149)$
$172-1(C C)$
$172-2-1(143-145)$
$172-2-2(146-148)$
$172-2-4(147-149)$
$172-2-5(114-116)$
$172-2(C C)$
$172-3-1(66-67)$
$172-3-2(147-149)$
$172-3-4(130-132)$

Site 173

$173-7-4(52-54 \mathrm{~cm})$ $173-9-1(52-54)$

173-14-3(52-54)

$173-21-1(52-54)$

$173-22-3(52-54)$

$173-22-4(52-54)$

173-22-5(46-48)

$173-23-2(52-54)$

173-28-1(85-87)

$173-28-2(50-52)$

173-29(CC)

$173-31-1(142-144)$

173-32(CC)

\section{Site 174}

174A-9-2(130-132 cm)

174A-9-5(145-146)

174A-17-1(60-62)

174A-18-1(108-110)

$174 \mathrm{~A}-26-2(120-122)$

174A-28(CC)

$174 \mathrm{~A}-29-1(130-132)$

174A-37-1(113-114)

174A-38-1(120-122)

174A-39-1(146-148)

$174 \mathrm{~A}-40-5(107-109)$

Site 175

$175-6-3(80-82 \mathrm{~cm})$

$175-10-3(72-74)$

$175-10-4(73-75)$

$175-10-5(73-75)$

$175-14-5(90-92)$

175-21(CC)

Site 176

$176-2-6(62-64 \mathrm{~cm})$

Site $177 \mathrm{~A}$

$177 \mathrm{~A}-4-3(56-58 \mathrm{~cm})$

177A-5-2(61-63)

177A-5-3(62-64)

177A-5-6(66-68)

$177 \mathrm{~A}-6-2(60-62)$

177 A-6-3(61-63)

177 A-6-4(64-66)

$177 \mathrm{~A}-7$ (CC)
Site 177A - Continued

177A-8-1(60-62)

177A-8-2(60-62)

177A-8-5(53-55)

177A-8-6(65-67)

$177 \mathrm{~A}-8(\mathrm{CC})$

177A-9-2(80-82)

177A-9-4(45-47)

$177 A-9-5(60-62)$

177A-9-6(40-42)

$177 \mathrm{~A}-9$ (CC)

177A-10-2(60-62)

$177 \mathrm{~A}-10-4(85-87)$

$177 \mathrm{~A}-10$ (CC)

177A-11-2(61-63)

177A-11-3(62-64)

177A-11-4(61-63)

177A-11(CC)

177A-12-1(112-114)

177A-12-2(60-62)

177A-12-3(60-62)

177A-13-1(130-132)

177A-14(CC)

177A-15-1(103-105)

177A-15-2(60-62)

177A-15-3(123-125)

177A-15-4(52-54)

177A-15-5(60-62)

177A-15(CC)

177A-16-2(21-23)

177 A-16(CC)

177A-17-2(60-62)

177A-17-3(60-62)

177A-17-4(62-64)

177 A-17(CC)

177A-18-1(59-61)

177A-18-2(55-57)

$177 \mathrm{~A}-18-3(56-58)$

177 A-18(CC)

177A-19-2(63-65)

177A-19-3(65-66)

177A-19(CC)

177A-20-2(87-89)

$177 \mathrm{~A}-20-3(78-79)$

$177 \mathrm{~A}-20$ (CC)

177A-21-2(61-62)

177A-21-3(72-73)

177A-21(CC)

177A-22-2(71-72)

177A-22-3(36-37)

177A-22-4(76-77)

177A-23-1(83-84)

177A-23-2(91-92)

177A-23-3(96-97)

177A-23-4(50-51)

177 A-23(CC)

177 A-24(CC)

177A-26-1(57-59)

177A-26-1(91-92)

$177 \mathrm{~A}-26(\mathrm{CC})$

Site 178

$178-1-3(40-42 \mathrm{~cm})$

$178-1-4(60-62)$

178-2-2(60-62)

$178-3-3(30-32)$

$178-3-4(30-32)$

$178-4-4(105-107)$ 
TABLE 3 - Continued

\begin{tabular}{|c|c|}
\hline Site 178 - Continued & Site 178 - Continued \\
\hline $178-5-3(130-132 \mathrm{~cm})$ & $178-37-2(47-49 \mathrm{~cm})$ \\
\hline $178-6-3(102-104)$ & $178-37-3(43-45)$ \\
\hline $178-8-4(90-92)$ & $178-37-4(80-82)$ \\
\hline $178-8(\mathrm{CC})$ & $178-37(\mathrm{CC})$ \\
\hline $178-9-3(85-87)$ & $178-38-1(65-67)$ \\
\hline $178-10-2(90-92)$ & $178-38(\mathrm{CC})$ \\
\hline $178-11-2(60-62)$ & $178-39-2(87-89)$ \\
\hline $178-11(\mathrm{CC})$ & $178-39-3(38-40)$ \\
\hline $178-15-1(95-97)$ & $178-39-4(41-43)$ \\
\hline $178-15-2(62-64)$ & $178-39-5(135-137)$ \\
\hline $178-15(\mathrm{CC})$ & $178-39-6(109-111)$ \\
\hline $178-16-2(67-69)$ & $178-40(\mathrm{CC})$ \\
\hline $178-16-3(63-65)$ & $178-43-1(56-58)$ \\
\hline $178-16-4(63-65)$ & $178-43-3(57-59)$ \\
\hline $178-16(\mathrm{CC})$ & $178-43(\mathrm{CC})$ \\
\hline $178-17-2(80-82)$ & $178-44-2(86-88)$ \\
\hline $178-17-3(87-89)$ & $178-44-4(88-90)$ \\
\hline $178-17-4(70-72)$ & $178-44-5(102-104)$ \\
\hline $178-17-5(70-72)$ & $178-44-6(86-88)$ \\
\hline $178-17(\mathrm{CC})$ & $178-44(\mathrm{CC})$ \\
\hline $178-18-2(99-101)$ & $178-45-1(36-38)$ \\
\hline $178-19-2(88-90)$ & $178-45(\mathrm{CC})$ \\
\hline $178-19-3(64-66)$ & $178-45-2(95-96)$ \\
\hline $178-19(\mathrm{CC})$ & $178-46(\mathrm{CC})$ \\
\hline $178-20-3(56-58)$ & $178-47-1(121-123)$ \\
\hline $178-20-4(55-57)$ & $178-47-2(75-77)$ \\
\hline $178-20-5(63-65)$ & $178-47(\mathrm{CC})$ \\
\hline $178-20-6(62-64)$ & $178-48-1(69-71)$ \\
\hline $178-20(\mathrm{CC})$ & $178-48(\mathrm{CC})$ \\
\hline $178-21-3(63-65)$ & $178-49-1(64-66)$ \\
\hline $178-21(\mathrm{CC})$ & $178-49(\mathrm{CC})$ \\
\hline $178-22(\mathrm{CC})$ & $178-50-1(33-35)$ \\
\hline $178-23-2(62-64)$ & $178-50-2(70-71)$ \\
\hline $178-23(\mathrm{CC})$ & $178-50-3(21-22)$ \\
\hline $178-24-2(63-65)$ & $178-50(\mathrm{CC})$ \\
\hline $178-24-3(62-64)$ & $178-51-1(96-98)$ \\
\hline $178-25-3(99-101)$ & $178-51-2(62-64)$ \\
\hline $178-25(\mathrm{CC})$ & $178-51(\mathrm{CC})$ \\
\hline $178-26(\mathrm{CC})$ & $178-52-2(104-106)$ \\
\hline $178-27(\mathrm{CC})$ & $178-52(\mathrm{CC})$ \\
\hline $178-28-2(128-130)$ & $178-53-1(71-72)$ \\
\hline $178-28-3(120-122)$ & $178-53(\mathrm{CC})$ \\
\hline $178-28-5(130-132)$ & $178-54-1(36-37)$ \\
\hline $178-28-6(100-102)$ & $178-54-2(110-111)$ \\
\hline $178-28(\mathrm{CC})$ & $178-54-3(37-38)$ \\
\hline $178-29-3(90-92)$ & $178-54-3(110-111)$ \\
\hline $178-29-5(97-99)$ & $178-54-4(27-28)$ \\
\hline $178-30-2(117-119)$ & $178-54-4(144-145)$ \\
\hline $178-30(\mathrm{CC})$ & $178-54(\mathrm{CC})$ \\
\hline $178-31-1(132-134)$ & $178-56(\mathrm{CC})$ \\
\hline $178-31(\mathrm{CC})$ & \\
\hline $178-31-1(80-82)$ & Site 179 \\
\hline $178-31-2(117-119)$ & $179-3-3(84-86 \mathrm{~cm})$ \\
\hline $178-31-3(136-138)$ & $179-5-6(60-62)$ \\
\hline $178-31(\mathrm{CC})$ & $179-7-1(17-19)$ \\
\hline $178-33-2(15-17)$ & $179-7-1(58-60)$ \\
\hline $178-33-3(50-52)$ & $179-7-2(67-69)$ \\
\hline $178-33-5(54-56)$ & $179-7-3(56-58)$ \\
\hline $178-33(\mathrm{CC})$ & $179-7-4(60-62)$ \\
\hline $178-34-2(59-61)$ & $179-8-2(53-55)$ \\
\hline $178-34-3(85-87)$ & $179-8-3(60-62)$ \\
\hline $178-34-4(46-48)$ & $179-8-4(26-28)$ \\
\hline $178-34-5(65-67)$ & $179-8-5(42-44)$ \\
\hline $178-34-6(113-115)$ & $179-8-6(33-35)$ \\
\hline $178-34(C C)$ & $179-8(\mathrm{CC})$ \\
\hline 178-35-2(92-94) & $179-9-1(40-42)$ \\
\hline $178-35(C C)$ & $179-9-2(40-42)$ \\
\hline $178-36-1(128-130)$ & $179-9-3(20-21)$ \\
\hline $178-36-2(24-26)$ & $179-9-4(100-102)$ \\
\hline $\begin{array}{l}178-36(C C) \\
178-37-2(37-39)\end{array}$ & $179-9-5(83-85)$ \\
\hline
\end{tabular}

TABLE 3 - Continued

\begin{tabular}{ll}
\hline Site $179-$ Continued & Site $181-$ Continued \\
$179-9-6(40-42 \mathrm{~cm})$ & $181-12-3(94-96 \mathrm{~cm})$ \\
$179-9(C \mathrm{C})$ & $181-15-1(139-141)$ \\
$179-10-2(44-46)$ & $181-15-2(80-82)$ \\
$179-10-3(60-62)$ & $181-15-3(70-72)$ \\
$179-10-4(63-65)$ & $181-15-5(65-67)$ \\
$179-10(C \mathrm{C})$ & $181-16(\mathrm{CC})$ \\
$179-11-1(118-120)$ & $181-17-2(45-47)$ \\
$179-11-3(103-105)$ & $181-17-4(65-67)$ \\
$179-11-4(64-66)$ & $181-17-6(54-56)$ \\
$179-11-4(128-130)$ & $181-18-4(140-142)$ \\
& $181-19-1(140-141)$ \\
Site 180 & $181-20-1(47-48)$ \\
$180-4(C C)$ & $181-21-1(95-97)$ \\
$180-8-3(38-40 \mathrm{~cm})$ & $181-22-1(134-135)$ \\
$180-17-1(94-96)$ & $181-24-1(99-101)$ \\
$180-17-2(52-54)$ & $181-25-1(120-121)$ \\
$180-18-1(67-69)$ & $181-25-2(94-95)$ \\
$180-18-3(70-72)$ & $181-26-1(94-95)$ \\
$180-19-1(54-56)$ & $181-26(C C)$ \\
$180-24-3(60-62)$ & $181-27-1(126-127)$ \\
Site 181 & $181-27-2(70-72)$ \\
$181-2(C C)$ & $181-28-1(139-141)$ \\
$181-3-3(93-95 \mathrm{~cm})$ & $181-28(C C)$ \\
$181-4-2(104-106)$ & $181-29-1(54-56)$ \\
$181-4-3(108-110)$ & $181-29-2(31-33)$ \\
$181-4-4(108-110)$ & $181-29(C C)$ \\
$181-5-2(91-93)$ & $181-30-1(33-34)$ \\
$181-6-2(85-87)$ & \\
$181-8-4(88-90)$ & Site 182 \\
$181-11-1(71-73)$ & None \\
\hline a Abundance and preservation of benthonic species at Site 176 is \\
given on Table 15; abundance of benthonic specimens at Site 173 \\
generally parallels abundance and preservation of planktonic spe- \\
cies, whereas benthonic species are rare or absent at Site 178 \\
& \\
& \\
1 &
\end{tabular}

of planktonic foraminiferal species cited in this report have been deposited in the Micropaleontologic Collection of this same institution.

\section{SITE 172}

\section{Geologic and Stratigraphic Setting}

Site 172 was drilled in a small abyssal "sediment pond" located within an area of uneven bottom topography $140 \mathrm{~km}$ south of the Murray Fracture Zone and north of the Molokai Fracture Zone between California and Hawaii (Figure 1). This area has been characterized as a magnetically disturbed zone by Atwater and Menard (1970). The primary objectives in drilling this site were (a) to determine the age of the seismic "basement" in this area as an aid in deciphering the spreading history of this portion of the Pacific and (b) to obtain additional biostratigraphic information along a traverse paralleling $140^{\circ} \mathrm{W}$ longtitude sampled on previous legs.

Drilling at Site 172 penetrated 23 meters of red brown zeolitic deep-sea clays completely barren of calcareous foraminifera with the exception of a sparse early Oligocene fauna contained within a thin $(15 \mathrm{~cm})$ coccolith-rich ooze at 22 meters (Core 3). Basalt was encountered at 23 meters, however, seismic records suggest that up to 100 meters of sediment may be present in this "sediment pond," in turn suggesting that this particular basalt may simply represent a sill and not true "oceanic basement." 
TABLE 4

Abundance and Preservation of Benthonic Foraminifera at Sites $172,174,175,177,179,180,181$, and $182^{\mathrm{a}}$

\begin{tabular}{l}
\hline \multicolumn{1}{c}{ Sample } \\
\hline Site 172 \\
$172-2-3(147-149 \mathrm{~cm})$ \\
$172-2-6(147-149)$ \\
$172-3-3(147-149)$ \\
$172-3-4(50-52)$ \\
$172-3-5(147-149)$ \\
$172-3-6(41-43)$ \\
$172-3-6(54-56)$ \\
$172-3-6(140-142)$ \\
$172-3(C C)$
\end{tabular}

Site 174

$174-1-1(110-112 \mathrm{~cm})$

174-1(CC)

174-2(CC)

174-3(CC)

Hole 174A

$174 \mathrm{~A}-1-5(80-82 \mathrm{~cm})$ $174 \mathrm{~A}-1-1(115-117)$

$174 \mathrm{~A}-1(\mathrm{CC})$

$174 \mathrm{~A}-2-1(28-30)$

$174 \mathrm{~A}-2-2(137-139)$

$174 \mathrm{~A}-2(\mathrm{CC})$

174A-3-2(52-54)

$174 \mathrm{~A}-3-2(80-82)$

$174 \mathrm{~A}-3(\mathrm{CC})$

$174 \mathrm{~A}-4-2(120-122)$

174A-4-3(90-92)

$174 \mathrm{~A}-4(\mathrm{CC})$

$174 \mathrm{~A}-5-1(130-132)$

$174 \mathrm{~A}-5-2(52-54)$

$174 \mathrm{~A}-5(\mathrm{CC})$

$174 \mathrm{~A}-6-3(20-22)$

$174 \mathrm{~A}-6(\mathrm{CC})$

$174 \mathrm{~A}-7-1(140-142)$

$174 \mathrm{~A}-7-3(22-24)$

$174 \mathrm{~A}-7-6(12-14)$

174A-7(CC)

$174 \mathrm{~A}-8(\mathrm{CC})$

174A-11-1(80-82)

174A-11-2(130-132)

$174 \mathrm{~A}-11-4(55-57)$

174A-11-6(90-92)

$174 \mathrm{~A}-11$ (CC)

174A-12-1(130-132)

174A-12-2(103-105)

174A-12(CC)

174A-13-2(110-112)

$174 \mathrm{~A}-13$ (CC)

174A-14-3(104-107)

$174 \mathrm{~A}-14(\mathrm{CC})$

174A-15-3(128-130)

174A-15-4(125-127)

174A-15(CC)

174A-16-2(77-79)

174A-16-2(110-112)

$174 \mathrm{~A}-16(\mathrm{CC})$

174A-17-1(120-122)

174A-17-3(129-131)

174A-17(CC)

174A-19-4(45-47)

$174 \mathrm{~A}-19(\mathrm{CC})$

174A-20-3(60-62)

174A-20(CC)

174A-21-3(98-100)

174A-22-2(114-116)

Abundance Preservation

R
R
R
F
R
R
F
C
F

$\mathrm{P}$
$\mathrm{P}$
$\mathrm{M}$
$\mathrm{M}$
$\mathrm{P}$
$\mathrm{P}$
$\mathrm{M}$
$\mathrm{P}$
$\mathrm{P}$

R
F
R
R

M

M

M

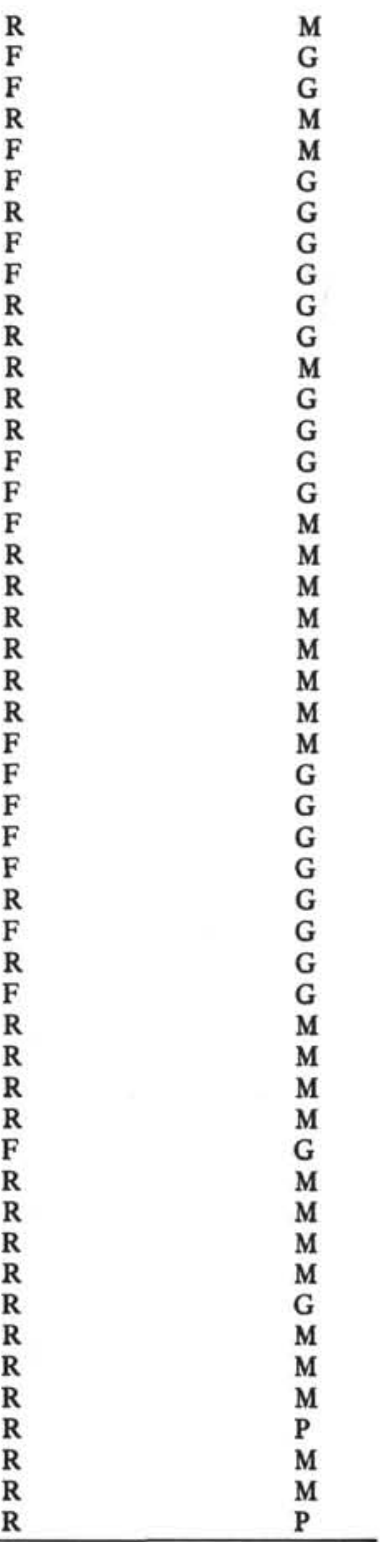

TABLE 4 - Continued

\begin{tabular}{|c|c|c|}
\hline Sample & Abundance & Preservation \\
\hline \multicolumn{3}{|l|}{ Hole 174A - Continued } \\
\hline $\begin{array}{l}174 A-23-2(33-35 \mathrm{~cm}) \\
174 A-23-4(20-22) \\
174 A-23-4(33-35) \\
174 A-23(C C) \\
174 A-24(C C) \\
174 A-25-3(140-142) \\
174 A-25-4(4-6) \\
174 A-25-5(69-71) \\
174 A-25(C C) \\
174 A-27(C C) \\
174 A-29-2(56-58) \\
174 A-29(C C) \\
174 A-31-2(62-64) \\
174 A-31(C C) \\
174 A-32-1(108-110) \\
174 A-32(C C) \\
174 A-33-2(97-99) \\
174 A-34-2(105-107) \\
174 A-34-4(92-94) \\
174 A-34(C C) \\
174 A-35(C C) \\
174 A-36(C C) \\
174 A-37-4(33-35) \\
174 A-37(C C) \\
174 A-38(C C) \\
174 A-39(C C) \\
174 A-39-2(75-77) \\
174 A-39-3(22-24) \\
174 A-40-2(15-17) \\
174 A-40-3(48-50) \\
174 A-40-4(64-66) \\
174 A-40-5(61-63)\end{array}$ & $\begin{array}{l}\mathrm{R} \\
\mathrm{R} \\
\mathrm{R} \\
\mathrm{R} \\
\mathrm{F} \\
\mathrm{R} \\
\mathrm{R} \\
\mathrm{R} \\
\mathrm{R} \\
\mathrm{R} \\
\mathrm{R} \\
\mathrm{R} \\
\mathrm{R} \\
\mathrm{F} \\
\mathrm{R} \\
\mathrm{C} \\
\mathrm{F} \\
\mathrm{R} \\
\mathrm{R} \\
\mathrm{C} \\
\mathrm{F} \\
\mathrm{F} \\
\mathrm{R} \\
\mathrm{R} \\
\mathrm{R} \\
\mathrm{F} \\
\mathrm{R} \\
\mathrm{R} \\
\mathrm{R} \\
\mathrm{R} \\
\mathrm{R} \\
\mathrm{R}\end{array}$ & $\begin{array}{l}\mathrm{M} \\
\mathrm{M} \\
\mathrm{M} \\
\mathrm{P} \\
\mathrm{M} \\
\mathrm{P} \\
\mathrm{P} \\
\mathrm{M} \\
\mathrm{M} \\
\mathrm{M} \\
\mathrm{M} \\
\mathrm{M} \\
\mathrm{M} \\
\mathrm{G} \\
\mathrm{M} \\
\mathrm{M} \\
\mathrm{M} \\
\mathrm{M} \\
\mathrm{M} \\
\mathrm{G} \\
\mathrm{G} \\
\mathrm{G} \\
\mathrm{P} \\
\mathrm{P} \\
\mathrm{P} \\
\mathrm{P} \\
\mathrm{M} \\
\mathrm{M} \\
\mathrm{P} \\
\mathrm{M} \\
\mathrm{P} \\
\mathrm{P}\end{array}$ \\
\hline
\end{tabular}

Site 175

$175-1-1(101-103 \mathrm{~cm})$

175-1-2(70-72)

175-1-3(70-72)

$175-1-4(81-83)$

175-1(CC)

175-2-1(100-102)

175-2-2(68-70)

$175-2-3(68-70)$

$175-2-4(85-87)$

175-2(CC)

175-3-1(68-70)

$175-3-2(67-69)$

$175-3-3(85-87)$

$175-3-4(83-85)$

$175-3-4(91-93)$

175-3-5(68-70)

175-3(CC)

175-4-1(78-80)

175-4-2(60-62)

175-4-3(67-69)

$175-4-4(80-82)$

175-4-5(60-62)

$175-4$ (CC)

$175-5-1(60-62)$

$175-5-2(85-87)$

$175-5-3(84-86)$

$175-5-4(84-86)$

$175-5-5(27-29)$

175-5-6(65-67)

175-5(CC)

175-6-1(79-81)

175-6-2(83-85)

$175-6-4(78-80)$

$175-6-5(85-87)$
G
G
M
M
M
M
M
M
M
G
G
M
M
M
M
G
G
M
M
M
M
P
M
P
P
P
M
M
M
M
M
M
M
M 
TABLE 4 - Continued

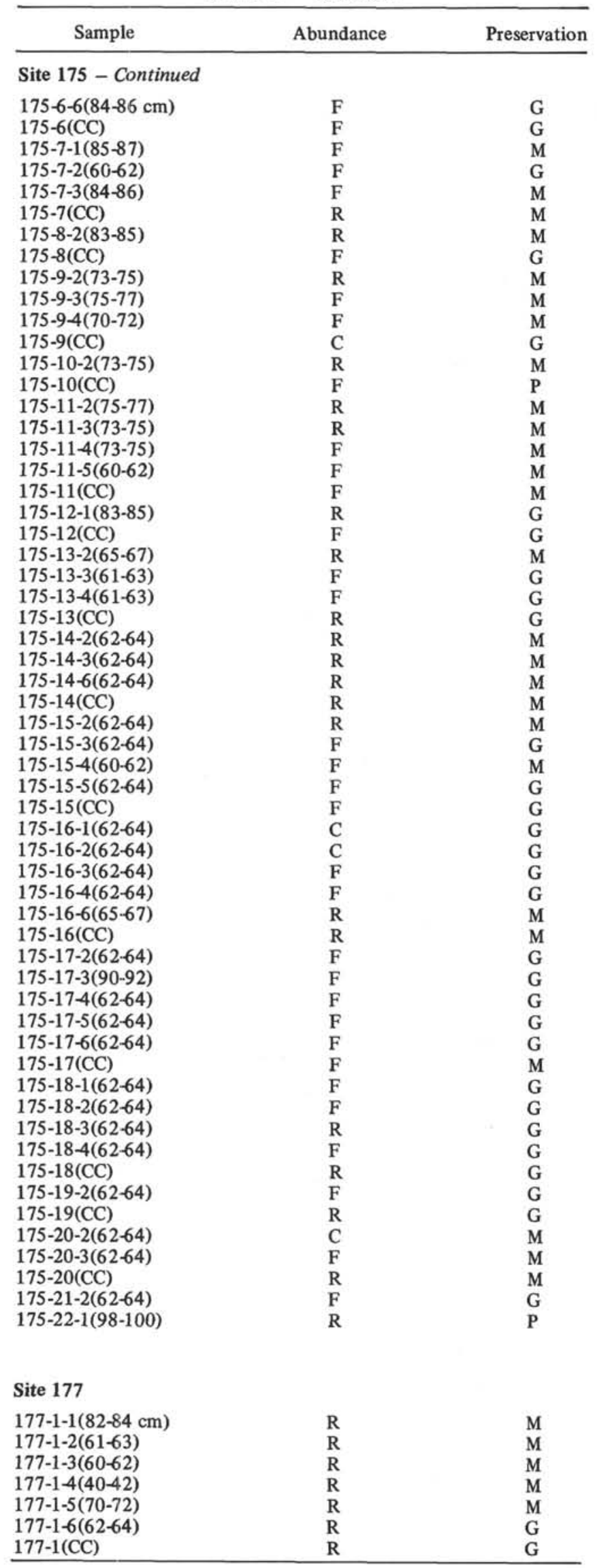

TABLE 4 - Continued

\begin{tabular}{lcc}
\hline \multicolumn{1}{c}{ Sample } & Abundance & Preservatio \\
\hline Hole 177A & & \\
$177 \mathrm{~A}-1-1(62-64 \mathrm{~cm})$ & $\mathrm{R}$ & $\mathrm{G}$ \\
$177 \mathrm{~A}-1-2(64-66)$ & $\mathrm{F}$ & $\mathrm{G}$ \\
$177 \mathrm{~A}-1(\mathrm{CC})$ & $\mathrm{C}$ & $\mathrm{G}$ \\
$177 \mathrm{~A}-2-6(104-106)$ & $\mathrm{F}$ & $\mathrm{M}$ \\
$177 \mathrm{~A}-2(\mathrm{CC})$ & $\mathrm{R}$ & $\mathrm{M}$ \\
$177 \mathrm{~A}-3-1(91-93)$ & $\mathrm{R}$ & $\mathrm{M}$ \\
$177 \mathrm{~A}-3-2(61-63)$ & $\mathrm{R}$ & $\mathrm{M}$ \\
$177 \mathrm{~A}-3-3(62-64)$ & $\mathrm{R}$ & $\mathrm{M}$ \\
$177 \mathrm{~A}-3-6(62-64)$ & $\mathrm{R}$ & $\mathrm{M}$ \\
$177 \mathrm{~A}-4-1(125-127)$ & $\mathrm{R}$ & $\mathrm{M}$ \\
$177 \mathrm{~A}-4-2(63-65)$ & $\mathrm{F}$ & $\mathrm{M}$ \\
$177 \mathrm{~A}-4-5(61-63)$ & $\mathrm{F}$ & $\mathrm{M}$ \\
$177 \mathrm{~A}-4(\mathrm{CC})$ & $\mathrm{R}$ & $\mathrm{M}$ \\
$177 \mathrm{~A}-5-1(65-67)$ & $\mathrm{R}$ & $\mathrm{M}$ \\
$177 \mathrm{~A}-14-2(54-56)$ & $\mathrm{F}$ & $\mathrm{M}$ \\
$177 \mathrm{~A}-14-4(60-62)$ & $\mathrm{F}$ & \\
$177 \mathrm{~A}-14-4(130-132)$ & &
\end{tabular}

Site 179

$179-1-1(138-140 \mathrm{~cm})$

179-1-3(108-110)

179-1(CC)

179-2-1(93-95)

179-2-2(93-95)

$179-2-3(39-41)$

$179-2-4(55-57)$

$179-2-5(33-35)$

179-2-5(90-92)

179-2(CC)

179-3-1(115-117)

179-3-2(86-88)

179-3-4(104-106)

179-3-5(39-41)

179-3-6(115-117)

179-3(CC)

179-4-1(131-132)

$179-4-3(60-62)$

$179-4$ (CC)

$179-5-1(55-57)$

179-5-3(40-42)

$179-5-4(40-42)$

$179-5-5(50-52)$

179-5(CC)

179-6-2(69-71)

179-6(CC)

$179-7-5(102-104)$

179-7(CC)

179-11-2(135-137)

179-12-1(142-144)

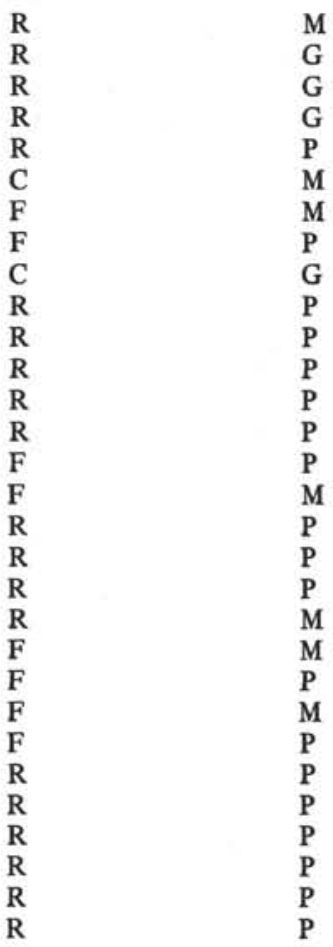

Site 180

$180-1-2(40-42 \mathrm{~cm})$

180-1(CC)

180-2-2(45-47)

$180-3-1(137-139)$

180-3(CC)

180-4-1(100-102)

$180-4-3(35-37)$

180-6(CC)

$180-7-1(80-82)$

180-7(CC)

180-9(CC)

$180-10(C C)$

180-11(CC)

$180-12-1(62-64)$

180-12(CC)

$180-13(\mathrm{CC})$

180-14(CC)

\begin{tabular}{ll}
$\mathrm{R}$ & $\mathrm{P}$ \\
$\mathrm{R}$ & $\mathrm{M}$ \\
$\mathrm{R}$ & $\mathrm{M}$ \\
$\mathrm{R}$ & $\mathrm{M}$ \\
$\mathrm{R}$ & $\mathrm{P}$ \\
$\mathrm{R}$ & $\mathrm{P}$ \\
$\mathrm{R}$ & $\mathrm{G}$ \\
$\mathrm{R}$ & $\mathrm{P}$ \\
$\mathrm{R}$ & $\mathrm{M}$ \\
$\mathrm{R}$ & $\mathrm{M}$ \\
$\mathrm{R}$ & $\mathrm{M}$ \\
$\mathrm{R}$ & $\mathrm{M}$ \\
$\mathrm{F}$ & $\mathrm{M}$ \\
$\mathrm{F}$ & $\mathrm{M}$ \\
$\mathrm{R}$ & $\mathrm{M}$ \\
$\mathrm{F}$ & $\mathrm{M}$ \\
$\mathrm{R}$ & $\mathrm{M}$ \\
\hline
\end{tabular}


TABLE 4 - Continued

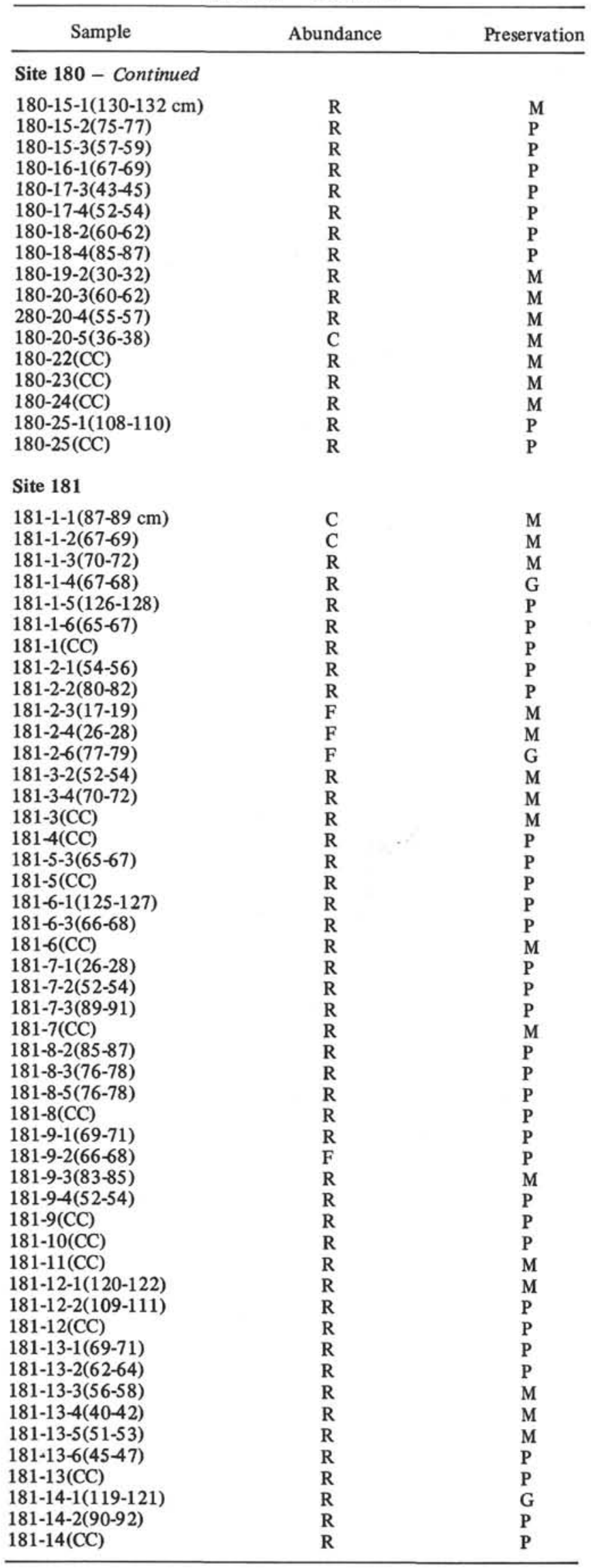

TABLE 4 - Continued

\begin{tabular}{|c|c|c|}
\hline Sample & Abundance & Preservation \\
\hline \multicolumn{3}{|l|}{ Site 181 - Continued } \\
\hline $\begin{array}{l}181-15-5(63-65 \mathrm{~cm}) \\
181-15(C C) \\
181-17-3(45-47) \\
181-17(C C) \\
181-18-2(110-112) \\
181-18-3(55-57) \\
181-18(C C) \\
181-20(C C) \\
181-21(C C) \\
181-22(C C) \\
181-23-1(127-128) \\
181-23(C C) \\
181-24(C C) \\
181-25(C C) \\
181-27(C C) \\
181-30(C C)\end{array}$ & $\begin{array}{l}\mathrm{R} \\
\mathrm{R} \\
\mathrm{R} \\
\mathrm{R} \\
\mathrm{R} \\
\mathrm{R} \\
\mathrm{R} \\
\mathrm{R} \\
\mathrm{R} \\
\mathrm{R} \\
\mathrm{R} \\
\mathrm{R} \\
\mathrm{R} \\
\mathrm{R} \\
\mathrm{R} \\
\mathrm{R}\end{array}$ & $\begin{array}{l}\mathrm{M} \\
\mathrm{M} \\
\mathrm{P} \\
\mathrm{G} \\
\mathrm{M} \\
\mathrm{M} \\
\mathrm{M} \\
\mathrm{M} \\
\mathrm{M} \\
\mathrm{M} \\
\mathrm{P} \\
\mathrm{M} \\
\mathrm{M} \\
\mathrm{M} \\
\mathrm{M} \\
\mathrm{M}\end{array}$ \\
\hline \multicolumn{3}{|l|}{ Site 182} \\
\hline $\begin{array}{l}182-1-1(112-114 \mathrm{~cm}) \\
182-1-2(69-71) \\
182-1-3(54-56) \\
182-1-4(50-52) \\
182-1-5(53-55) \\
182-1-6(47-49) \\
182-1(C C) \\
182-3-1(86-88) \\
182-3-2(106-108) \\
182-3(C C) \\
182-4(C C) \\
182-5(C C) \\
182-6(C C) \\
182 A-1(C C)\end{array}$ & $\begin{array}{l}\text { F } \\
C \\
C \\
C \\
C \\
C \\
C \\
F \\
F \\
F \\
F \\
\text { R } \\
C \\
\text { F }\end{array}$ & $\begin{array}{l}\text { G } \\
\text { G } \\
M \\
G \\
G \\
G \\
G \\
G \\
M \\
M \\
G \\
P \\
M \\
M\end{array}$ \\
\hline
\end{tabular}

\section{Planktonic Foraminifera and Age}

A total of less than fifty specimens of eight relatively solution-resistant species of early Oligocene planktonic foraminifera were recovered from five samples scattered through Sections 3, 4, 5, and 6 of Core 3. All of these specimens appear to have their origin in the thin coccolithrich ooze first encountered in Section 3 and well developed in Section 4 of Core 3 (about $22 \mathrm{~m}$ ). Specimens found in Sections 5 and 6 likely represent elements displaced by disturbance within the core barrel (indicated by wavy vertical "stringers" of coccolith-rich ooze in Sections 5 and 6). The paucity of planktonic foraminifera within this interval, despite the abundance of calcareous nannofossils, attests to the severe dissolution of these forms even during the Oligocene when the calcium carbonate compensation level may have been depressed below 5000 meters in this area (Arrhenius, 1963; Heath, 1969). Moreover, the relatively few complete specimens recovered exhibit solution effects in the form of thin test walls, pitting, and loss of internal structure. Common fragments of broken planktonic tests provide evidence of their former abundance and later dissolution.

The reduced nature of the planktonic foraminiferal fauna contained within the coccolith ooze at 22 meters precludes precise biostratigraphic resolution of this horizon. Table 5 illustrates the limited stratigraphic distribution of the species identified. Two of the species encountered, Catapsydrax dissimilis and Globorataloides suteri, have 
TABLE 5

Abundance and Stratigraphic Distribution of Planktonic Foraminifera, Site 172

\begin{tabular}{|c|c|c|c|c|c|c|}
\hline $\begin{array}{l}\text { Core, Section, } \\
\text { Interval (cm) }\end{array}$ & 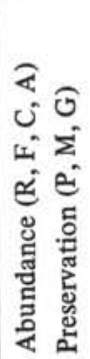 & 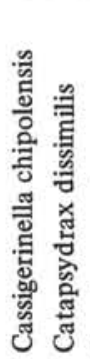 & 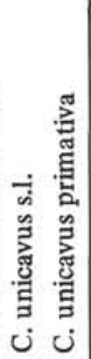 & 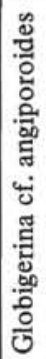 & 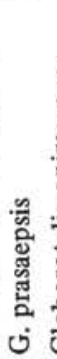 & 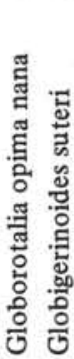 \\
\hline \begin{tabular}{|l}
$3-3(147-149)$ \\
$3-4(50-52)$ \\
$3-5(147-149)$
\end{tabular} & $\begin{array}{ll}\mathrm{R} & \mathrm{P} \\
\mathrm{R} & \mathrm{P} \\
\mathrm{R} & \mathrm{P}\end{array}$ & F & R R & & R 1 & $\begin{array}{ll} & \mathrm{R} \\
\mathrm{R} & \\
\mathrm{R} & \mathrm{R}\end{array}$ \\
\hline $\begin{array}{l}3-6(54-55) \\
3-6(140-142) \\
3(C C)\end{array}$ & $\begin{array}{ll}\mathrm{R} & \mathrm{P} \\
\mathrm{R} & \mathrm{P} \\
\mathrm{R} & \mathrm{P}\end{array}$ & R R & $\begin{array}{l}\mathrm{R} \\
\mathrm{R} \\
\mathrm{R}\end{array}$ & & R & R \\
\hline
\end{tabular}

relatively long ranges spanning the late Eocene through early Miocene, however, the cooccurrence of Cassigerinella chipolensis, Catapsydrax unicavus s.l., C. unicavus primativa, Globigerina cf. angiporoides, G. prasaepsis, and Globorotalia opima nana allow placement of this fauna within the interval assigned by Blow (1969) to his zones P. 18 or P. 19 of the lower Oligocene. The uppermost ranges of Globigerina cf. angiporoides and $G$. prasaepsis are particularly diagnostic of this interval. Furthermore, the absence of Globorotalia opima opima, another generally solutionresistant species common in middle and upper Oligocene sediments, supports this interpretation. Finally, the coccolith flora identified within the calcareous ooze is assigned to the Ericsonia subdistichus Zone of Roth et al. (1971) corroborating the early Oligocene age assignment.

\section{Benthonic Foraminifera}

Fragments and extremely rare specimens of broken arenaceous benthonic foraminifera occur at widely scattered horizons within the otherwise barren sequence of abyssal clays cored at Site 172. Calcareous benthonic foraminifera were found only within the lower Oligocene calcareous ooze at 22 meters (Core 3) with displaced specimens encountered in the disturbed sections below this horizon. The complex ultrastructure of many calcareous benthonic foraminifera (Towe and Cifelli, 1967) apparently allows their tests to more readily resist rapid dissolution compared with planktonic species, and the calcareous benthonic fauna found at 22 meters is relatively diverse and moderately well preserved (Table 6). A total of more than 20 benthonic species are present at this horizon, including Pleurostomella elliptica, P. alternans, Stilostomella lepidula, Gyroidina soldani s.1., Vulvulina pennatula, Nuttaloides umbonifera, and Melonis aff. pompilioides. None of these species are known to be stratigraphically diagnostic and all represent typical elements of the mid-Tertiary to Recent lower bathyal-abyssal benthonic foraminiferal biofacies of the North Pacific Ocean. However, it must be noted that these apparently long-ranging deep-water species groups have not been closely scrutinized and detailed study may well reveal their biostratigraphic utility.
TABLE 6

Benthonic Foraminifera Identified at Site 172

Bulimina translucens Parker

Cassidulina subglobosa quadrata Cushman and Hughes

Cassidulina subglobosa subglobosa Brady

Cibicides kullenbergi Parker.

Dentalina sp.

Eggerella bradyi (Cushman)

Ellipsonodosaria sp.

Gyroidina lamarckiana (d'Orbigny)

Gyroidina soldani (d'Orbigny)

Gyroidina sp.

Martinotiella sp.

Melonis affinis (Reuss)

Melonis aff. pompilioides (Fichtell and Moll)

Nonion sp.

Nuttallides umbonifera (Cushman)

Oridorsalis tener (Brady)

Pleurostomella alternans Schwager

Pleurostomella elliptica Galloway and Heminway

Pleurostomella praegerontica Cushman and Stainforth

Pullenia quinqueloba (Reuss)

Stilostomella lepidula (Schwager)

Stilostomella sp.

Ivigerina auberiana d'Orbigny

Vulvulina pennatula (Batsch)

\section{Origin of Lower Oligocene Carbonate Ooze}

Water depth at Site $172(4768 \mathrm{~m})$ is just below the present upper limit of the calcium carbonate compensation level (CCL) in this are (Heath, 1969), and the predominant lithology at this site indicates most of the column was deposited beneath this critical level during almost the entire interval represented. Thus, the abrupt and brief appearance of an Oligocene coccolith-rich ooze within this sequence represents a significant sedimentary event. Although Heath (1969) favors an apparent increase in bottom water temperature (Emiliani, 1954) to depress the CCL during the mid-Tertiary interval, the widespread occurrence of Oligocene calcareous oozes in the tropical and subtropical Pacific argue for increased productivity as an equally powerful primary mechanism responsible for the appearance of this lithofacies. The abrupt and repeated appearances of this lithofacies within mid-Tertiary sequences of deep-sea clays located along the margin of this region of high productivity (including Site 172) are also consistent with this view. Moreover, substantial evidence is at hand that indicates a significant portion of the Oligocene was characterized by intense polar refrigeration (Devereux, 1967; Wolfe and Hopkins, 1967; Cifelli, 1969; Addicott, 1969; Margolis and Kennett, 1971; and others) with a consequent increase in atmospheric and oceanographic processes (Arrhenius, 1963) in turn triggering increased productivity with possible polarward expansion of the carbonate ooze facies. It now appears that this phenomenon may also have been aided by the direct introduction of boreal surface water into the mid-Pacific due to early and middle Tertiary spreading events in the South Pacific (Kennett, et al., 1972).

\footnotetext{
${ }^{3}$ See Chapter 15 (this volume) by $\mathrm{S}$. Wise for an extended discussion of the origin and diagenesis of the coccolith-rich ooze encountered at Site 172.
} 


\section{SITE 173}

\section{Geologic and Stratigraphic Setting}

Site 173 is located on the lower continental slope immediately south of Cape Mendocino, northern California (Figure 1) at a water depth of 2927 meters. The original objectives at this site were to examine the sedimentary history of the Delgada Submarine Fan as a function of displacement along the San Andreas Fault, to examine depositional processes in detail within a fan environment, and to obtain a biostratigraphic reference section representative of events within the California Current province. Drilling demonstrated that fan sediments do not compose a major portion of the sedimentary column at this site; however, the section encountered did provide a remarkably complete and prolifically fossiliferous late Pleistocene through late Oligocene sequence representing a nearly continuous record of planktonic productivity within a cooler portion of the California Current system. The extraordinary biostratigraphic value of this particular section is enhanced by the cooccurrence of well-preserved siliceous microfossils (diatoms, radiolarians, and silicoflagellates), as well as calcareous nannofossils and planktonic foraminifera.

Drilling and continuous coring at Site 173 penetrated 320 meters of terrigenous and biogenous sediment. An andesite of unusual character was encountered at 320 meters (Core 36) and drilling was terminated in this rock at 333.5 meters. The sedimentary column at Site 173 is readily divisible into three first-order lithologic units. The uppermost unit consists of 138 meters (Cores 1 to 15) of fine terrigenous muds with infrequent fine sands deposited during the early Pliocene through late Pleistocene interval. The second unit, encountered at 138 to 285 meters (Cores 16 to 31), is composed of diatomaceous muds and diatomites with rare sands, volcanic ash, and infrequent horizons rich in calcareous nannofossils representing deposition during the early through late Miocene. The third and oldest unit consists of lower Miocene through upper Oligocene glauconitic mud and nannofossil ooze found between 285 and 320 meters (Cores 32 to 35 ) just above the andesite forming the basement unit.

It is important to note that the relatively thick unit of diatomaceous sediments found at Site 173 has its counterpart in the siliceous shales and diatomites of the Miocene Monterey Shale (and units of equivalent lithology and age) commonly exposed in the Coast Ranges of California and elsewhere along the Pacific Coast. Likewise, the younger terrigenous unit is similar in age and lithology to a number of well-known bathyal Plio-Pleistocene sections exposed along the continental margin in these same onshore areas.

More specifically, the approximately 2000 meters of latest Miocene through Pleistocene bathyal mudstones, siltstones, and turbidite sands assigned to the Pullen, Eel River, and Rio Del formations ${ }^{4}$ exposed at Centerville Beach on the northern flank of Cape Mendocino (Ogle, 1953) represent a structurally deformed but conterminous sequence with the upper 138 meters of Plio-Pleistocene

\footnotetext{
${ }^{4}$ The so-called Wildcat Series.
}

sediment penetrated at Site 173. This large disparity in thickness between the onshore unit and the equivalent deep-sea section gives clear evidence of the massive increase in rate of sedimentation at the immediate continental margin versus the outer continental slope. Plio-Pleistocene foraminiferal events noted at Site 173 have also been recorded within the Wildcat Series (Ingle, 1968) allowing direct correlation across the continent-ocean interface at this site.

\section{Abundance and Preservation of Foraminifera}

Planktonic and benthonic foraminifera are abundant to common and well preserved within the Pleistocene and Pliocene terrigenous clastics encountered in Cores 1 through 15 ( 0 to $138.5 \mathrm{~m}$ ) with the exception of isolated barren samples in Cores 7, 9, and 14 (Table 7). Moderately to well-preserved faunas are generally common to few within upper through lower Miocene diatom-rich muds and diatomites (Cores 15 to $31 ; 138$ to $285.5 \mathrm{~m}$ ) with specimens becoming rarer in the lowest portions of this sequence. However, the number of specimens per unit volume of sediment is generally low due to dilution of prolific numbers of diatom frustules, and planktonic specimens are more abundant than benthonic specimens. Dilution of foraminiferal tests within these biogenous sediments commonly required specimens to be concentrated using carbon tetrachloride. Samples barren of all foraminifera occurred at infrequent intervals in Cores $21,22,23,28,29$, and 31 (Table 3).

Cores 32 and 33 ( 304.5 to $320 \mathrm{~m}$ ) are completely barren of foraminifera with common to rare specimens present in the lower Miocene/upper Oligocene nannofossil ooze within Cores 34 and 35 (285.5 to $304.5 \mathrm{~m}$ ). An anomalous Pliocene assemblage containing Globorotalia puncticulata is present within disturbed sediment at the base of Core 35 $(313$ to $320 \mathrm{~m})$ representing downhole slumping or displacement by drilling operations.

\section{Planktonic Foraminifera}

\section{Introduction and Previous Work}

Site 173 is located directly beneath the track of the California Current, a major eastern boundary current carrying cool water as far south as $24^{\circ}$ latitude in the marginal northeastern Pacific (Figure 2). This fact together with a mid-latitude position readily explains the general low diversity of Pleistocene through Oligocene planktonic faunas recovered at this site.

The overall subarctic to temperate aspect of Neogene planktonic foraminiferal faunas in this area has been previously established in studies made of faunas contained within bathyal marine sediments exposed in the Coast Ranges of California (Bandy and Kolpack, 1963; Ingle, 1963, 1967; Lipps, 1964, 1967; Bandy and Ingle, 1970). These same reports along with others (Ingle, 1972; McKeel and Lipps, 1972; Lipps and Kalisky, 1972; Bandy, 1971, 1972) have also illustrated that a series of cool, temperate, and subtropical biofacies appear within the mid-Tertiary to Recent interval within this area, reflecting major and minor oscillations of surface temperature within the California 
Current system during this interval ${ }^{5}$. These oscillations have allowed only abbreviated appearances of subtropical and tropical species within this area, in turn creating problems in correlation with zonal schemes developed in lower latitude areas. However, the occasional and sometimes common occurrence of tropical-subtropical elements at Site 173 allow tentative correlations to be made with the standard Neogene planktonic zones erected by Banner and Blow (1965) and as detailed by Blow (1969). Placement of zonal and epoch boundaries as defined by Blow (1969) is sometimes difficult in the absence of key species and because end points of stratigraphic ranges of warmer water species are often the result of oscillations in surface temperature rather than evolution.

Although there is a paucity of tropical indices within the planktonic sequence encountered at Site 173, biostratigraphic resolution is enhanced by the periodic latitudinal migrations of temperature-sensitive biofacies across this area representing distinct paleo-oceanographic events. In addition, definitive boreal and transitional water mass species are common and provide datum surfaces only infrequently recognized at lower latitudes. For example, the initial appearance of Globigerina pachyderma s.l. in the late Miocene of New Zealand (Jenkins, 1967; Kennett, 1968 a, b), Japan (Saito, 1963; Ikebe et al., 1972), and California (Ingle, 1967; Bandy, 1972) appears coincident and presents a useful datum surface in higher latitude areas approximately correlative with Blow's (1969) zone N.12. Furthermore, the distinctive coiling habit of this species is an apparent function of surface temperature (Bandy, 1960; Ericson, 1959) in turn providing an extremely useful biostratigraphic-paleo-oceanographic tool in higher latitude areas. Evidence indicates exclusively sinistral populations of this species are confined to waters where surface temperature hovers between $5^{\circ}$ and $8^{\circ} \mathrm{C}$, whereas exclusively dextral populations are indicative of surface temperatures higher than $15^{\circ} \mathrm{C}$ (Bandy et al., 1971, p. 19). The sensitivity of this character is strikingly illustrated in studies of Holocene-Pleistocene planktonic faunas in deep basins off southern California (Kheradpir, 1969; Morin, 1971). Repeated analyses have demonstrated that sinistral populations indicative of subarctic surface temperature appear in the late Miocene, mid-Pliocene, and Pleistocene intervals along the Pacific Coast of North America (Bandy, 1960, 1967; Ingle, 1967; Bandy and Ingle, 1970; Bandy et al., 1969; Kheradpir, 1969; and others) with intervening intervals marked by dextral or mixed populations. This general pattern is duplicated during the same interval in New Zealand (Jenkins, 1967; Kennett, 1967, 1968) and Japan (Asano et al., 1969) and was corroborated once again at Site 173.

Finally, it should be noted that the biostratigraphic usefulness of the climatically induced oscillations in planktonic biofacies and transitional water mass species common to this area was also demonstrated in analysis of Pleistocene through late Miocene sediments found at Site 36 (Olsson, 1971) located northwest of Site 173 near the western edge

\footnotetext{
${ }^{5}$ Neogene paleo-oceanography of the northeastern Pacific is discussed more fully in Chapter 32 of this volume.
}

of the California Current system. Indeed, paleontologic expressions of climatic events offer a means of correlation across latitude independent of the inherent variation in stratigraphic ranges of critical zone indices and allow biostratigraphic events to be placed against a framework defined by major physical events sensed most distincly within mid- and higher latitude regions.

\section{Age, Biostratigraphy, and Paleo-oceanography ${ }^{6}$}

Pleistocene (Zones N 23 and N 22)

Pleistocene planktonic faunas occur in Cores 1 through 8 $(0-70 \mathrm{~m})$ at Site 173 and are dominated by populations of Globigerina pachyderma (Figure 3; Table 7) with significant but generally lower abundances of the $G$. bulloides complex including $G$. bulloides bulloides, G. bulloides quadrilatera, and $G$. bulloides umbilicata. Minor accessory species include Globigerina quinqueloba, Globigerinita glutinata, and G. uvula. This biofacies is characteristic of the California Current at this latitude today (Bradshaw, 1959; Ingle, 1967) as it has been throughout most of the Pleistocene and Pliocene interval.

The latest Pleistocene-Holocene interval equivalent to zone N. 23 is likely represented in Core $1(0-5.3 \mathrm{~m})$ by dominantly dextral coiling populations of Globigerina pachyderma indicative of surface temperatures equivalent to or slightly higher than those extant in this area today. Rare occurrences of Globoquadrina dutertrei and Globorotalia inflata also mark this interval. The base of this interval (Core $1 ; 1 \mathrm{~m}$ ) is thought to correlate with the significant post-glacial rise in surface temperature dated at 11,000 years B.P. ${ }^{7}$ in cores obtained beneath the California Current in areas both north and south of Site 173 (Bandy, 1967; Duncan et al. 1970; Kheradpir, 1970; Morin, 1971). Faunas below $1 \mathrm{~m}$ in Cores 1 through 8 are correlated with Pleistocene zone N. 22 on the basis of correlations with climatic events and radiometric-paleomagnetic chronology reported in the North Pacific (Kent et al., 1971). It is of interest here to note that Globigerina bulloides umbilicata common to just below the top of Core 1 at Site 173 has not been reported from the Recent subartic-cool temperate biofacies of the North Pacific and may represent a useful index to the zone N. 22-23 boundary in the North Pacific area and elsewhere. ${ }^{8}$

The major glacial portion of the later Pleistocene is represented by exclusively dextral populations of Globigerina pachyderma in Cores 2 through $4(6-28 \mathrm{~m})$ at Site 173 ; surface temperatures during this interval are interpreted as hovering near $5^{\circ}$ or $6^{\circ} \mathrm{C}$ with slightly warmer intervals indicated by the brief and rare appearance of Globorotalia inflata. The appearance of mixed dextral-sinistral coiling populations of Globigerina pachyderma in Cores 4 through 7 along with minor occurrences of Globigerinoides ruber,

\footnotetext{
${ }^{6} \mathrm{Faunal}$ analyses are presented in descending chronologic order as a function of their initial appearance in the drilling record.

${ }^{7}$ B.P. $=$ before the present.

${ }^{8} \mathrm{H}$. Ujiie (personal communication, 1972) reports that this same variant is a useful index to Pleistocene sediments in the Sea of Japan.
} 
TABLE 7

Abundance and Stratigraphic Distribution of Planktonic Foraminifera, Site 173a

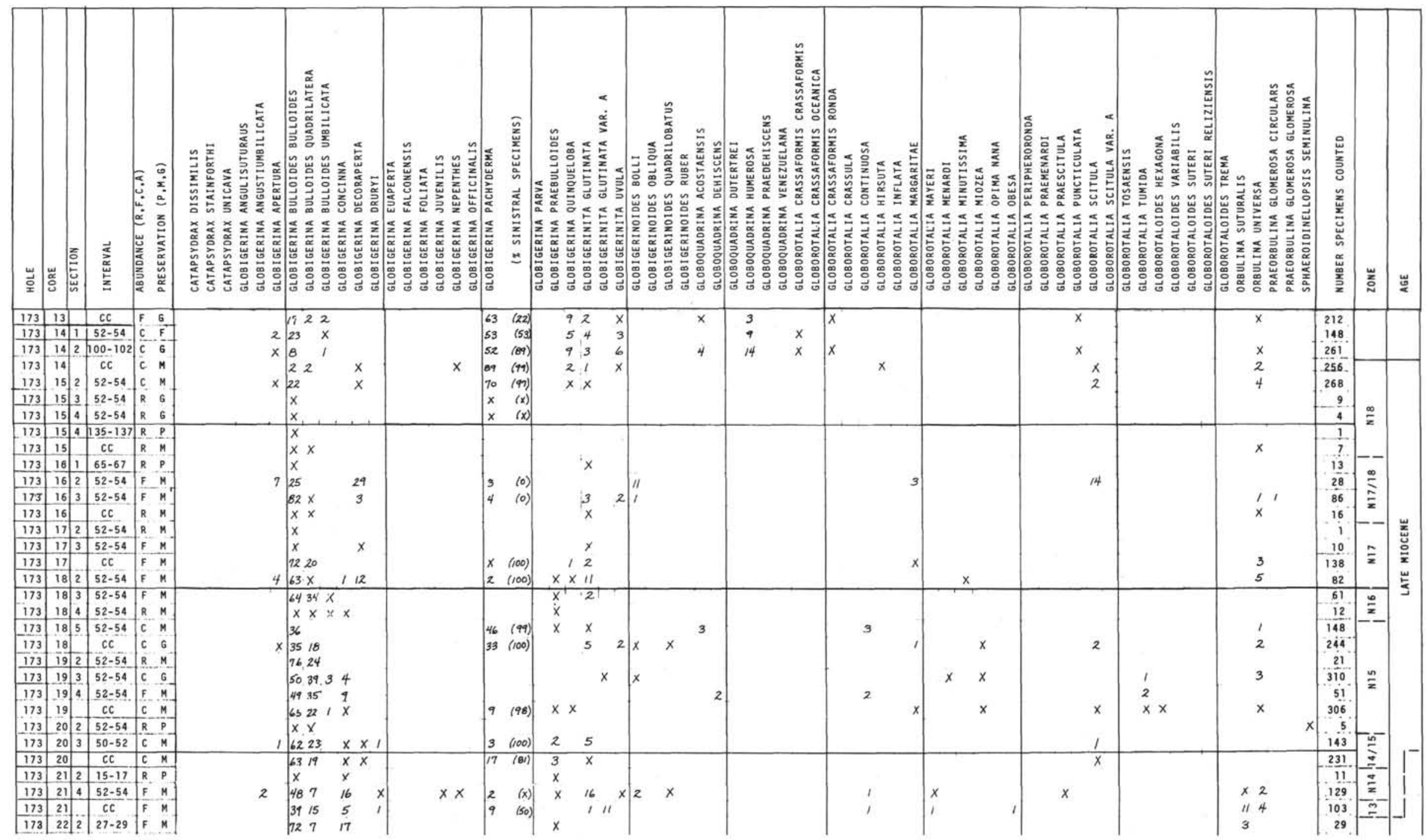




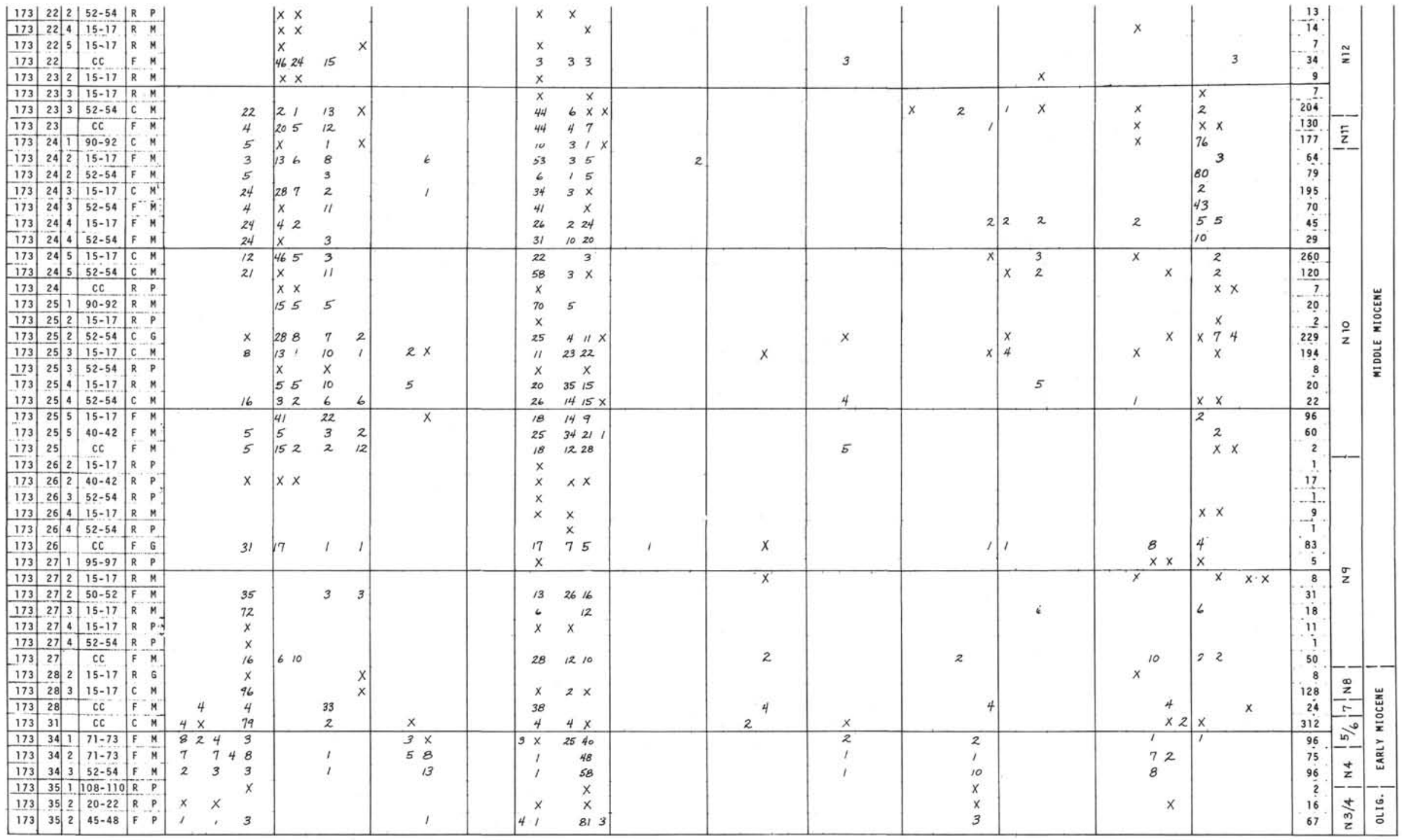

*Species abundance is recorded as percent of total planktonic specimens counted where $X=1$ ess than $1 x$; percentages were not calculated for samples containing less than 20 specimens and $X$ simply denotes species presence in these samples. 
TABLE 7 - Continued

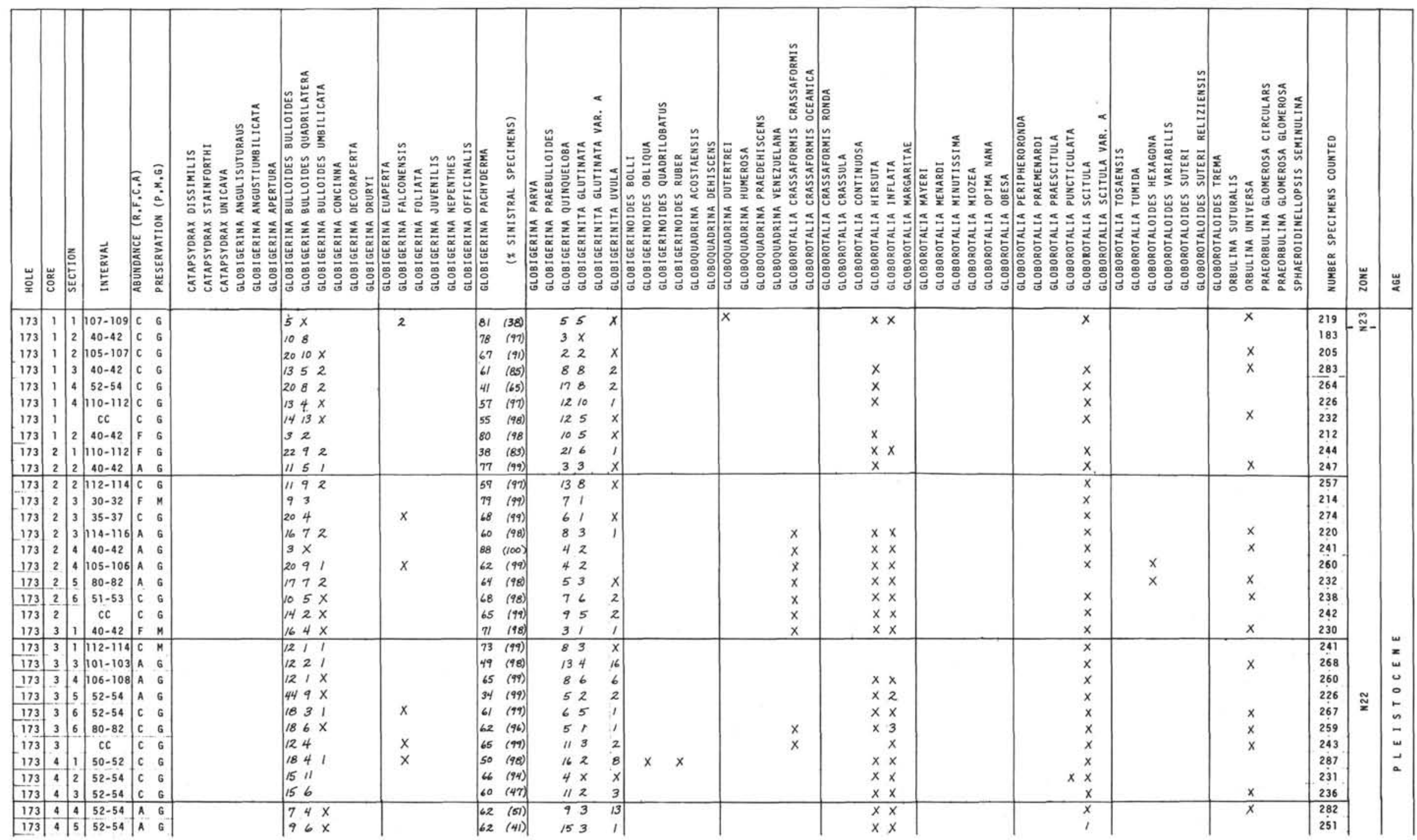




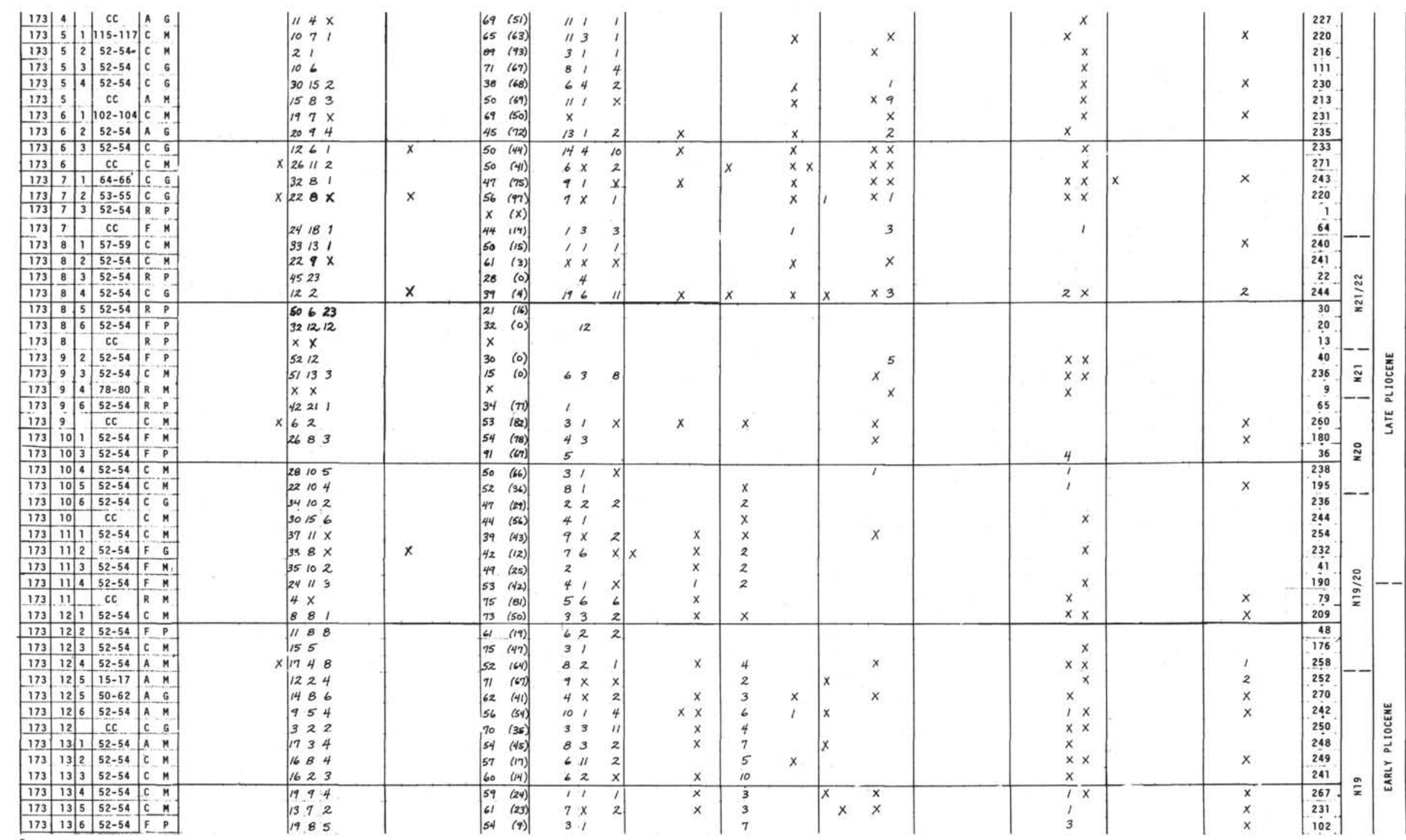

$a_{\text {Species abundance is recordo }}$

1985

presence in these samples. 


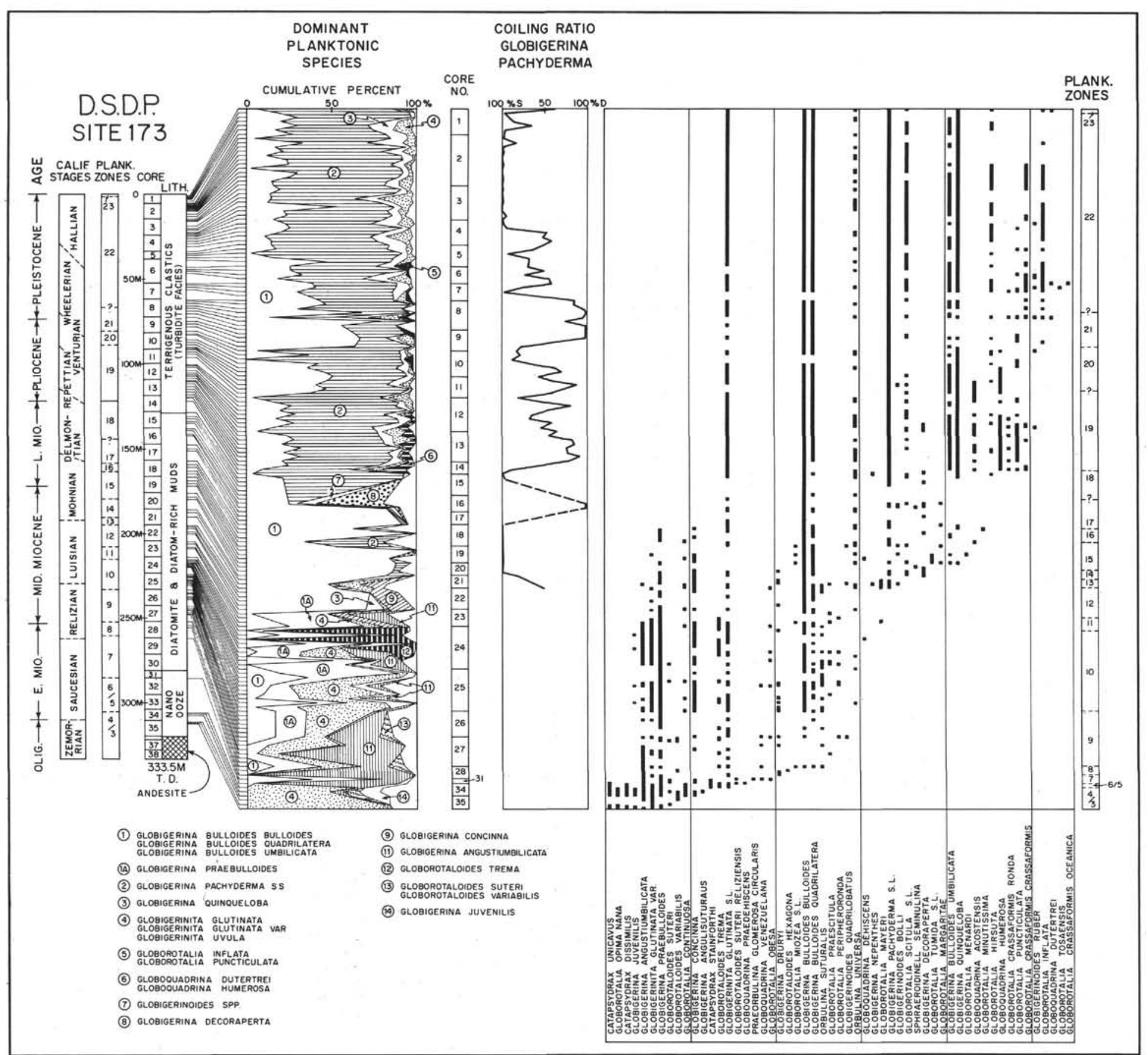

Figure 3. Stratigraphic variation of dominant planktonic species and ranges of selected planktonic species, Site 173. 
Globoquadrina dutertrei, and Globorotalia inflata mark an interval of increased but oscillating surface temperatures correlative with the lower portion of the glacial Pleistocene interval as defined by ice-rafted detritus in the North Pacific (Kent et al., 1971). The base of this interval is marked by a sharp but brief cold event in Core 7 (as sensed by an exclusively sinistral-coiling population of Globigerina pachyderma) and is approximately equivalent with a radiometric-paleomagnetic age of 1.2 m.y. B.P. according to these same authors.

The pre-glacial early Pleistocene is represented by the appearance of dominantly to exclusively dextral-coiling populations of Globigerina pachyderma and the migration into this area of significant populations of the warm temperate or transitional water mass species Globorotalia inflata (Figure 3) along with the common appearance of Globorotalia crassaformis s.s. This major biofacies change is interpreted as representing an increase in surface temperature from $10^{\circ} \mathrm{C}$ during the lower glacial Pleistocene (Cores $47)$ to a maximum of $20^{\circ} \mathrm{C}$ during the interval encompassing the Plio-Pleistocene boundary. The abundance of Globigerina bulloides also increases within this interval coincident with a decrease in the abundance of $G$. pachyderma in sympathy with increasing surface temperatures.

Globoratalia truncatulinoides ${ }^{9}$ was not found in PlioPleistocene sediments at Site 173, however, an isolated specimen of G. tosaensis was recovered in the top of Core 7 $(53.5 \mathrm{~m})$ within the later phase of the major warmtemperate to subtropical climatic event coincident with this epoch boundary at Site 173 as defined on the basis of radiolarian zonation. The absence of the zonal index precludes precise placement of the boundary between zones N. 22 and N. 21 at Site 173 in the sense of Blow (1969) and Berggren $(1969 ; 1972)$, although correlation with the paleomagnetically dated climatic oscillations recorded in the North Pacific (Kent et al., 1971) together with the isolated occurrence of Globoratalia tosaensis indicates that it occurs within Cores 7 to 8 . Moreover, correlation of the major warm event marking this interval can be made with a similar sequence recorded at Site 36 (Olsson, 1971) northeast of Site 173 where Globorotalia truncatulinoides occurs rarely along with $G$. tosaensis during the later phase of this climatic event essentially equivalent to the stratigraphic position of the isolated occurrence of $G$. tosaensis at Site 173. Additional evidence of the coincidence of a major increase in surface temperature within the California Current system during the interval encompassing the Plio-Pleistocene boundary is recorded in southern California where Globorotalia truncatulinoides constitutes a rare member of a warm temperate biofacies within the Newport Bay section (Ingle, 1967; 1972).

\section{Pliocene (Zones N. 21 to N. 19)}

Pliocene planktonic faunas are found in Cores 8 through 14 with the base of the Pliocene equated with the base of

\footnotetext{
${ }^{9}$ Recent evidence (Theyer, 1973) has cast doubt on the reliability of the Globorotalia truncatulinoides - G. tosaensis lineage as a valid index to the boundary between zones N. 22 and N. 21, at least in the South Pacific.
}

zone N. 19 at 122 meters (Core 14). Globigerina pachyderma and $G$. bulloides continue to dominate Pliocene faunas at Site 173 (Figure 3). The boundary between zones N. 21 and N. 20 cannot be located precisely in the absence of the defining taxa. However, a significant interval of reduced surface temperature characterized by sinistralcoiling populations of Globigerina pachyderma at the base of Core 9 and the top of Core 10 is thought to correlate with a similar biofacies recorded in the provincial midPliocene of southern California (Bandy, 1960; 1972; Ingle, 1967) the base of which is currently correlated with the base of zone N. 21 (Bandy et al., 1971).

Dominantly dextral but variable coiling populations of Globigerina pachyderma occur during the remainder of the Pliocene interval at Site 173 with a major increase in the abundance of Globoquadrina humerosa along with significant numbers of Globorotalia puncticulata, G. crassaformis, s.s., G. crassaformis oceanica, G. crassula, and Globigerina decoraperta marking zone N. 19 and the early Pliocene in Cores 12 through 14 . This latter biofacies represents a period of warm temperate to subtropical surface temperatures as high as $20^{\circ} \mathrm{C}$ based on analogy with the distribution of related species in the marginal northeastern Pacific (Bradshaw, 1959; Ingle, 1967). The northward migration of the $20^{\circ} \mathrm{C}$ isotherm to latitude $40^{\circ} \mathrm{N}$ during the early Pliocene (zone N. 19) represents a major and sustained climatic event previously noted within surface sections along the Pacific Coast of North America (Ingle, 1967; 1968), including the Mohole cores (Bandy and Ingle, 1970). Evidence at Site 177 off Vancouver Island and at Site 178 in the Gulf of Alaska indicates this same event was probably sensed within the Alaskan Current gyre as well as throughout the California Current system and thus constitutes a major, widespread, and easily recognized biostratigraphic interval. This same event is also marked at more southern localities by high abundances of the Globorotalia inflata-puncticulata complex along with significant abundances of the Globoquadrina dutertrei-humerosa complex indicating northward adjustment of the mixing zone between the distal portion of the California Current and the equatorial water mass to the south.

The zone N. 21-19 interval at Site 173 also encompasses the transition from populations of morphotypes referable to Globorotalia puncticulata (Zone N. 19) to populations dominated by forms referrable to $G$. inflata with the lowest appearance of $G$. inflata s.s. occurring in Core 9 within a fauna assigned to zone N. 21.

The Miocene-Pliocene boundary is herein placed at the lowest stratigraphic occurrence of Globorotalia puncticulata correlated with the base of zone N. 19 in Core 14 $(122 \mathrm{~m})$. Other workers place this epoch boundary within the top of zone N. 18 (Blow, 1969; Berggren, 1969, 1972) on the basis of the first occurrence of Sphaeroidinella dehiscens within the Pliocene (Zanclian) of Sicily (Blow, 1969). However, the first occurrence of Sphaeroidinella dehiscens, an associated major faunal break, and a paleoclimatic event appear correlative with the lowest occurrence of the Globoborotalia puncticulata-inflata complex within the North Pacific (Ingle, 1967; Bandy and Ingle, 1970; Ikebe et al., 1972) forming an easily recognized datum surface and a more convenient, if not legally correct, epoch boundary. Still others place this boundary at the base of 
zone N. 18 on the basis of correlations with the base of the Tabianian (type lower Pliocene) of northern Italy and correlations of faunal events and paleomagnetic stratigraphy in the equatorial Pacific (Burkle, 1971). This latter view is currently favored by diatom specialists (see Schrader, Chapter 17, this volume) leading to a discrepancy in the placement of this epoch boundary based on the two zonations, a common but not easily resolved biostratigraphic problem.

\section{Late Miocene (Zones N. 18-N. 15)}

Late Miocene planktonic faunas are dominated by Globigerina bulloides s.l. and G. pachyderma with the exception of a significant incursion of an unusual warmtemperate to subtropical biofacies in the younger portion of this interval.

An abrupt decrease in surface temperature occurs during the latest Miocene (uppermost zone N. 18) as expressed by the relatively brief occurrence of sinistral-coiling populations of Globigerina pachyderma s.l. in Cores 14 and 15 $(122-131 \mathrm{~m})$ in contrast to the subtropical temperatures prevailing during the early Pliocene. The later portion of this same paleo-oceanographic event is also recorded at the top of the Pullen Formation at the base of the Centerville Beach section in northern California (Ingle, 1968), again emphasizing the direct correlation of this land-based section with the Pliocene and Pleistocene interval at Site 173. Rare occurrences of Globigerina decoraperta and $G$. nepenthes appear within this interval, and the fauna is correlated with zone N. 18 principally on the basis of superposition and correlation with an equivalent interval in the Mohole cores containing the zonal markers (Bandy, 1971). The boundary between zones N. 17 and 18 is probably encompased within the lower portion of this subarctic biofacies. Interestingly, this brief cool event is not sensed in upper Miocene sediments south of Cape Mendocino, suggesting that the $5^{\circ}$ isotherm did not penetrate much farther south than this latitude.

A significant incursion of an unusual subtropical biofacies appears just prior to the latest Miocene cool event and is best developed in Core $16(140-142 \mathrm{~m})$. The fauna characterizing this interval is dominated by forms referrable to Globigerina decoraperta in addition to $G$. bulloides s.l. and Globigerinoides bolli, with rare occurrences of Globorotalia margaritae and Sphaeroidinellopsis seminulina. Unfortunately, sparse faunas immediately above and below this biofacies prevent a precise definition of the duration of this important paleo-oceanographic event. Nevertheless, this same northward migration of the $20^{\circ} \mathrm{C}$ isotherm is recorded by planktonic foraminifera (Ingle, 1967) and Radiolaria (Casey, 1972) in surface sections assigned to the Delmontian Stage of Kleinpell (1938) in southern California indicating the regional nature of this particular climatic event.

A major late Miocene interval of cool-temperate to subarctic surface temperature is recorded in Cores 18 through $20(157.5-186 \mathrm{~m})$ as defined by exclusively sinistral-coiling populations of Globigerina pachyderma s.l. High abundances of this latter species dominate faunas during the most intense phase of this event, whereas $G$. bulloides is the predominate species present during waxing and waning phases. This same event is clearly recorded in upper Miocene sediments assigned to the Mohnian Stage in southern California (Ingle, 1963, 1967, 1972). In fact, the southward migration of subarctic and cool-temperate isotherms within the California Current occurred to at least latitude $28^{\circ} 59^{\prime} \mathrm{N}$ in the marginal eastern North Pacific in the vicinity of the Mohole (Parker, 1964; Bandy and Ingle, 1970). The appearance of this subarctic biofacies is also recorded in the Miocene-Pliocene Yakataga Formation of Alaska (Bandy et al., 1969), as well as the Miocene of New Zealand (Kennett, 1968a), and the Sea of Japan (Asano et al., 1969). This global paleo-oceanographic-paleoclimatic event represents a response to an intense period of polar refrigeration which occurred simultaneously in the Antarctic and Arctic areas driving cooler isotherms toward the equator and resulting in two widespread and unusually well defined planktonic datums correlative with the initiation and termination of this event.

The interval encompassing the major late Miocene cold event apparently spans zones N. 17 to just below the base of zone N. 15 at Site 173 similar to its appearance elsewhere (Bandy et al., 1971). The base of zone N. 17 at Site 173 is placed at the stratigraphically youngest appearance of Globigerina praebulloides (Core 18;159.5 m), whereas the boundary between zones N. 16 and N. 15 is placed at the stratigraphically highest appearance of Globorotalia continuosa and stratigraphically lowest appearance of Globoquadrina acostaensis (Core 18;164 m). The earliest dominantly sinistral population of Globigerina pachyderma s.l. occurs at 186 meters (Core 20) within zone 14.

It should be noted that placement of the middle Miocene-upper Miocene boundary in this report follows Blow (1969) and others who equate this boundary with zone N. 15 (Berggren, 1971, 1972) and the more traditional view of the division of the Miocene. Alternately, Bandy (1964, 1972) and Bandy and Ingle (1970) have placed this boundary between zones N. 12 and N. 13 approximately equivalent with the first evolutionary occurrence of Globigerina pachyderma and retaining the Mohnian Stage of California wholly within the upper Miocene.

\section{Middle Miocene (Zones N. 15 - N. 9)}

The middle Miocene interval encompasses several major changes in dominant planktonic foraminiferal biofacies at Site 173 duplicating similar trends established in lower Mohnian, Luisian, and Relizian age sediments exposed in the Coast Ranges of California.

The late Miocene-middle Miocene boundary is placed near the top of zone N. 15 just below the stratigraphically lowest occurrence of Globoquadrina acostaensis (Core 18; $164 \mathrm{~m}$ ) and coincident with the youngest occurrence of Globorotalia continuosa. The boundary between zones N. 15 and N. 14 is placed at the youngest occurrence of Globigerina druyi (Core 20;180 m). Globigerina apertura, G. quinqueloba, Globorotalia margaritae, G. scitula s.s., and Sphaeroidinellopsis seminulina all make their stratigraphically oldest appearances within the Zone N. 15 interval at Site 173. Globigerinoides quadrilobatus, Globoquadrina dehiscens, and Globorotalia miozea appear briefly within zone 15 whereas $G$. tumida and $G$. menardi s.l. make their 
only appearance at Site 173 within this zone, emphasizing the fleeting nature of tropical taxa at this latitude.

The boundary between zones N. 14 and N. 13 is placed at the oldest occurrence of Globigerina decoraperta and the youngest appearance of Globorotalia mayeri (Core 21; $195.5 \mathrm{~m}$ ). The stratigraphically highest appearances of Globigerina angustiumbilicata, Globorotalia praescitula, and Orbulina suturalis occur within this zone as defined at Site 173. The stratigraphically oldest occurrence of Globigerina pachyderma s.l. takes place in Core $21(195.5 \mathrm{~m})$ and is correlated with the approximate boundary between zones N. 13 and N. 12 at the top of the Luisian Stage in California (Ingle, 1967; Bandy and Ingle, 1970) and in the Mohole cores (Bandy, 1972). This species is also reported as first appearing within the zone N. 12-13 interval in Japan (Ikebe et al., 1972).

A major change in composition of the dominant planktonic biofacies occurs at the top of Core 21 where the dominant members are Globigerina bulloides and $G$. concinna rather than the more modern faunas encountered above this level. These two taxa are thought to be indicative of warm-temperate surface temperatures near $15^{\circ} \mathrm{C}$ as indicated by the marginal appearances of subtropicaltropical elements noted above. This same biofacies with scattered occurrences of subtropical-tropical taxa occurs within Luisian sediments exposed at Newport Bay in southern California (Lipps, 1964; Ingle, 1972) and with an even larger compliment of tropical elements in the Mohole cores (Parker, 1964; Bandy and Ingle, 1970).

The approximate boundary between zones 11 and 12 is correlated with the youngest appearance of Globorotalia peripheroronda at Site 173 (Core 23;208.5 m) and as noted in other temperate areas (Bandy and Ingle, 1970; Ikebe et al., 1972). The stratigraphically youngest appearance of Globorotaloides trema also occurs within zone N. 12 as defined at Site 173. Finally, the transition from Globigerina bulloides s.l. to G. praebulloides occurs within this same zone along with the youngest occurrence of a fauna partially dominated by Globigerina angustiumbilicata (Figure 3).

A strikingly unusual biofacies composed of up to 80 per cent Globorotaloides trema occurs briefly within Core 24 $(215.5$ to $219 \mathrm{~m})$ along with admixtures of Globigerina praebulloides and $G$. angustiumbilicata and the youngest occurrences of Globorotaloides suteri reliziensis. This same biofacies appears briefly in the Mohole cores off Baja California (Bandy and Ingle, 1970), where it is coincident in part with the earliest occurrence of Globorotalia praefosh $i$ and the oldest occurrence of $G$. peripheroacuta, in turn correlated with the base of zone N.11. Thus, the boundary between zones N. 10 and N. 11 is placed at 215.5 meters in Core 24 at Site 173. Early middle Miocene and early Miocene faunas within zone N. 10 through N. 5 are characterized by a biofacies dominated by Globigerina praebulloides, Globigerinita uvula (and varieties), and increasing abundance of Globigerina angustiumbilicata (Figure 3) representing cool surface temperatures oscillating between $10^{\circ}$ and $15^{\circ} \mathrm{C}$. This same biofacies is known to be characteristic of part or all of this same interval in other temperate areas of the Pacific including Japan (Asano et al., 1968), where it is accompanied by Globorotalia peripheroronda and $G$. praescitula. More specifically, this biofacies is abundantly represented within bathyal sediments assigned to the Relizian and Saucesian stages of California (Bandy and Ingle, 1970). Early and mid-Miocene planktonic faunas recorded in northern Europe are also dominated by a similar species group (Jenkins, 1966) symptomatic of cooler surface temperatures in that region.

Although more exotic members of the Globorotalia fohsi lineage are absent at Site 173, members of the Orbulina lineage are persistently present. The top of zone N. 9 is arbitrarily picked at the stratigraphically lowest occurrence of Orbulina universa ${ }^{10}$ s.s. (Core $25 ; 233.5 \mathrm{~m}$ ) in the absence of other zonal markers, whereas the base of zone N. 9 is placed at the lowest occurrence of Orbulina suturalis (Core $27 ; 252.5 \mathrm{~m}$ ) representing the widely recog. nized Orbulina datum surface (sensu Blow, 1969, p. 231) separating the middle Miocene from the early Miocene interval.

The genus Orbulina has not been reported from rocks dated older than Luisian age in California although it has been suggested that this genus first occurs in rocks equivalent in age to the Relizian at lower latitudes (Bandy, 1966; Bandy and Ingle, 1970). The occurrence of Orbulina suturalis at Site 173, together with the Globigerina angustiumbilicata biofacies characteristic of Relizian age sediments in California, provides clear evidence that this critical morphotype does indeed occur for the first time within the middle or lower Relizian stage. Interestingly, correlations of this interval via calcareous nannoplankton anticipated that this datum surface might well occur within the Relizian Stage as noted by Berggren (1972).

Radiometric ages from several areas suggest the Orbulina datum surface (base zone N.9) is equivalent to 15.5 to 16.00 m.y. B.P. (Berggren, 1972). Turner (1970) has recently provided a radiometric date of 15.3 m.y. B.P. for the base of the Relizian Stage in California, which may in turn indicate that the initial appearance of orbulines is actually closer to 15.5 or 15.0 m.y. B.P. as supported by various radiometric dates recently presented from Japan (Ikebe et al., 1972).

\section{Early Miocene (Zone N. 8 - N. 4)}

Although Orbulina suturalis clearly marks the zone N. 9-N. 8 (Core $27 ; 252.5 \mathrm{~m}$ ) boundary at Site 173 , lack of an equally definitive index precludes the recognition of the zone N. 8-N. 7 boundary. Core 28 (252.5-262 m) contains only sparse foraminifera and Cores 29 and 30 are barren of planktonic foraminifera, adding to this problem. Nevertheless, the mid-portion of zone N. 7 is tentatively equated with the youngest appearance of Catapsydrax stainforthi and the stratigraphically lowest occurrence of Praeorbulina glomerosa circularis in Core $28(262 \mathrm{~m})$ near the base of the lengthy interval of diatom-rich sediment.

The top of zone 6 is placed at the stratigraphically highest occurrence of Catapsydrax dissimilis in Core 31 $(285.5 \mathrm{~m})$ within the nannofossil ooze representing initial marine deposition at this site. These faunas allow direct

\footnotetext{
${ }^{10}$ The simultaneous vs. separate appearances of Orbulina suteralis and $O$. universa morphotypes in time is disputed as is the possible polyphyletic origin of this "genus" (Parker, 1962; Bandy et al., 1969).
} 
correlation of this portion of the column at Site 173 with the Saucesian Stage of California in which Bandy et al., $(1969)^{11}$ have reported the same zonal indices.

Although the boundary between zone N. 6 and N. 5 is indefinite, a final prominent biofacies change occurs within the zone N. 6-N. 5 interval (Core 31) where Globigerina praebulloides represents simply an accessory species within a fauna dominated by Globigerinita glutinata (and varieties) and Globigerina juvenilis in contrast to its later dominance within the early middle Miocene.

Cores 32 and 33 (285.5 to $304.5 \mathrm{~m}$ ) are barren of planktonic foraminifera with the top of zone N. 4 placed at the stratigraphically lowest occurrence of Catapsydrax stainforthi in Core $34(305.5 \mathrm{~m})$. The mid-portion of zone N. 4 if correlated with the youngest occurrence of Globigerina angulisuturalis at a lower horizon in Core 34 (306.7 m). Catapsydrax unicavus, Globigerina parva, and Globorotalia opima nana are all restricted in their range to Cores 34 and 35, with Globorotaloides trema making its earliest appearance at the top of this interval (Core 34; $305.2 \mathrm{~m})$.

\section{Late Oligocene (Undifferentiated Zones N. 4 - N. 3)}

The oldest planktonic foraminiferal faunas recovered at Site 173 occur in Core 35 (311.5-311.9 m) and are sparse and poorly preserved. Faunas in Core 35 are characterized by high abundances of a variety of Globigerinita glutinata with minor occurrences of Catapsydrax dissimilis, $C$. unicavus, Globigerina juvenilis, G. parva, G. praebulloides, Globigerinita uvula, Globorotalia opima nana, and Globorotaloides suteri. This group of species ranges across the zone N. 4-N. 3 boundary and consequently is included within an undifferentiated N. 4-N. 3 interval. However, the calcareous nannofossil Triquetrorhabdulus carinatus is present within the 306 to 320 meter interval (Cores 34 and 35), and common specimens of Reticulofenestra bisecta occur within the 312 to 320 meter interval (Core 35), clearly indicating that sediments below 312 meters are Oligocene in age and equivalent to Zone N. 3.

\section{Benthonic Foraminifera and Paleobathymetry}

The generally well preserved and common benthonic foraminifera recovered at Site 173 exhibit a remarkable similarity considering the late Pleistocene-late Oligocene interval represented in this hole. The majority of benthonic species present are common to lower middle bathyal and lower bathyal depths and include Melonis pompilioides, $M$. barleeanus, Gyroidina soldani, Uvigerina senticosa, Pleurostomella alternans, P. elliptica, Pullenia bulloides, Hoeglundina elegans, Bulimina rostrata, Stilostomella lepidula, and Oridorsalis umbonatus. All of these species and others (Table 8) are indicative of Recent benthonic faunas found at depths between 2500 and 3500 meters in the eastern North Pacific. Admixtures of species displaced from shallower middle and upper bathyal depths are also present and include Bulimina striata mexicana, Uvigerina peregrina

\footnotetext{
${ }^{11}$ The sediments from which Bandy et al. (1969) obtained these faunas have been variously assigned to the upper Saucesian and lower Relizian stages (Lipps and Kalisky, 1972).
}

TABLE 8

Benthonic Foraminifera Identified at Site 173

Astacolus sp.

Bolivina subreticulata Parr

Bulimina rostrata $\mathrm{H}$. B. Brady

Bulimina striata d'Orbigny var. mexicana Cushman

Bulimina subcalva Cushman and Stewart

Buliminella subfusiformis Cushman

Cassidulina minuta Cushman

Cassidulina subglobosa Brady

Chilostomella czizeki Reuss

Chilostomella oolina Schwager

Chilostomella ovoidae Reuss

Cibicides bradyi (Trauth)

Cibicides rugosus (Phleger and Parker)

Cibicides spiralis Natland

Cibicides wullerstorfi (Schwager)

Eggerella bradyi (Cushman)

Ehrenbergina bradyi Cushman

Ehrenbergina compressa Cushman

Eilohedra Levicula (Resig)

Epistominella capitanensis (Cushman and Kleinpell)

Epistominella exigua (Brady)

Epistominella pacifica (Cushman)

Epistominella subperuviana (Cushman)

Fissurina carteri

Fissurina subformosa

Glandulina laevigata d'Orbigny

Globobulimina affinis (d'Orbigny)

Globobulimina ovula (d'Orbigny)

Globobulimina pacifica Cushman

Globobulimina pseudoaffinis (Kleinpell)

Gyroidina gemma Bandy

Gyroidina relizana Kleinpell $^{\mathrm{b}}$

Gyroidina soldani d'Orbigny

Gyroidina turgida (Phleger and Parker)

Gyroidina zealandica Finlay

Hoeglundina elegans (d'Orbigny)

Karrariella bradyi (Cushman)

Lagena striata (d'Orbigny)

Laticarinata pauperata (Parker and Jones)

Martinotiella communis (d'Orbigny)

Melonis barleeanus (Williamson)

Melonis pompilioides (Fichtell and Moll)

Oridorsalis umbonatus (Reuss)

Planulina baggi Kleinpell

Planulina ornata (d'Orbigny)

Plectofrondicularia advena (Cushman)

Pleurostomella alternans Schwager

Pleurostomella elliptica Galloway and Heminway

Pullenia bulloides (d'Orbigny)

Pullenia miocenica Kleinpell

Pullenia quinqueloba (Reuss)

Pyrgo murrhina (Schwager)

Pyrgo serrata (W. L. Bailey)

Sigmoilina sp.

Rectouvigerina (Siphogenerina) kleinpelli $(\text { Cushman })^{c}$

Rectouvigerina (Siphogenerina) Smithi (Kleinpell) ${ }^{\mathrm{d}}$

Sphaeroidina bulloides d'Orbigny

Stainforthia nodosa (R. E. and K. C. Stewart)

Stilostomella lepidula (Schwager)

Stilostomella spimea (Cushman)

Uvigerina auberiana d'Orbigny

Uvigerina gallowayi Cushman ${ }^{c}$

Uvigerina hispida Cushman

Uvigerina peregrina dirupta Todd

Uvigerina proboscidea Schwager

Uvigerina senticosa Cushman

Uvigerina striatella

Valvulineria araucana (d'Orbigny)

Valvulineria araucana (d'Orbigny) var. malagaensis Kleinpell

Valvulineria californica Cushman ${ }^{\mathrm{a}}$ 
TABLE 8 - Continued

andicative of the Luisian Stage of the California Miocene (Kleinpell, 1938).

Indicative of the Relizian Stage of Kleinpell (1938).

Indicative of the Saucesian Stage of Kleinpell (1938).

dindicative of the Zemmorian Stage of Kleinpell (1938).

derupta, $U$. hispido costata, Globogulimina affinis, and Epistominella pacifica suggesting slow but persistent downslope movement of material.

Benthonic faunas were not subjected to quantitative analysis, but qualitative data suggest percentages of displaced species are highest in the early Miocene-later Oligocene interval. Perhaps one of the most significant aspects of the benthonic faunas at this site is the general absence of displaced littoral and shelf-depth species. All of the faunas encountered are indicative of an outer slope environment a significant distance from the shelf and main avenues of downslope transport. Considering that the accumulation of sediment penetrated at this site was originally assumed to represent a submarine fan, the lack of displaced shallow-water benthonic species is even more significant. The faunas present at Site 173 are not representative of a proximal deep-sea fan environment.

Although benthonic faunas at Site 173 were not scrutinized as closely as planktonic species, several age diagnostic species of benthonic foraminifera were recovered. A quantitative analysis of these faunas would very likely yield many more. One specimen of Valvulineria californica, an index to the Luisian Stage of California (Kleinpell, 1938), was found in Core $23(210 \mathrm{~m})$ within an interval correlated with the Luisian Stage on the basis of planktonic species (Figure 3 ). In addition, a single specimen of Gyroidina reliziensis, indicative of the Relizian Stage, was recovered in Core $27(250 \mathrm{~m})$ within an interval equated with the Relizian on the basis of planktonic species. Moreover, rare specimens of Uvigerina gallowayi and Rectouvigerina ("Siphogenerina") kleinpelli, indicative of the Saucesian Stage of California, were found in Core 28 $(262 \mathrm{~m})$ and correlated with the Relizian-Saucesian boundary. Finally, Rectouvigerina ("Siphogenerina") smithi, common in the Zemorrian Stage of California, was found in Core $35(312 \mathrm{~m})$ within sediments dated as latest Oligocene on the basis of both calcareous nannoplankton and planktonic foraminifera and correlated with the Zemorrian Stage on this basis (Figure 3). Further study of the benthonic faunas at Site 173 would likely prove most instructive in terms of assisting in correlation with the benthonic foraminiferal stages of California (Kleinpell, 1938; Natland, 1957) and with the interpretation of changes in rates of deposition and/or subsidence in this area.

\section{SITE 174}

\section{Geologic and Stratigraphic Setting}

Site 174 is located on the distal portion of Astoria Submarine Fan, a major cone of clastic debris which lies westward of the mouth of the Columbia River at the base of the continental slope (Figure 1). Scientific objectives at this site included (a) determination of the age of the fan by dating the acoustic discontinuity upon which the fan sediments rest and (b) scrutiny of variations in depositional events and mineralogy through the fan sequence as an aid to interpretation of tectonic processes at the continental margin. Drilling in Holes 174 and $174 \mathrm{~A}$ penetrated a sequence of 284 meters of thick Pleistocene turbidite sands and silts (Astoria Fan) underlain by 595 meters of Pleistocene and Pliocene thin-bedded silt turbidites and muds interpreted as abyssal plain deposits. Most of the Pleistocene sediment in this sequence is thought to have been derived within the Colombia River drainage system and ultimately funneled onto the fan via Astoria Submarine Canyon (Nelson, 1968; Duncan, 1968). However, mineralogical studies demonstrate that sediment deposited prior to $1.5 \mathrm{~m} . \mathrm{y}$. ago $(370-879 \mathrm{~m})$ was derived from sources north or south of the present Columbia River source (Scheidder et al., Chapter 25).

\section{Abundance and Preservation of Foraminifera}

Well to moderately well preserved planktonic and benthonic foraminifera are common throughout the sequences cored at Site 174 (Tables 4 and 9), however, absolute abundance varies widely as a function of the depositional processes active on the fan and underlying abyssal plain environment. Rapidly deposited turbidite sand intervals contain only rare specimens of benthonic species and are almost barren of planktonic specimens due to dilution by sand. Alternately planktonic specimens are most abundant in silt-rich intervals and are especially common within the upper subunits of graded turbidite intervals where they were apparently deposited during the waning phases of individual flows across the fan and plain.

\section{Planktonic Foraminifera, Age, and Paleo-oceanography}

Pleistocene planktonic foraminiferal faunas are present in Cores 1 through $3(0-19.5 \mathrm{~m})$ of Hole 174 and Cores 1 through 35 ( 28 to $417.5 \mathrm{~m}$ ) of Hole 174A. Quantitative analysis of these faunas (Table 9; Figure 4) reveals that individual assemblages within this interval are dominated by sinistral-coiling populations of Globigerina pachyderma and variable but significant populations of Globigerina bulloides bulloides, $G$. bulloides quadrilatera, $G$. bulloides umbilicata, and $G$. quinqueloba along with minor percentages of Globigerinita glutinata, G. uvula, Globorotalia scitula, and Orbulina universa. This limited group of species is characteristic of the cooler portions of the California Current system north of latitude $35^{\circ} \mathrm{N}$ today (Bradshaw, 1959) as well as during the Pleistocene (Bandy, 1967; Kheradpir, 1970; Morin, 1971) and significant intervals within the later Miocene and Pliocene (Ingle, 1967; Bandy and Ingle, 1970).

Coiling ratios among populations of Globigerina pachyderma were again utilized to aid in identifying intervals of relatively warm and cool surface temperature within the Pleistocene and Pliocene sediments encountered at Site 174 as discussed for Site 173 . Exclusively sinistral populations are assumed to represent minimum surface temperatures of $50^{\circ} \mathrm{C}$ whereas exclusively dextral populations are thought to be indicative of temperatures higher than $15^{\circ} \mathrm{C}$ by analogy with modern and Pleistocene distributions of this species in the marginal northeastern Pacific and elsewhere (Bandy, 1960; Ingle, 1967; Bandy, 1967; Morin, 1971; and others). 
TABLE 9

Abundance and Stratigraphic Distribution of Planktonic Foraminifera, Site $174^{\mathrm{a}}$

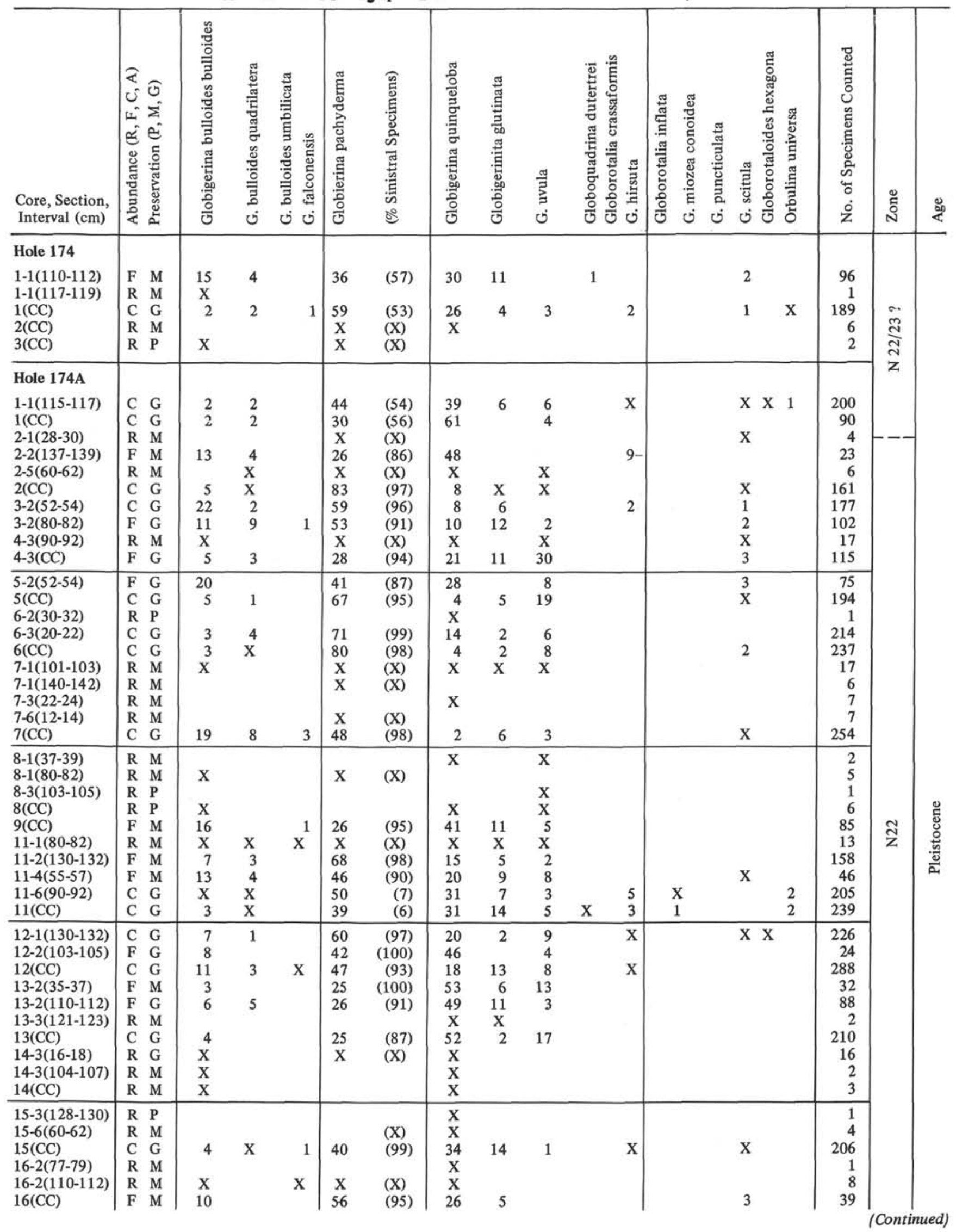


TABLE 9 - Continued

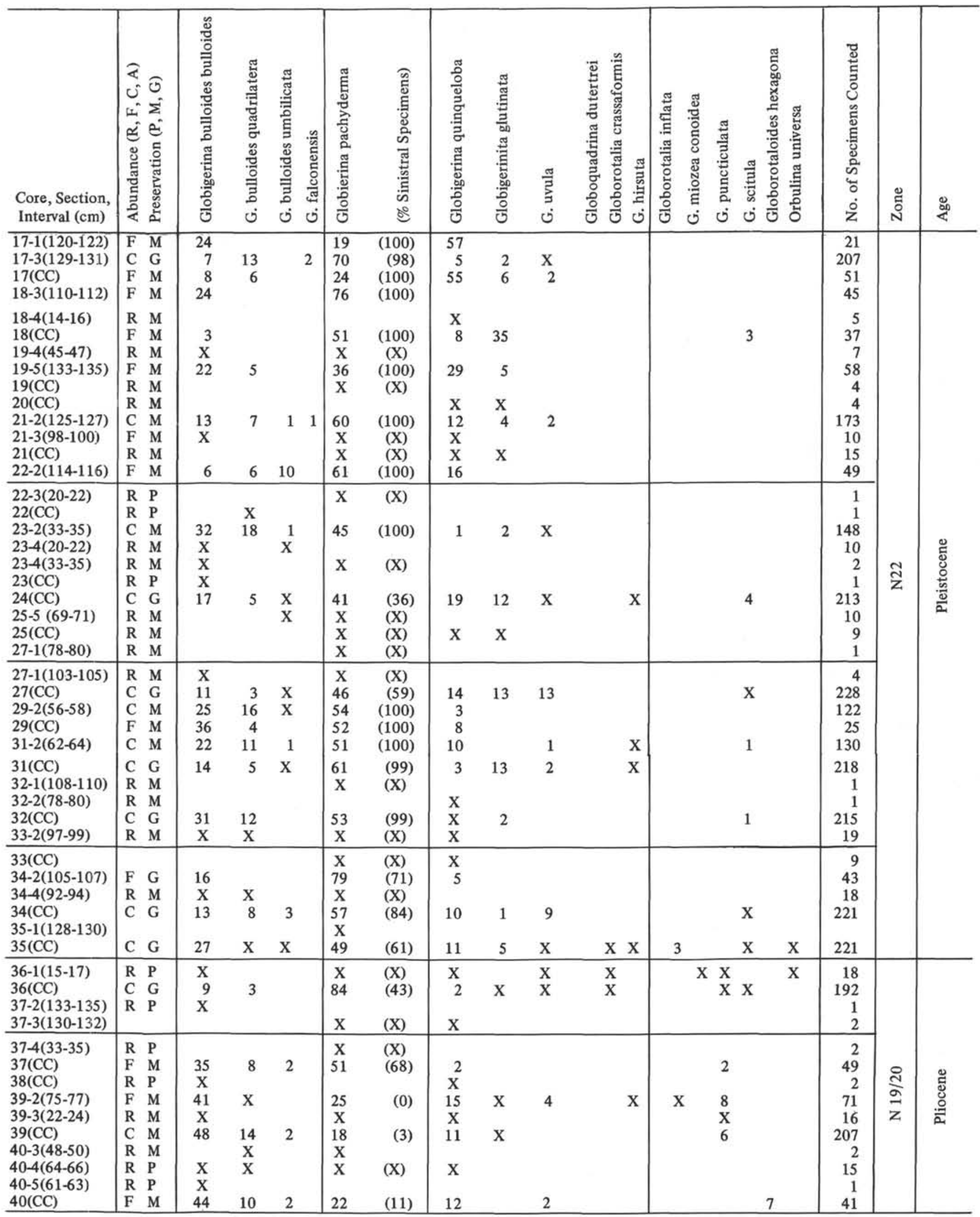

${ }^{a}$ Species abundance is recorded as percent of total planktonic specimens counted where $\mathrm{x}=1$ less than $1 \%$; percentages were not calculated for samples containing less than 20 specimens and $x$ simply denotes species presence in these samples. 
J. C. INGLE, JR.

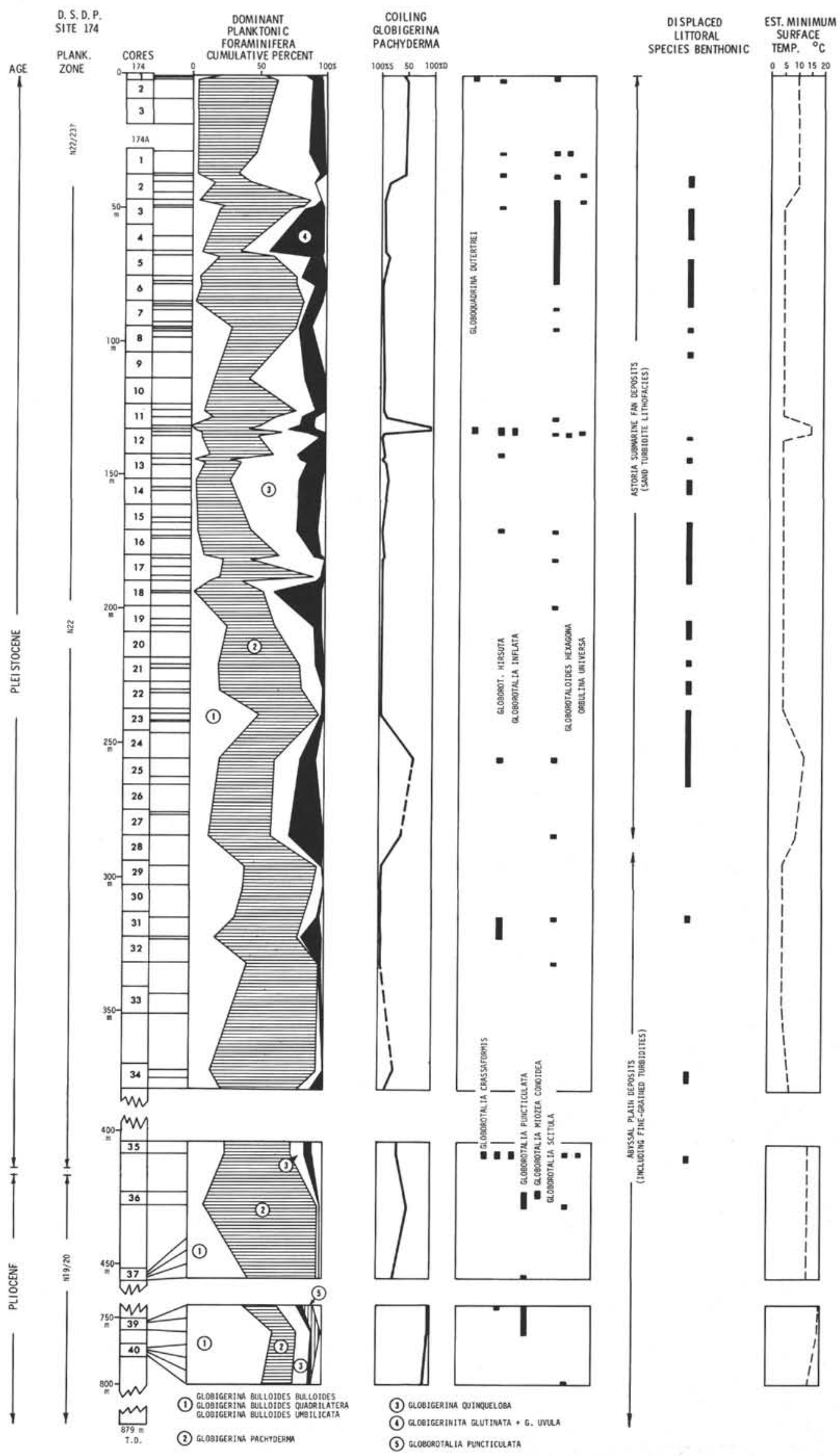

Figure 4. Stratigraphic variation of dominant planktonic species, ranges of selected planktonic species, and variation of estimated minimum surface temperatures, Site 174. 
Sediments from 0 to 37.5 meters (174-1-1, 110-112 to 174A-1, CC) at Site 174 contain mixed sinistral-dextral populations of Globigerina pachyderma and rare occurrences of Globoquadrina dutertrei, and Globorotaloides hexagona representing surface temperatures similar to those found in this area today (Figure 2). This relatively warmer interval may well correspond to the post-12,000 year B.P. interval of increased surface temperature identified in a number of Holocene-Pleistocene sequences penetrated off southern California (Bandy, 1967; Kheradpir, 1970; Morin, 1971). In light of this speculative correlation the 0 to 37.5 meter interval at Site 174 is tentatively assigned to zones N. 22/23 (?) representing the Pleistocene-Holocene transition.

The lengthy interval from 37.5 to 379.5 meters (174A-34, CC) is dominated by exclusively sinistral populations of Globigerina pachyderma representing subarctic surface temperatures correlated with zone N. 22 and a major portion of the so-called glacial Pleistocene clearly recorded at Site 173 (Figure 3) and at Site 36 southwest of Site 174 (Olsson, 1971). This sustained period of cold surface temperature is interrupted only twice. A sharp increase in surface temperature is marked by exclusively dextral populations of Globigerina pachyderma at 130 meters (Core 11), accompanied by the brief appearance of several warm temperate-subtropical water mass species, including Globorotalia inflata, G. crassaformis, Globoquadrina dutertrei, and Globorotaloides hexagona, all indicative of higher surface temperature (Figure 3). A second warming trend is indicated by mixed dextral-sinistral populations of Globigerina pachyderma within the 256 to 285 meter interval (Cores 25 to 27 ).

Samples from Core $35(403.0-417.5 \mathrm{~m})$ also contain a mixed dextral-sinistral coiling population of Globigerina pachyderma along with rare occurrences of Globorotalia crassaformis, G. inflata, and Globorotaloides hexagona and are correlated with the warmer faunas occurring near the Pliocene-Pleistocene boundary (base of zone N. 22) at Site 173 (Figure 3).

Pliocene planktonic faunas characterized by predominantly dextral populations of Globigerina pachyderma and significant occurrences of the Globorotalia puncticulata s.l. complex first occur in Core 36 (446 to $455.5 \mathrm{~m}$ ) and are also present in Cores 37, 39, and 40 (Figure 4). Accordingly, the Pliocene-Pleistocene boundary is thought to occur within the unsampled interval between Cores 35 and 36. Minor species present in Core 36 include rare but well-developed specimens of Globorotalia miozea conoidea known to range upward into zone N. 20 in California, New Zealand, and the North Atlantic, Significantly, Olsson (1971) records the extinction of this species just below the first occurrence of Globorotalia tosaensis at Site 36 located southwest of Site 174 in an area closer to the western boundary of the California Current. Thus, the first appearance of this species in Core 36 supports the placement of the Pliocene-Pleistocene boundary between Cores 35 and 36 at Site 174 and also suggests zone N. 21 is encompassed within this gap.

A warm-temperate Pliocene planktonic fauna dominated by Globigerina bulloides and significant percentages of Globorotalia puncticulata occurs in Cores 39 and 40 (Figure 4). This interval of relatively warm surface temperature and northward migration of transitional water mass species can be correlated with a portion of a lengthy early Pliocene warm event clearly recorded in both surface sections along the Pacific Coast (Ingle, 1967, 1968) and deep-sea sequences, including the Mohole (Parker, 1964; Ingle, 1967; Bandy and Ingle, 1970), Site 36 (Olsson, 1971), and at Site 173 (Figure 3).

Although a zonal assignment of N. 20 can be made with some confidence for faunas in Core 39, the lengthy unsampled interval between Cores 37 and 39 preclude a precise boundary between these two zones, and this entire interval is included conservatively within both zones (N. 19/20) pending further study.

\section{Benthonic Foraminifera and Paleobathymetry}

Rare to common specimens of species displaced from littoral and shelf depths occur throughout most of the 0 to 284 meter interval at Site 174 (Figure 4), emphasizing the shallow water origin and displaced nature of the sediments building Astoria Fan. Many of these species including Buliminella elegantissima, Buccella frigida, Elphidium clavatum, $E$. incertum, E. microgranulosum, and Nonionella miocenica stella are indicative of water depths shallower than 50 meters and comprise members of the Recent paralic foraminiferal biofacies found along the coastlines of Oregon and California (Cooper, 1961; Bandy, 1963; Manske, 1968).

There is a sharp decline in the general abundance of displaced shallow water species within the lower 284 to 879 meter interval at Site 174 (Figure 4) reflecting a major difference in style of sedimentation prior to the appearance of coarse turbidites of Astoria Fan proper. However, displaced species do continue to appear within Pliocene and early Pleistocene sediments, suggesting the older lithologic unit might be more properly viewed as representing the extreme distal portion of the Astoria Fan complex rather than an abyssal plain environment.

Interestingly, shallow water species are absent or occur only marginally within several horizons containing planktonic faunas indicative of higher surface temperature within the Pleistocene of Site 174 (Figure 4). This trend may reflect the decrease in rate of sedimentation across the shelf-slope gradient associated with eustatic rises in sea level when depositional processes active at the shelf edge move shoreward and much sediment is trapped in estuaries and lagoons. Thus, quantitative analysis of benthonic faunas in this sequence would be especially helpful in delineating discrete intervals of maximum and minimum rates of sedimentation as tuned to climatic fluctuations.

In situ lower middle bathyal and lower bathyal species, including Melonis barleeanus, M. pompilioides, Bulimina rostrata, Eggerella bradyi, and others (Table 10), occur throughout the entire sequence penetrated, indicating that deposition at this site has occurred at lower middle bathyal to lower bathyal depths throughout the interval represented. Admixtures of species indicative of upper bathyal through upper middle bathyal depths commonly occur together with the in situ lower middle bathyal-lower bathyal biofacies providing additional evidence of continuous downslope transport of virtually all of the sediment present at Site 174. 
TABLE 10

Benthonic Foraminifera Identified at Site 174

Bolivina argentea Cushman

Bolivina pseudoplicata Heron-Allen and Earland

Buccella frigida (Cushman)

Buccella tenerrima (Bandy)

Bulimina striata mexicana Cushman

Buliminella elegantissima (d'Orbigy)

Buliminella exilis tenuata Cushman

Bulimina rostrata $\mathrm{H}$. B. Brady

Cassidulina delicata Cushman

Cassidulina depressa Asano \& Nakamura

Cassidulina limbata Cushman \& Hughes

Cassidulina minuta Cushman

Cibicides kullenbergi Parker

Cibicides spiralis Natland

Cibicides wullerstorfi (Schwager)

Cibicides bradyi (Trauth)

Discorbis globularis (d'Orbigny)

Eggerella bradyi (Cushman)

Elphidium clavatum (Cushman)

Elphidium incertum (Williamson)

Elphidium microgranulosum Galloway and Wissler

Epistominella exigua (Brady)

Epistominella pacifica (Cushman)

Fursenkoina complanta (Egger)

Globobulimina affinis (d'Orbigny)

Globobulimina spinifera (Cushman)

Gyroidina gemma Bandy

Gyroidina lamarckiana (d'Orbigny)

Gyroidina soldani (d'Orbigny)

Gyroidina subtener (Galloway and Wissler)

Hoeglundina elegans (d'Orbigny)

Martinotiella communis (d'Orbigny)

Melonis barleeanus (Williamson)

Melonis pompilioides (Fitchel and Moll)

Miliammina fusca (Brady)

Nonionella labradorica (Dawson)

Nonionella miocenica stella Cushman and Moyer

Oridorsalis umbonatus (Reuss)

Pullenia bulloides (d'Orbigny)

Pyrgo sp.

Quinqueloculina sp.

Sphaeroidina bulloides d'Orbigny

Textularia sp.

Trifarina angulosa (Williamson)

Uvigerina auberiana d'Orbigny

Uvigerina hispidocostata Cushman and Todd

Uvigerina juncea Cushman and Todd

Uvigerina peregrina Cushman

Uvigerina senticosa Cushman

Valvulineria araucana (d'Orbigny)

\section{SITE 175}

\section{Geologic and Stratigraphic Setting}

Site 175 is located within a small ponded basin formed within an area of anticlinal and synclinal ridges extant along the lower continental slope off central Oregon (Figure 1). Previous work in this offshore area (Byrne et al., 1966; Fowler and Kulm, 1970), together with evidence from exposures onshore of folded Miocene, Pliocene, and Pleistocene basinal deposits (Ogle, 1953) and recent unpublished seismic analyses, indicate that deformation of these sediments may have occurred within the last one million years. Thus, the primary objective at Site 175 was to date the folded sediments and the undeformed sediments above them in order to pin-point the last period of deformation and to assess these data within the context of possible underthrusting of the continental margin in this area (Silver, 1969, 1971a, b, c).

\section{Abundance and Preservation of Foraminifera}

A relatively uniform sequence of silty clays with infrequent fine sands was penetrated to a depth of 271 meters at Site 175 . Generally well preserved planktonic and benthonic foraminifera are common throughout these sediments down to Core $22(233 \mathrm{~m})$ and all are dated as Pleistocene in age (Tables 4, 11, and 12).

\section{Planktonic Foraminifera, Age, and Paleo-oceanography}

Quantitative analysis of planktonic foraminifera at Site 175 (Figure 5) reveals a series of faunas dominated by sinistral-coiling populations of Globigerina pachyderma with lesser percentages of $G$. bulloides (and variants), $G$. quinqueloba, Globigerinita glutinata, and G. uvula typical of the Pleistocene-Holocene interval in this area as detailed at Site 173. Variations in faunal composition indicate several significant oscillations in surface temperature occurred during the interval represented. Three intervals of increased surface temperature are marked by a change from exclusively sinistral to mixed dextral-sinistral coiling populations of Globigerina pachyderma along with simultaneous increases in the percentages of Globigerina bulloides and brief appearances of warm-temperate species, including Globorotalia crassaformis and G. inflata (Cores 8, $9,10,11$, and 19; Figure 5). A rare occurrence of Globigerinoides ruber occurs within the warmer biofacies present in Core 10 (Figure 5). Analogy with modern and known Pleistocene planktonic biofacies distributions within the California Current system (Bradshaw, 1959; Ingle, 1967; Kheradpir, 1970; Morin, 1971) suggest these particular faunal variations require an increase of minimum surface temperature to between $12^{\circ}$ and $15^{\circ} \mathrm{C}$ from a minimum of $5^{\circ}$ to $8^{\circ} \mathrm{C}$ during intervals dominated by sinistral populations of Globigerina pachyderma. It is also interesting to note that a significant interval of increased surface temperature of lesser scope is suggested by a major increase in the percentage of $G$. bulloides in Cores 15 and 16 (Figure 5) and the appearance of minor species including Globorotalia inflata. The absence of dextral populations of Globigerina pachyderma in this latter interval indicates a surface temperature just below that associated with the change from sinistral to mixed dextral coiling of this species or the migration of these individuals into the area concurrent with appearance of the limiting isotherms.

The absence of any distinctive Pliocene index species at Site 175 , together with the dominance of sinistral coiling populations of Globigerina pachyderma, indicate all of the sequence represented at Site 175 should be assigned to the Pleistocene and zone N. 22. A portion of the Holocene warming associated with zone N. 23 in this area may be present in Cores 1 and 2 (Figure 5).

\section{Benthonic Foraminifera and Paleobathymetry}

Water depth at Site 175 is 1999 meters, and upper through lower middle bathyal benthonic foraminifera typical of this depth are common in Cores 1 through 9 $(80 \mathrm{~m})$, including Uvigerina hispida and Pullenia bulloides. Species displaced from shallower upper bathyal through littoral environments are also present in varying abundances including Buccella frigida, Cassidulina californica, Uvigerina peregrina, and many others (Table 12). Melonis pompilioides, an index to lower bathyal environments today 
TABLE 11

Abundance and Stratigraphic Distribution of Planktonic Foraminifera, Site $175^{\mathrm{a}}$

\begin{tabular}{|c|c|c|c|c|c|c|c|c|c|c|c|c|c|c|c|c|c|c|}
\hline $\begin{array}{l}\text { Core, Section, } \\
\text { Interval }(\mathrm{cm})\end{array}$ & 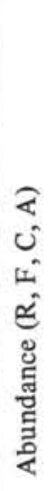 & 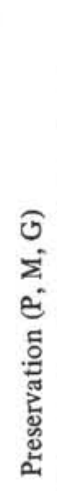 & 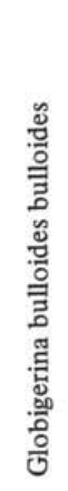 & 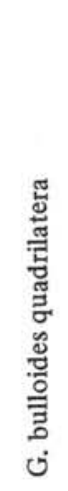 & 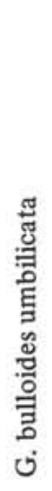 & 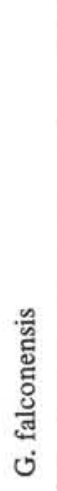 & 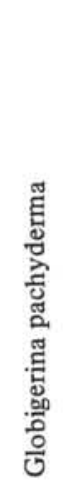 & 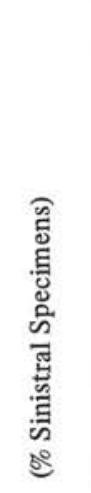 & 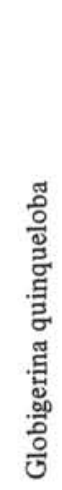 & 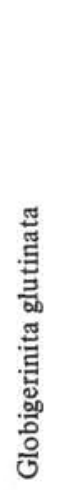 & $\begin{array}{l}\frac{\pi}{7} \\
\vdots \\
\dot{3}\end{array}$ & 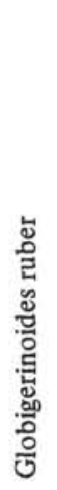 & 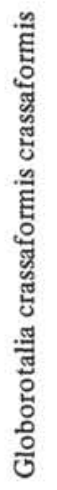 & 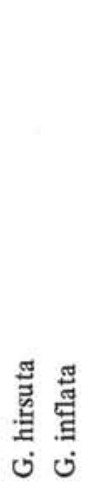 & (1) & 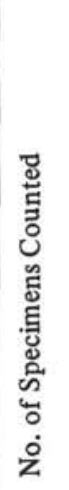 & స్ & $\stackrel{8}{<}$ \\
\hline $\begin{array}{l}1-1(101-103) \\
1-2(70-72) \\
1-3(70-72) \\
1-4(81-83) \\
1(C C) \\
2-1(100-102) \\
2-2(68-70) \\
2-3(68-70) \\
2-4(85-87) \\
2(C C)\end{array}$ & $\begin{array}{l}\text { C } \\
\text { A } \\
\text { C } \\
\text { C } \\
\text { C } \\
\text { C } \\
\text { C } \\
\text { A } \\
\text { A } \\
\text { C }\end{array}$ & $\begin{array}{l}\mathrm{G} \\
\mathrm{M} \\
\mathrm{M} \\
\mathrm{P} \\
\mathrm{P} \\
\mathrm{M} \\
\mathrm{M} \\
\mathrm{M} \\
\mathrm{P} \\
\mathrm{G}\end{array}$ & $\begin{array}{r}35 \\
7 \\
12 \\
15 \\
4 \\
15 \\
23 \\
12 \\
22 \\
9\end{array}$ & $\begin{array}{r}16 \\
6 \\
4 \\
2 \\
1 \\
3 \\
6 \\
1 \\
4 \\
\mathrm{X}\end{array}$ & $\begin{array}{l}3 \\
\mathrm{X} \\
\mathrm{X} \\
1 \\
\\
1 \\
\mathrm{X} \\
\mathrm{X} \\
1\end{array}$ & & $\begin{array}{l}35 \\
82 \\
71 \\
74 \\
87 \\
68 \\
59 \\
75 \\
65 \\
87\end{array}$ & $\begin{array}{r}(98) \\
(100) \\
(98) \\
(99) \\
(100) \\
(71) \\
(100) \\
(99) \\
(99) \\
(100)\end{array}$ & $\begin{array}{l}8 \\
3 \\
7 \\
4 \\
1 \\
9 \\
8 \\
8 \\
4 \\
2\end{array}$ & $\begin{array}{l}2 \\
\\
3 \\
3 \\
1 \\
X \\
4 \\
1 \\
2\end{array}$ & $\begin{array}{l}1 \\
\mathrm{X} \\
\mathrm{X} \\
\mathrm{X} \\
\mathrm{X} \\
\mathrm{X}\end{array}$ & & & $\begin{array}{l}X \\
X \\
1\end{array}$ & $\begin{array}{l}\mathrm{X} \\
\mathrm{X} \\
\mathrm{X} \\
\mathrm{X}\end{array}$ & $\begin{array}{l}156 \\
155 \\
159 \\
164 \\
116 \\
173 \\
189 \\
201 \\
204 \\
218 \\
\end{array}$ & \multirow{5}{*}{ Z̃ } & \\
\hline $\begin{array}{l}3-1(68-70) \\
3-2(67-69) \\
3-3(85-87) \\
3-4(83-85) \\
3-4(91-93) \\
3-5(68-70) \\
3(C C) \\
4-1(78-80) \\
4-2(60-62) \\
4-3(67-69)\end{array}$ & $\begin{array}{l}\text { C } \\
\text { C } \\
\text { C } \\
\text { F } \\
\text { C } \\
\text { A } \\
\text { A } \\
\text { C } \\
\text { C } \\
\text { C }\end{array}$ & $\begin{array}{l}G \\
G \\
M \\
M \\
M \\
G \\
G \\
G \\
M \\
M\end{array}$ & $\begin{array}{r}30 \\
5 \\
10 \\
3 \\
12 \\
9 \\
21 \\
14 \\
18 \\
8\end{array}$ & $\begin{array}{r}8 \\
3 \\
3 \\
\\
2 \\
3 \\
9 \\
7 \\
10 \\
2\end{array}$ & $\begin{array}{l}\mathrm{X} \\
9 \\
1 \\
\mathrm{X} \\
1\end{array}$ & & $\begin{array}{l}46 \\
88 \\
83 \\
87 \\
85 \\
83 \\
49 \\
68 \\
63 \\
84\end{array}$ & $\begin{array}{r}(96) \\
(99) \\
(100) \\
(89) \\
(97) \\
(99) \\
(99) \\
(99) \\
(100) \\
(99)\end{array}$ & $\begin{array}{r}12 \\
3 \\
X \\
4 \\
\\
2 \\
10 \\
7 \\
5 \\
2\end{array}$ & $\begin{array}{c}2 \\
1 \\
\mathrm{X} \\
\\
\mathrm{X} \\
2 \\
2 \\
\mathrm{X} \\
1\end{array}$ & $\begin{array}{r}\mathrm{X} \\
\mathrm{X} \\
2\end{array}$ & & & $\begin{array}{r}5 \\
\times \\
\times\end{array}$ & $\begin{array}{l}\mathrm{X} \\
\mathrm{X} \\
\mathrm{X}\end{array}$ & $\begin{array}{r}203 \\
171 \\
155 \\
76 \\
174 \\
213 \\
243 \\
205 \\
210 \\
172\end{array}$ & & 范 \\
\hline $\begin{array}{l}4-4(80-82) \\
4-5(60-62) \\
4(C C) \\
5-3(84-86) \\
5-5(27-29) \\
5-6(65-67) \\
5(C C) \\
6-1(79-81) \\
6-2(83-85) \\
6-4(78-80) \\
\end{array}$ & $\begin{array}{l}F \\
R \\
R \\
R \\
F \\
F \\
C \\
F \\
C \\
C \\
\end{array}$ & $\begin{array}{l}\mathrm{M} \\
\mathrm{P} \\
\mathrm{P} \\
\mathrm{P} \\
\mathrm{M} \\
\mathrm{M} \\
\mathrm{M} \\
\mathrm{M} \\
\mathrm{M} \\
\mathrm{M} \\
\end{array}$ & $\begin{array}{r}16 \\
X \\
\\
X \\
8 \\
27 \\
7 \\
16 \\
14 \\
18 \\
\end{array}$ & $\begin{array}{r}5 \\
10 \\
X \\
16 \\
5 \\
X \\
6 \\
2 \\
4 \\
\end{array}$ & $\begin{array}{l}\mathrm{X} \\
\mathrm{X}\end{array}$ & & $\begin{array}{r}77 \\
85 \\
X \\
57 \\
65 \\
89 \\
71 \\
79 \\
68\end{array}$ & $\begin{array}{r}(100) \\
(100) \\
(\mathrm{X}) \\
\\
(100) \\
(92) \\
(97) \\
(93) \\
(98) \\
(98) \\
\end{array}$ & $\begin{array}{l}2 \\
1 \\
4 \\
2 \\
4\end{array}$ & $\begin{array}{r}2 \\
3 \\
\mathrm{X} \\
2 \\
3\end{array}$ & 1 & & & $\begin{array}{l}\mathrm{X} \\
\mathrm{X} \\
\mathrm{X}\end{array}$ & $\begin{array}{l}\mathrm{X} \\
\mathrm{X} \\
\mathrm{X}\end{array}$ & $\begin{array}{r}129 \\
20 \\
10 \\
3 \\
44 \\
55 \\
114 \\
135 \\
152 \\
188\end{array}$ & & $\frac{\vec{w}}{\vec{a}}$ \\
\hline $\begin{array}{l}6-5(85-87) \\
6(C C) \\
7-2(60-62) \\
7-3(84-86) \\
7(C C) \\
8-2(83-85) \\
8(C C) \\
9-2(73-75) \\
9-3(75-77) \\
9-4(70-72)\end{array}$ & $\begin{array}{l}C \\
C \\
C \\
F \\
R \\
F \\
C \\
C \\
F \\
C\end{array}$ & $\begin{array}{l}\mathrm{M} \\
\mathrm{G} \\
\mathrm{G} \\
\mathrm{M} \\
\mathrm{M} \\
\mathrm{M} \\
\mathrm{G} \\
\mathrm{M} \\
\mathrm{M} \\
\mathrm{M}\end{array}$ & $\begin{array}{r}5 \\
13 \\
31 \\
30 \\
X \\
12 \\
26 \\
24 \\
23 \\
19\end{array}$ & $\begin{array}{r}1 \\
5 \\
7 \\
12 \\
X \\
5 \\
11 \\
14 \\
18 \\
8\end{array}$ & $\begin{array}{l}\mathrm{X} \\
\mathrm{X} \\
1 \\
2 \\
\mathrm{X} \\
\mathrm{X} \\
\mathrm{X} \\
1 \\
\mathrm{X} \\
\mathrm{X}\end{array}$ & & $\begin{array}{l}73 \\
73 \\
55 \\
51 \\
X \\
69 \\
39 \\
51 \\
56 \\
65\end{array}$ & $\begin{array}{r}(93) \\
(94) \\
(100) \\
(100) \\
(\mathrm{X}) \\
(56) \\
(80) \\
(100) \\
(98) \\
(97)\end{array}$ & $\begin{array}{r}6 \\
6 \\
5 \\
4 \\
\mathrm{X} \\
10 \\
16 \\
6 \\
8 \\
6\end{array}$ & $\begin{array}{r}4 \\
2 \\
2 \\
\mathrm{X}\end{array}$ & $\begin{array}{l}1 \\
\mathrm{X} \\
1 \\
2 \\
\mathrm{X}\end{array}$ & $\begin{array}{l}1 \\
\mathrm{X}\end{array}$ & $\mathrm{X}$ & $\begin{array}{l}1 \mathrm{X} \\
\mathrm{X}\end{array}$ & $\begin{array}{l}1 \\
X \\
X\end{array}$ & $\begin{array}{r}216 \\
183 \\
243 \\
192 \\
19 \\
77 \\
264 \\
232 \\
118 \\
162 \\
\end{array}$ & & \\
\hline $\begin{array}{l}9(\mathrm{CC}) \\
10-2(73-75) \\
10(\mathrm{CC}) \\
11-2(75-77)\end{array}$ & $\begin{array}{l}\mathrm{A} \\
\mathrm{F} \\
\mathrm{R} \\
\mathrm{R}\end{array}$ & $\begin{array}{l}\mathrm{G} \\
\mathrm{M} \\
\mathrm{P} \\
\mathrm{M}\end{array}$ & $\begin{array}{r}25 \\
44 \\
X \\
X\end{array}$ & $\begin{array}{l}11 \\
16 \\
X\end{array}$ & $\begin{array}{l}1 \\
3\end{array}$ & & $\begin{array}{r}62 \\
29 \\
\mathrm{X} \\
\mathrm{X}\end{array}$ & $\begin{array}{l}(99) \\
(92) \\
(\mathrm{X}) \\
(\mathrm{X})\end{array}$ & $\begin{array}{l}X \\
3\end{array}$ & $\begin{array}{r}2 \\
5 \\
X\end{array}$ & & & & $\mathrm{X}$ & & $\begin{array}{r}187 \\
52 \\
2 \\
14\end{array}$ & & \\
\hline
\end{tabular}

(Bandy and Chierci, 1966), makes its first appearance in Core 4 at Site 175 consistant with the in situ lower middle bathyal biofacies present in these sediments. Significantly, this species increases in frequency between Cores 4 through $10(24$ to $80 \mathrm{~m})$ and becomes a common member of faunas below this interval (Figure 5). Studies of the present distribution of this species along the eastern margin of the North Pacific (Bandy, 1961; Ingle, 1967) and elsewhere
(Bandy and Chierci, 1966; Asano et al., 1969) clearly indicate that the common occurrence of this species is restricted to depths in excess of 2200 to 2500 meters. Thus, the common appearance of this species within the 80 to 271 meter interval at Site 175 strongly suggests that these sediments were deposited at depths in excess of 2200 meters and later uplifted to their present depth of 1999 meters sometime during the mid- or late Pleistocene. 
TABLE 11 - Continued

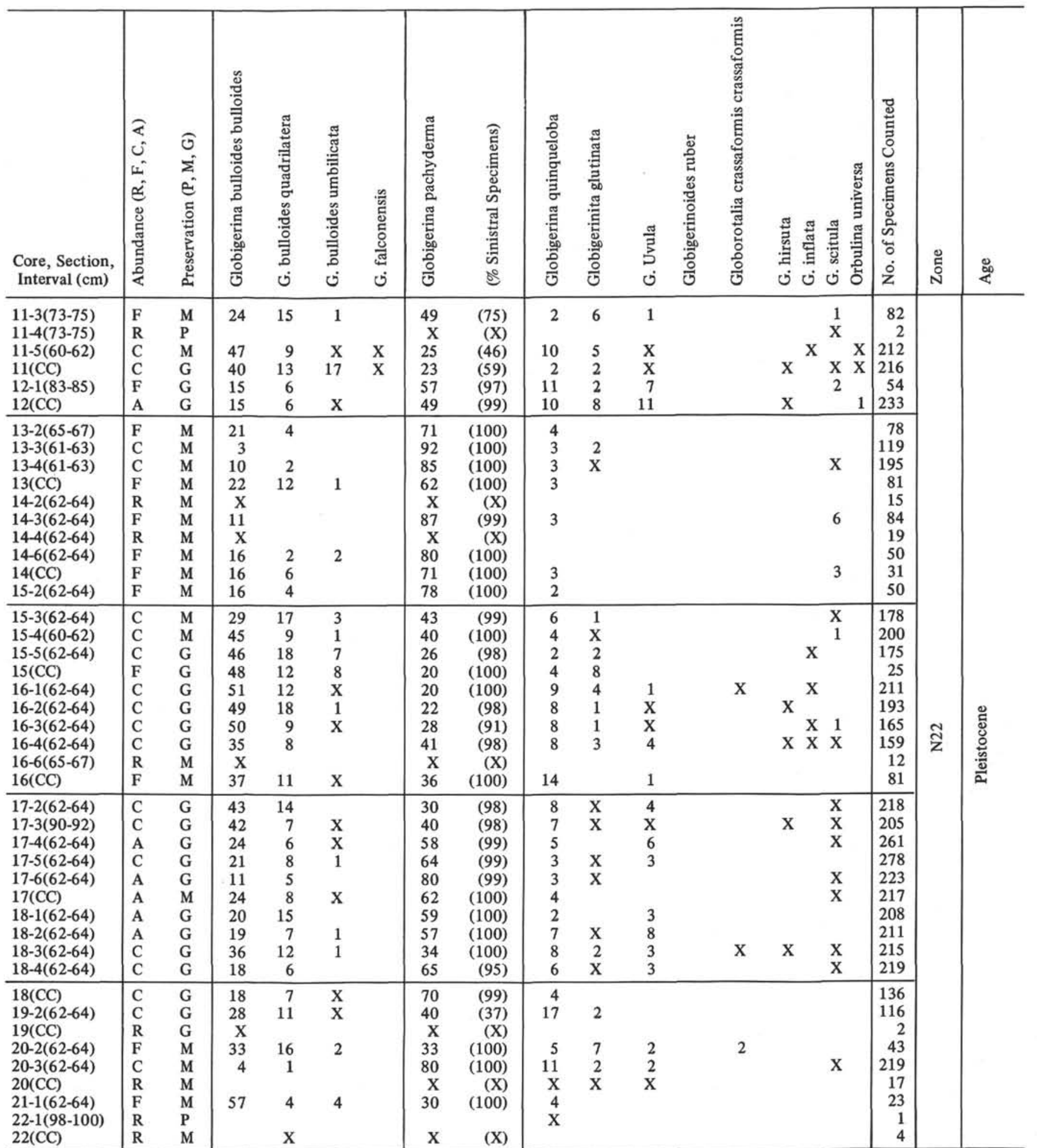

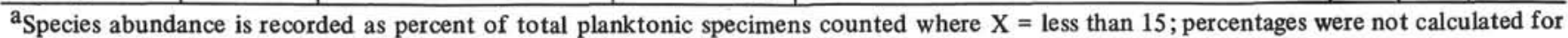
samples containing less than 20 specimens and $\mathrm{X}$ simply denotes species presence in these samples. 
TABLE 12

Benthonic Foraminifera Identified at Site $\mathbf{1 7 5}$

Bolivina argentea Cushman

Bolivina tumida Cushman (reworked Miocene species) Buccella frigida (Cushman)

Bulimina aculeata d'Orbigny

Bulimina rostrata $\mathrm{H}$. B. Brady

Bulimina striata d'Orbigny var. mexicana Cushman

Buliminella exilis (H. B. Brady) var. tenuata Cushman

Cassidulina californica Cushman and Hughes

Cassidulina delicata Cushman

Cassidulina islandica Norvang

Cassidulina laevigata d'Orbigny

Cassidulina limbata Cushman and Hughes

Cassidulina minuta Cushman

Cassidulina norcrossi Cushman

Cassidulina subglobosa Brady

Cassidulina translucens Cushman and Hughes

Cassidulinoides cornuta (Cushman)

Cassidulinoides cf. mexicana (Cushman)

Chilostomella fimbricata Cushman

Chilostomella oolina Schwager

Cibicides kullenbergi Parker

Cibicides mckannai Galloway and Wissler

Cibicides spiralis Natland

Cibicides wullerstorfi (Schwager)

Cribrononion sp.

Eggerella bradyi (Cushman)

Eilohedra levicula (Resig)

Elphidium incertum (Williamson)

Epistominella exigua (Brady)

Fissurina lucida (Williamson)

Fursenkoina complanata (Egger)

Globobulimina affinis (d'Orbigny)

Globobulimina barbata (Cushman)

Globobulimina ovula (d'Orbigny)

Globobulimina spinifera (Cushman)

Globobulimina subaffinis (Cushman)

Gyroidina gemma Bandy

Gyroidina lamarckiana (d'Orbigny)

Gyroidina soldani d'Orbigny

Gyroidina subtener (Galloway and Wissler)

Hoeglundina elegans (d'Orbigny)

Melonis barleeanus (Williamson)

Melonis pompilioides (Fichtel and Moll)

Nonionella auricula Heron, Allen, and Earland

Nonionella miocenica stella Cushman and Moyer

Oridorsalis umbonatus (Reuss)

Pullenia bulloides (d'Orbigny)

Pullenia salisburyi Stewart and Stewart

Pyrgo sp.

Pyrgo murrhina (Schwager)

Quinqueloculina sp.

Sphaeroidina bulloides d'Orbigny

Uvigerina auberiana d'Orbigny

Uvigerina hispida Cushman

Uvigerina hispidocostata Cushman and Todd

Uvigerina peregrina Cushman

Uvigerina senticosa Cushman

Valvulineria araucana (d'Orbigny)

Valvulineria laevigata (Phleger and Parker)

\section{SITE 176}

\section{Geologic and Stratigraphic Setting}

Site 176 is located in 193 meters of water at the outer edge of the continental shelf southwest of the Columbia River and the Oregon mainland (Figure 1). Samples from Nehalem Banks due east of this location indicate that the shelf in this area represents an erosional surface developed on folded Pliocene (?) and older sediments covered with a generally thin layer of Pleistocene sediment, typical of many shelf areas today (Emery, 1965). The primary scientific objective at this site was to evaluate the age of the angular unconformity separating the undeformed blanket of Holocene-Pleistocene shelf sediments from the underlying folded strata. The regional nature of this most recent unconformity has been established by recent seismic surveys over adjacent portions of the shelf (Kulm et al., Appendix 1) and studies in the Nehalem Bank area (Kulm and Fowler, 1971).

Drilling at Site 176 penetrated a characteristically thin $(41 \mathrm{~m})$ sequence of greenish gray muds and glauconitic sands representing the undeformed Holocene-Pleistocene sediment blanket. A hard fissile gray shale was encountered at the base of Core $5(41 \mathrm{~m})$ representing the upper portion of the underlying folded unit of probable Pliocene (?) age. Pholad-bored rocks, broken mollusk shells, and abundant glauconite provide lithologic evidence that the 41-meter thick unit of shelf sediments is largely relict in nature and represents deposits from several transgressions and regressions of the Pleistocene strand line across this portion of the shelf.

As an aside, it should be noted that the stratigraphy of the relatively thin deposit of shelf sediments at Site 176 is probably homogenized to an unknown degree by the prolific benthic megainvertebrate infauna common to the shelf environment, ultimately limiting the resolution of short-term events as recorded in this sequence.

\section{Abundance and Preservation of Foraminifera}

Generally well preserved Pleistocene planktonic and benthonic foraminifera are common to abundant within the 41 meters of muds and sands representing shelf deposition. In contrast, only a few specimens of foraminifera per unit of rock characterize the underlying hard shale unit.

\section{Planktonic Foraminifera, Age, and Paleo-oceanography}

Planktonic foraminiferal faunas within the 41 meters of unconsolidated shelf sediments (Cores 1 to $5 ; 0-41 \mathrm{~m}$ ) are dominated by sinistral-coiling populations of Globigerina pachyderma along with varying percentages of $G$. bulloides and G. quinqueloba (Figure 6). Globigerina quinqueloba occurs in greater abundances than is common in offshore deposits, and the faunas lack the normal compliment of minor species usually present even at this relatively high latitude, likely due to the rigor of shelf conditions. These faunas are interpreted as Pleistocene in age and are correlated with zone N. 22 with exception of the youngest sediments present, which may include the HolocenePleistocene transition (Figure 6).

Exclusively sinistral-coiling populations of Globigerina pachyderma are again interpreted as representing subarctic surface temperatures. However, two intervals of slightly higher temperature are indicated by the appearance of mixed dextral-sinistral coiling populations of G. pachyderma in Cores 1, 2, and 3 (Figure 6). A third sharp rise in temperature is marked by dominantly dextral populations of this species in Core 5 near the base of the shelf sediments. Globorotalia inflata occurs as a rare element within the warmer interval defined within Core 3 (Figure 6). However, absence of temperature-sensative 


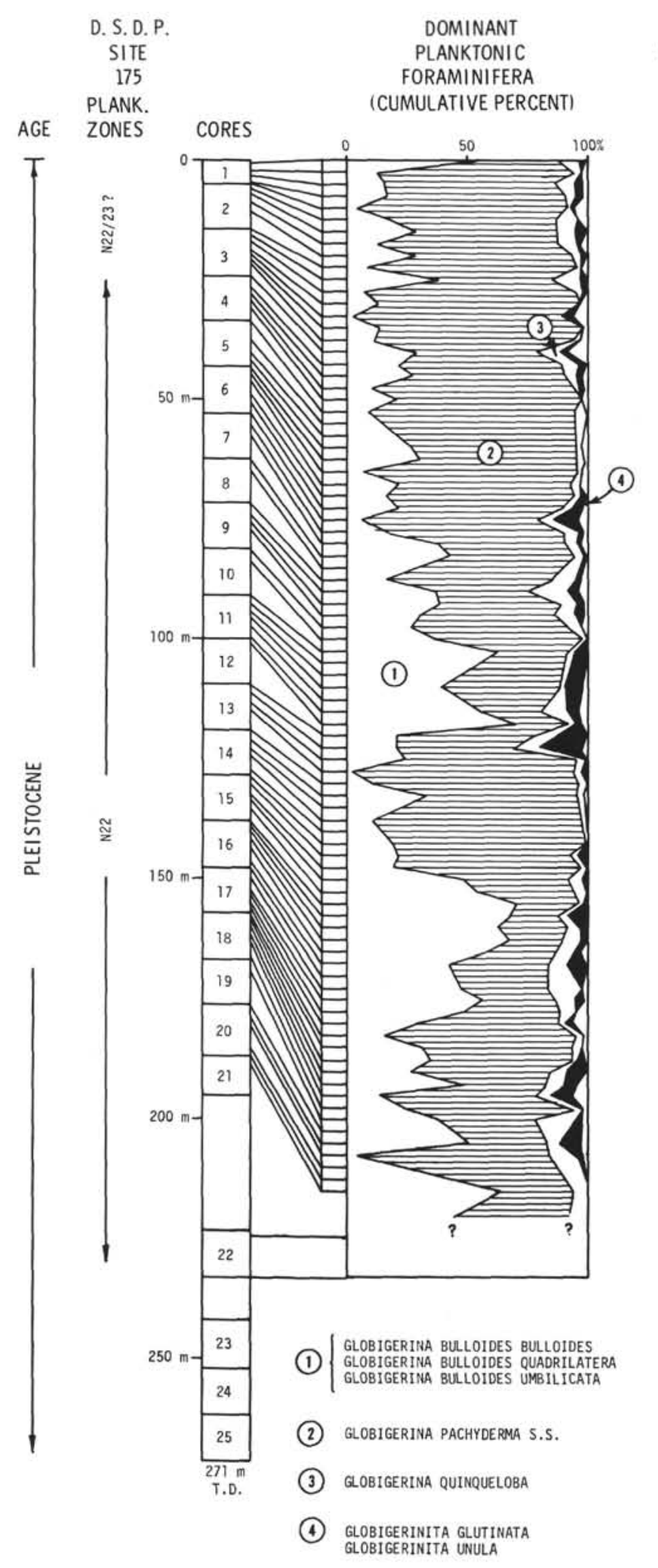

COILING

GLOBIGERINIA

PACHYDERMA

$100 \% 50 \quad 100 \% 0$

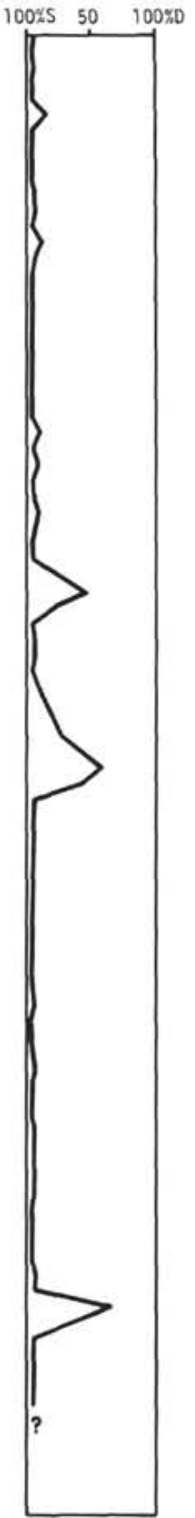

a

a
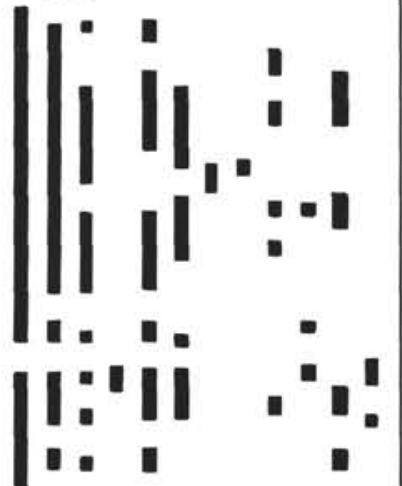

1.
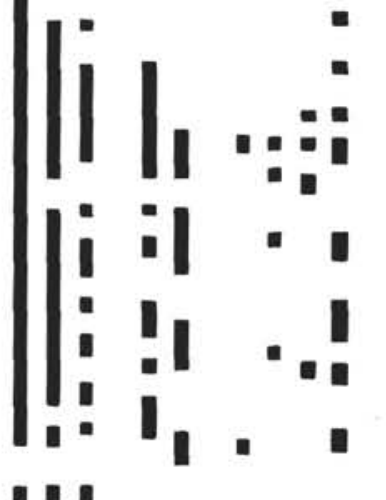

ESTIMATED

MINIMUM

SURFACE

TEMPERATURE

$\left({ }^{\circ} \mathrm{C}\right)$
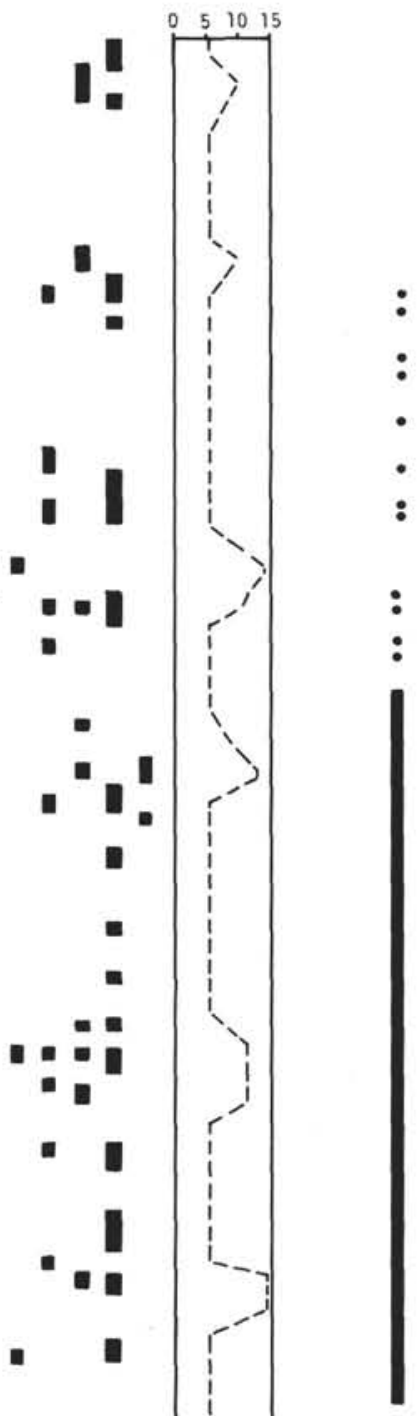

$* D=$ DEXTRAL

Figure 5. Stratigraphic variation of dominant planktonic species, ranges of selected planktonic species, variation of estimated minimum surface temperatures, and stratigraphic range of Melonis pompilioides, Site 175. 


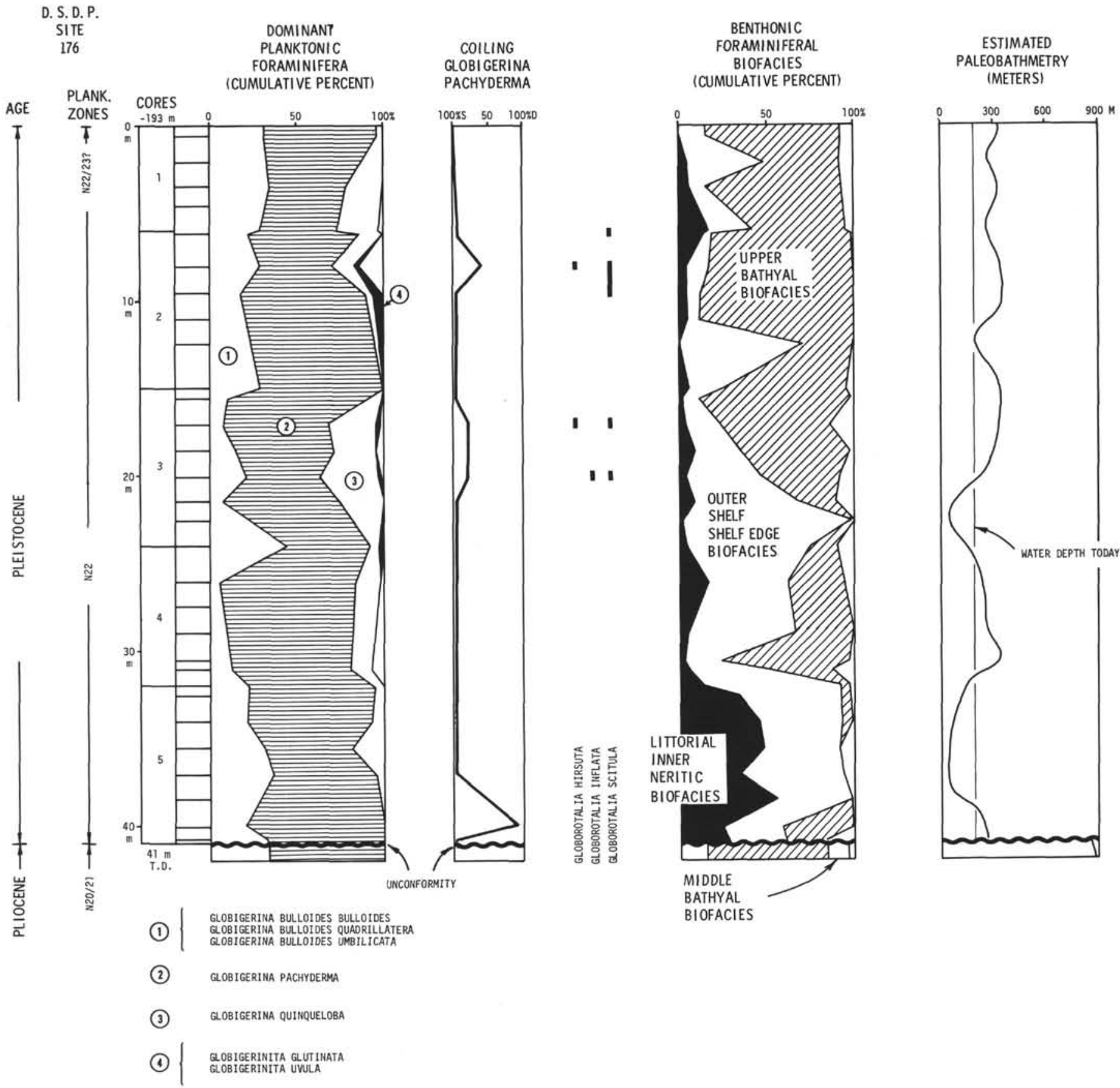

Figure 6. Stratigraphic variation of dominant planktonic species and benthonic biofacies, ranges of selected planktonic species, and variation of estimated paleobathymetry, Site 176.

minor species at Site 176 is likely due to exclusion from the shelf environment rather than migration of isotherms. Minor unconformities are almost surely present within this sequence of shelf deposits due to erosion during low stands of sea level coincident with glacial maxima. Thus, the faunal variations recorded at this site in all probability do not represent a complete picture of paleotemperature events for that interval of the Pleistocene represented.

The somewhat meager planktonic foraminiferal fauna present in the hard fissile shale underlying the shelf deposits at Site 176 is composed of large robust specimens of dextral-coiling specimens of Globigerina pachyderma along with $G$. bulloides. The size and exclusively dextral-coiling habit of $G$. pachyderma within this unit indicate minimum surface temperature in excess of $15^{\circ} \mathrm{C}$, in turn suggesting correlation with warmer intervals associated with the Pliocene-Pleistocene boundary in this area (Figure 3, Site 173). The absence of Globorotalia puncticulata or any other species indicative of the mid- or early Pliocene age for these deformed sediments. Thus, the interval represented by the major angular unconformity at the base of the undeformed shelf deposits may be relatively short if the base of these shelf deposits is assumed to be midPleistocene or younger. 
TABLE 13

Abundance and Stratigraphic Distribution of Planktonic Foraminifera, Site $176^{\mathrm{a}}$

\begin{tabular}{|c|c|c|c|c|c|c|c|c|c|c|c|c|c|c|c|c|c|c|}
\hline $\begin{array}{c}\text { Core, Section, } \\
\text { Interval }(\mathrm{cm})\end{array}$ & 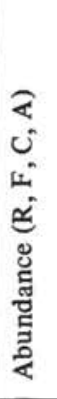 & 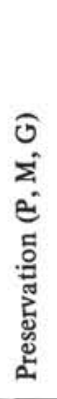 & 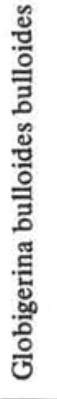 & 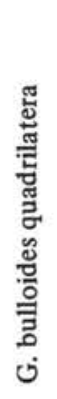 & 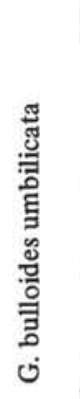 & 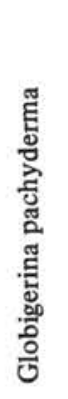 & 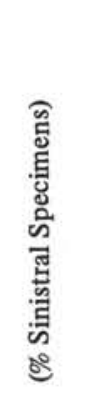 & 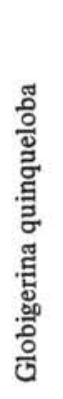 & 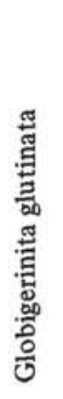 & $\begin{array}{l}\frac{\pi}{3} \\
0\end{array}$ & 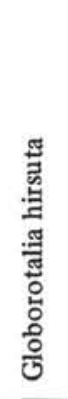 & 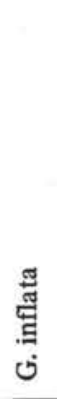 & 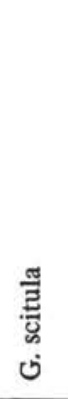 & 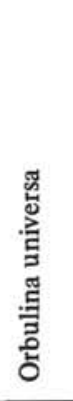 & 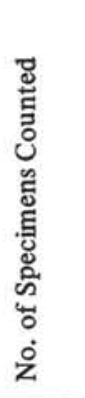 & 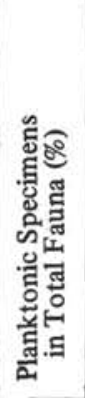 & ్ㅠ & 品 \\
\hline $\begin{array}{l}1-1(60-62) \\
1-1(62-64) \\
1-3(56-58) \\
1-4(15-17) \\
1(C C) \\
2-1(17-19) \\
2-2(59-61) \\
2-3(62-64) \\
2-4(62-64) \\
2-5(62-64) \\
\end{array}$ & $\begin{array}{l}\mathrm{C} \\
\mathrm{R} \\
\mathrm{C} \\
\mathrm{R} \\
\mathrm{C} \\
\mathrm{C} \\
\mathrm{F} \\
\mathrm{F} \\
\mathrm{R} \\
\mathrm{R}\end{array}$ & $\begin{array}{l}\mathrm{G} \\
\mathrm{G} \\
\mathrm{G} \\
\mathrm{M} \\
\mathrm{G} \\
\mathrm{M} \\
\mathrm{G} \\
\mathrm{G} \\
\mathrm{M} \\
\mathrm{M} \\
\end{array}$ & $\begin{array}{r}21 \\
22 \\
X \\
23 \\
21 \\
29 \\
16 \\
X \\
X \\
\end{array}$ & $\begin{array}{l}5 \\
1\end{array}$ & $\begin{array}{l}3 \\
1\end{array}$ & $\begin{array}{r}66 \\
X \\
44 \\
X \\
44 \\
64 \\
51 \\
71 \\
X \\
X \\
\end{array}$ & $\begin{array}{r}(100) \\
(\mathrm{X}) \\
(99) \\
(\mathrm{X}) \\
(95) \\
(96) \\
(57) \\
(96) \\
(\mathrm{X}) \\
(\mathrm{X}) \\
\end{array}$ & $\begin{array}{r}3 \\
\\
23 \\
X \\
24 \\
13 \\
13 \\
4 \\
X\end{array}$ & $\begin{array}{l}2 \\
5\end{array}$ & 1 & 2 & & $\begin{array}{l}2 \\
1\end{array}$ & & $\begin{array}{r}29 \\
2 \\
120 \\
8 \\
88 \\
82 \\
45 \\
56 \\
10 \\
5 \\
\end{array}$ & $\begin{array}{r}14 \\
2 \\
56 \\
35 \\
48 \\
52 \\
27 \\
37 \\
9 \\
3 \\
\end{array}$ & \multirow[b]{2}{*}{ స̃ } & \multirow{2}{*}{ 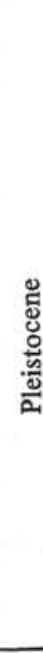 } \\
\hline $\begin{array}{l}2(C C) \\
3-1(62-64) \\
3-2(62-64) \\
3-3(62-64) \\
3-4(62-64) \\
3-5(62-64) \\
3(C C) \\
4-2(65-67) \\
4-3(52-54) \\
4-4(52-54) \\
\end{array}$ & $\begin{array}{l}\text { C } \\
\text { F } \\
\text { C } \\
\text { C } \\
\text { C } \\
\text { F } \\
\text { F } \\
\text { C } \\
\text { R } \\
\text { R }\end{array}$ & $\begin{array}{l}\mathrm{G} \\
\mathrm{G} \\
\mathrm{G} \\
\mathrm{G} \\
\mathrm{G} \\
\mathrm{G} \\
\mathrm{M} \\
\mathrm{G} \\
\mathrm{P} \\
\mathrm{P}\end{array}$ & $\begin{array}{r}25 \\
10 \\
8 \\
12 \\
18 \\
7 \\
32 \\
5\end{array}$ & $\begin{array}{l}3 \\
3\end{array}$ & 2 & $\begin{array}{l}69 \\
90 \\
60 \\
56 \\
42 \\
67 \\
47 \\
78 \\
X \\
X \\
\end{array}$ & $\begin{array}{r}(100) \\
(100) \\
(82) \\
(83) \\
(84) \\
(98) \\
(100) \\
(99) \\
(\mathrm{X}) \\
(\mathrm{X}) \\
\end{array}$ & $\begin{array}{r}X \\
27 \\
24 \\
33 \\
26 \\
6 \\
15\end{array}$ & 3 & $\begin{array}{l}2 \\
5 \\
1\end{array}$ & 2 & 2 & $\mathrm{X}$ & $\mathrm{X}$ & $\begin{array}{r}52 \\
32 \\
129 \\
75 \\
91 \\
27 \\
34 \\
41 \\
1 \\
4 \\
\end{array}$ & $\begin{array}{l}29 \\
33 \\
54 \\
41 \\
46 \\
13 \\
18 \\
18 \\
13 \\
26 \\
\end{array}$ & & \\
\hline $\begin{array}{l}4-5(65-67) \\
4-6(62-64) \\
4(C C) \\
5-1(68-70) \\
5-2(62-64) \\
5-3(60-62) \\
5-4(60-62) \\
5-5(65-67) \\
5-6(63-65) \\
5-6(135-137) \\
\end{array}$ & $\begin{array}{l}\mathrm{R} \\
\mathrm{F} \\
\mathrm{C} \\
\mathrm{R} \\
\mathrm{F} \\
\mathrm{F} \\
\mathrm{F} \\
\mathrm{R} \\
\mathrm{F} \\
\mathrm{C} \\
\end{array}$ & $\begin{array}{l}\mathrm{P} \\
\mathrm{M} \\
\mathrm{G} \\
\mathrm{G} \\
\mathrm{G} \\
\mathrm{G} \\
\mathrm{G} \\
\mathrm{M} \\
\mathrm{G} \\
\mathrm{M}\end{array}$ & $\begin{array}{r}\mathrm{X} \\
12 \\
18 \\
\mathrm{X} \\
17 \\
21 \\
33 \\
\mathrm{X} \\
10 \\
25 \\
\end{array}$ & $\begin{array}{r}2 \\
X \\
4 \\
29 \\
3 \\
\\
10 \\
7 \\
\end{array}$ & 2 & $\begin{array}{r}\mathrm{X} \\
80 \\
73 \\
\mathrm{X} \\
71 \\
50 \\
59 \\
\mathrm{X} \\
89 \\
68 \\
\end{array}$ & $\begin{array}{r}(\mathrm{X}) \\
(100) \\
(97) \\
(\mathrm{X}) \\
(100) \\
(100) \\
(100) \\
(\mathrm{X}) \\
(9) \\
(96) \\
\end{array}$ & $\begin{array}{c}\mathrm{X} \\
8 \\
5 \\
8 \\
8 \\
5\end{array}$ & & & & & & & $\begin{array}{r}19 \\
41 \\
44 \\
16 \\
48 \\
24 \\
39 \\
9 \\
89 \\
40 \\
\end{array}$ & $\begin{array}{r}17 \\
33 \\
22 \\
8 \\
22 \\
9 \\
18 \\
11 \\
36 \\
25 \\
\end{array}$ & $\frac{\mathrm{N}}{\mathrm{a}}$ & 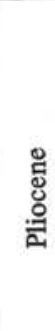 \\
\hline $5(\mathrm{CC})$ & $\mathrm{F}$ & $\mathrm{M}$ & 33 & & & 67 & $(0)$ & & & & & & & & 21 & 53 & $\bar{z}$ & \\
\hline
\end{tabular}

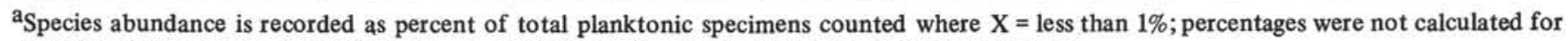
samples containing less than 20 specimens and X simply denotes species presence in these samples.

Benthonic Foraminifera and Paleobathymetry

Common species of benthonic foraminifera were arranged into four depth-dependent biofacies at Site 176 (Tables 14 and 15) indicative of littoral, outer shelf-shelf edge, upper bathyal, and upper middle bathyal depths. A cumulative percentage diagram depicting variations in the abundance of these four biofacies in time at Site 176 (Figure 6) has a number of implications regarding variation in depth of water at this site. Indeed, the stratigraphic variation of these four biofacies is interpreted directly as a function of varying depth of water, and a curve depicting estimated paleobathymetry at this site is presented in terms of deviation from the present water depth at Site 176 (Figure 6). Upper bathyal faunas generally prevail in the 0 to 20 meter interval indicating depths in excess of the present depth $(193 \mathrm{~m})$, whereas outer shelf-shelf edge and littoral biofacies dominate at two horizons in the 20 to 41 meter interval indicating depths shallower than today (Figure 6).

Oscillations in depth of water at this site in all likelihood represent the combined effects of eustatic changes in sea level during glacial maxima and minima and tectonic flexing of the shelf edge. The present depth of the shelf unconformity is about 100 meters deeper than the presumed lowest Pleistocene sea level (Curray, 1965) implying that subsidence of the shelf has occurred since erosion of this surface. Initiation of subsidence may be coincident with the major decrease in the frequency of shelf biofacies at 20 meters (Core 3) just prior to the sustained appearance of upper bathyal biofacies (Figure 6).

A more conservative interpretation of these biofacies changes would allow water depth to hover near the present 
TABLE 14

Benthonic Foraminiferal

Biofacies, Site 176

Inner Shelf-Littoral Biofacies (0-50 m)

Astrononion gallowayi

Buccella frigida

Buccella tenerrima

Buliminella elegantissma

Cibicides fletcheri

Cibicides lobatus

Elphidium bartletti

Elphidium clavatum

Elphidium incertum

Gaudryina arenaria

Nonionella miocenica stella

Quinqueloculina akneriana

Rotorbinella lomaensis

Outer Shelf-shelf-edge Biofacies $(\mathbf{5 0 - 2 0 0} \mathbf{m})^{\mathbf{b}}$
Cassidulina californica
Cassidulina islandica
Cassidulina limbata
Cassidulina minuta
Cassidulina norcrossi
Cassidulina subglobosa quadrata
Epistominella subperuviana
Globobulimina ariculata
Nonionella labradorica
Pullenia salisburyi
Trifarina angulosa
Uvigerina juncea

Upper Bathyal Biofacies $(200-500 \mathrm{~m})^{\mathrm{b}}$

Bolivina pseudoplicata

Bulimina aculeata

Cassidulina delicata ${ }^{\mathrm{a}}$

Cassidulina translucens

Epistominella exigua ${ }^{\mathrm{a}}$

Epistominella pacifica ${ }^{\mathrm{a}}$

Globobulimina affinis

Uvigerina peregrina

Upper Middle Bathyal Biofacies $(500-1500 \mathrm{~m})^{\mathrm{c}}$

Eilohedra levicula

Cassidulinoides cornuta

a species also occurring in abundance at middle bathyal depths; emphasis here is placed on their initial appearance at upper bathyal depths.

$b$ note that definition of an outer shelf-shelf edge biofacies required modification of the depth limits assigned to the upper bathyal zone as used in this report (Table 2).

${ }^{c}$ Epistominella pacifica and other species first appearing in the upper bathyal biofacies are also abundant in this zone.

Depth ranges obtained from references cited in Ingle (1967, p. 245) and Asano, Ingle, and Takayanagi (1969) along with data in Loeblich and Tappan (1953), Manske (1968), and Feyling-Hanssen (1964).

depth at this site during intervals where upper bathyal biofacies predominate. Thus, a crude standard deviation of plus or minus 50 meters should be applied to the bathymetric curve presented on Figure 6.

Unfortunately, comparison of the estimated curve of paleodepth with the diagram depicting variation in planktonic biofacies suggests only a subtle correlation between depth of water and surface temperature. Nevertheless, upper bathyal biofacies, possibly indicating the transgressive phase of a eustatic cycle, are present within each interval where warmer surface temperatures are indicated.
An upper bathyal-upper middle bathyal benthonic biofacies dominated by Epistominella pacifica, Uvigerina peregrina, and Cassidulinoides cornuta occurs with the hard fissile shale underlying the 41-meter thick blanket of Pleistocene shelf deposits. This fauna is interpreted as representing a minimum water depth of 800 to 900 meters, in turn demonstrating that these sediments have experienced significant uplift of at least 600 meters or more, probably in concert with folding. Finally, truncation of these beds occurred prior to deposition of Pleistocene shelf sediments.

The Epistominella pacifica-rich foraminiferal biofacies present within the gray fissile shale at Site 176 can be correlated with a similar biofacies present in portions of bathyal marine sections referred to the Quinault Formation of coastal Washington (Fowler, 1965; Rau, 1970), the Wildcat Series exposed in northern California (Cushman et al., 1930; Ogle, 1953), and the Fernando Formation of southern California (Ingle, 1972), all traditionally placed within the later Pliocene on the basis of provincial benthonic foraminiferal and molluscan stages (Natland, 1958; Faustman, 1963). Thus, the presence of this particular benthonic biofacies also favors a late Pliocene or early Pleistocene age for this unit.

\section{SITE 177}

\section{Geologic and Stratigraphic Setting}

A sequence of alternating sandy muds, silts, and sandstones representing a series of early Pliocene through Pleistocene submarine fan deposits was penetrated at Site 177. This site is located at the northwestern terminus of Paul Revere Ridge west of Vancouver Island, Canada (Figure 1), at or near the triple junction of the Pacific, American, and Juan de Fuca plates. The location of this site thus portends a complex structural history for these deposits (Atwater, 1970). Recent work (Murray and Tiffin, 1969; Tiffin et al., 1972) has demonstrated that the sedimentary deposits forming Paul Revere Ridge represent the uplifted and deformed distal portion of a thick sedimentary wedge representing earlier (Plio-Pleistocene) deposition along the continental margin within the Winona Basin. Deformation of these sediments is thought to be related to episodes of complex plate motion initiated at the adjacent triple junction.

The primary objective at Site 177 was to date the basal units of the deformed sedimentary sequence forming Paul Revere Ridge in order to assess the age of the underlying acoustic basement, in turn providing insight into the timing of the most recent episode of motion associated with the adjacent triple junction.

\section{Abundance and Preservation of Foraminifera}

A major portion of the sediments recovered at Site 177 are barren of both planktonic and benthonic foraminifera or contain only marginal faunas in terms of abundance and preservation (Table 3). Well-preserved planktonic faunas are common in the single core recovered at site 177 ( 0 to $9 \mathrm{~m}$ ), whereas moderately to well-preserved planktonic faunas are present from 9 to 31 meters (Cores 1 to 3 ) and 42 to 46.6 meters (Cores 4 and 5) in Hole 177A. Extensive intervals in Hole 177A from 61 to 174.5 meters (Cores 7 to 13) and 212 to 378.5 meters (Cores 15 to 24 ) are essentially barren 
TABLE 15

Abundance and Stratigraphic Distribution of Benthonic Foraminifera, Site $176^{\mathrm{a}}$

\begin{tabular}{|c|c|c|c|c|c|c|c|c|c|c|c|c|c|c|c|c|c|c|c|c|c|c|c|c|c|c|c|c|c|c|}
\hline $\begin{array}{l}\text { Core, Section, } \\
\text { Interval }(\mathrm{cm})\end{array}$ & 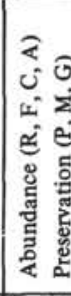 & 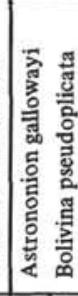 & 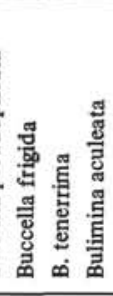 & 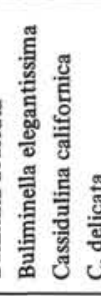 & 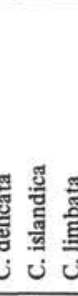 & 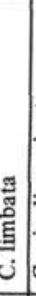 & & & 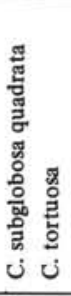 & 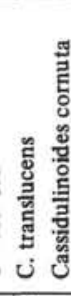 & 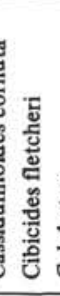 & 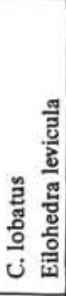 & 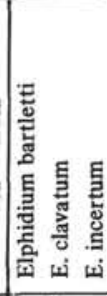 & 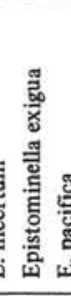 & 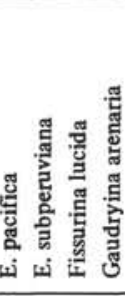 & 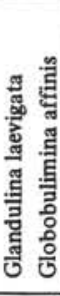 & 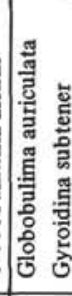 & 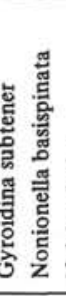 & 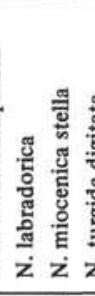 & 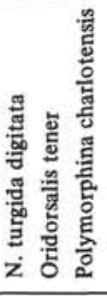 & 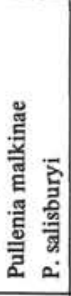 & 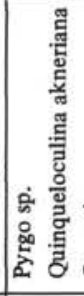 & 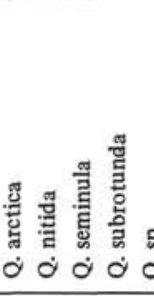 & 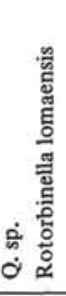 & 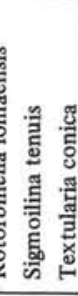 & & 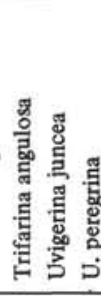 & 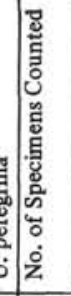 & ลूँ & $\underset{8}{<}$ \\
\hline $1-1(60-62)$ & $A G$ & $\mathrm{x}$ & & & $\times 5$ & 5 & 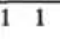 & & $\mathrm{x}$ & 9 & & & $\mathrm{x}$ & 253 & & 1 & & & $\mathrm{x}$ & & & & & & & $x$ & $\mathrm{x}$ & 3171 & & \\
\hline $1-2(62-64)$ & C G & $\mathrm{x}$ & $\mathrm{x} \times \mathrm{x}$ & 43 & & & & & & 19 & & $\mathrm{x}$ & $\mathrm{x}$ & & 3 & $\mathrm{x}$ & & & 4 & & & & & & & & $\begin{array}{ll}\mathrm{X} & 21\end{array}$ & 97 & & \\
\hline $1-3(56-58)$ & C $\quad \mathrm{G}$ & 2 & 1 & & 5 & 5 & & & & 10 & & $\mathrm{x}$ & & $\times 60$ & & 6 & & & 2 & & & & & 2 & 1 & & 2 & 196 & & \\
\hline $1-4(15-17)$ & & & & & & & & & & $\mathrm{x}$ & & & & & $x$ & $\mathrm{x}$ & & & $\mathrm{x}$ & & & & & & & & & 95 & & \\
\hline $1(\mathrm{CC})$ & A G & 4 & $\mathrm{x}$ & $\mathrm{x}$ & 9 & 9 & & & & 5 & & $\mathrm{x}$ & 41 & 1224 & & 5 & & & $1212 x$ & & 1 & $\mathrm{x}$ & $\mathrm{x} \times$ & & 1 & & 33 & 315 & & \\
\hline $2-1(17-19)$ & C M & 4 & & & $\mathrm{x}$ & $x$ & & & $\mathrm{x}$ & 15 & & 1 & 33 & & 52 & 5 & & & 44 & & & 3 & & & & & $\begin{array}{ll}X & 4\end{array}$ & 475 & & \\
\hline $2-2(59-61)$ & C G & 4 & & & 10 & 0 & & & & 15 & & $\mathrm{x}$ & $\mathrm{x}$ & 248 & & 6 & & & 3 & & $\mathrm{x}$ & & & & & & $2 \times 8$ & 8124 & & \\
\hline 2-3(62-64) & F G & 3 & & & & 6 & & & & 3 & & & 1 & & 3 & 3 & & & 13 & & & & & & & & & 695 & & \\
\hline $2-4(62-64)$ & F M & 4 & 1 & & & 3 & & & & 10 & & 1 & 2 & 166 & & 2 & & & & & & & & & & & 2 & 798 & & \\
\hline $2-5(62-64)$ & C M & & & 71 & $\mathrm{X}$ & $x$ & & & $\mathrm{x}$ & 10 & & & & & 7 & 1 & & & $\mathrm{x}$ & & & & & & 3 & & 12 & 2163 & & \\
\hline $2(\mathrm{CC})$ & C G & & $\mathrm{x}$ & 31 & & & & & & 45 & & & $\mathrm{x}$ & 415 & & 1 & & & 172 & & & & & & & & 2 & 5126 & & \\
\hline 3-1(62-64) & F P & & & 1 & & & & & & 25 & & 1 & & X 55 & & 5 & & & 1 & & & & & & & & $\begin{array}{lll}5 & 1 & 1\end{array}$ & $1 \quad 64$ & & 8 \\
\hline $3-2(62-64)$ & F G & & & 5 & $x \quad 7$ & 72 & 2 & & & 38 & & 2 & & 21 & 1 & & & & $\begin{array}{ll}4 & 1\end{array}$ & & & & & $\mathrm{x}$ & & $x$ & $1 \times 21$ & 1111 & $\tilde{z}$ & 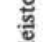 \\
\hline $3-3(62-64)$ & C G & & & 5 & 11 & 14 & 4 & & & 39 & & $1 \mathrm{x}$ & 3 & 24 & 2 & 2 & $\mathrm{x}$ & $x$ & 2 & & $\mathrm{x}$ & 2 & $\mathrm{x}$ & & & & $4 \quad 16$ & 6106 & & $\frac{0}{2}$ \\
\hline $3-4(62-64)$ & C G & & & 14 & 18 & 8 & 1 & & 41 & 18 & 2 & 1 & & 15 & 5 & 1 & 4 & 4 & & 1 & & & & & 14 & 3 & 119 & 9106 & & \\
\hline $3-5(62-64)$ & C M & & & 31 & 15 & & & & 5 & 15 & $\mathrm{x}$ & $x \times$ & & & 6 & $\mathrm{x}$ & 4 & 4 & $\mathrm{x}$ & & & $x$ & & & $\mathrm{x}$ & & 6 & 7177 & & \\
\hline $3-6(6-8)$ & F P & & & 63 & 10 & & & & 1011 & & & 1 & & & & & & & & & 1 & & & & & & 2 & 188 & & \\
\hline $3(\mathrm{CC})$ & C M & & 2 & 6 & 20 & 0 & & $\mathrm{x}$ & 142 & 11 & $3 x$ & $\mathrm{x}$ & $\mathrm{x} x$ & $x$ & $\mathrm{x}$ & & & & & & $\mathrm{x}$ & & & & & & $\mathrm{x}$ & $x \quad 153$ & & \\
\hline $4-2(65-67)$ & C P & $\mathrm{x}$ & $\mathrm{x}$ & 27 & 42 & 2 & & & 33 & 10 & 2 & 1 & 13 & 13 & 1 & & & & & & $\mathrm{x}$ & & & & & & 8 & 9186 & & \\
\hline 4-3(52-54) & R P & & & & $\mathrm{x}$ & $x$ & & & $\mathrm{x}$ & & & & $\mathrm{x}$ & & & & & & & & & & & & & & $x$ & \begin{tabular}{l|l}
$x$ & 7 \\
\end{tabular} & & \\
\hline $4-4(52-54)$ & F P & & & 39 & & & & & & 4 & & 2 & 2 & & $\mathrm{x}$ & & & & 2 & & & & & & & & $20 \quad 15$ & 5148 & & \\
\hline $4-5(65-67)$ & F P & 1 & & 61 & $\begin{array}{ll}1 & 1\end{array}$ & 4 & 1 & & & 24 & & & 2 & & 3 & & & & 1 & & & & & & & & $\begin{array}{lll}6 & 1 & 18\end{array}$ & 890 & & \\
\hline $4-6(62-64)$ & F P & 1 & & 8 & 14 & & & & & 15 & 1 & 1 & 3 & & 1 & & & & & & 1 & & & & & & $23 \quad 11$ & 1185 & & \\
\hline $4(\mathrm{CC})$ & A G & $\mathrm{x}$ & & $x \times$ & $\mathrm{xx}$ & & & & 64 & 1 & $\mathrm{x}$ & 2 & $7 x$ & & 3 & & & & 3 & & $\mathrm{x}$ & & & 1 & $\mathrm{x}$ & & 2 & 160 & & \\
\hline $5-1(68-70$ & C G & & 3 & 49 & X 2 & $2 x$ & $\mathrm{x}$ & & 42 & 2 & 2 & 3 & $21 \mathrm{X}$ & & 2 & & & & $\mathrm{x}$ & $\mathrm{x}$ & $\mathrm{x}$ & & & 4 & 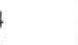 & & 1 & 1190 & & \\
\hline $5-2(62-64)$ & C M & & 6 & 27 & 23 & 32 & 22 & $\mathrm{X}$ & 34 & 3 & 14 & 6 & 121 & & $x$ & 1 & & & & & 2 & $x$ & & 5 & ; & & 2 & 1172 & & \\
\hline $5-3(60-62)$ & C G & & 10 & 20 & 2 & & 1 & $\mathrm{x}$ & 18 & $x$ & 61 & 12 & $16 \mathrm{X}$ & & $\mathrm{x}$ & & & & 2 & & 2 & $\mathrm{x} x$ & & x 3 & & & 2 & 167 & & \\
\hline $5-4(60-62)$ & C G & $\mathrm{x}$ & 5 & 257 & 4 & & 3 & 4 & 37 & $x$ & 4 & 5 & $\begin{array}{lll}X & 14 & 3\end{array}$ & & $x$ & & & & $\mathrm{x} x$ & & 1 & 1 & & 2 & 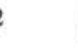 & $\mathrm{x}$ & $5 \times \mathrm{X}$ & $\mathrm{X} 190$ & & ฐँ \\
\hline $5-5(65-67)$ & F M & & 1 & 3 & & 1 & & 1 & 17 & & 3 & & 471 & & & & & & & & 1 & & & & & & 3 & 75 & & 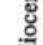 \\
\hline $5-6(63-65)$ & F G & & 6 & 14 & & 42 & 2 & & 48 & 6 & 2 & & 16 & & 22 & 2 & & & & & & & & & & & $2 \quad 10$ & 10 49 & 요 & 类 \\
\hline 5-6(135-137) & C M & & 11 & 24 & $\mathrm{x} \mathrm{x}$ & & $\begin{array}{ll}X & 1 \\
\end{array}$ & $1 \%$ & $\times 2$ & 8 & 8 & 25 & $\mathrm{x}$ & & 14 & & 2 & $\mathrm{x}$ & 1 & & 3 & & & 6 & 5 & & 21 & 1119 & $\frac{2}{2}$ & \\
\hline $5(\mathrm{CC})$ & $\mathrm{R} \mathrm{M}$ & & & 5 & & & & & 5 & 11 & & & & & 53 & & 5 & & 5 & & & & & & & & 11 & 1120 & z & \\
\hline
\end{tabular}

${ }^{2}$ Species abundance is recorded as percent of total benthonic specimens counted per sample where $\mathrm{X}=$ less than $1 \%$; percentages were not calculated for samples containing

less than 20 specimens and $\mathrm{X}$ simply denotes species presence in these samples. 
of foraminifera (Table 3), with only rare, poorly preserved specimens appearing at scattered horizons in Cores 7, 13, $19,20,21,22$, and 23 . A relatively undisturbed fine-grained interval in Core $14(203-212.5 \mathrm{~m})$ contains moderately well preserved planktonic assemblages, and Core 25 ( 381.5 to 389 meters) contains rare to common, poorly to well-preserved assemblages. Core 26 $(250-459.5 \mathrm{~m})$ is barren of all foraminifera. Abundance and preservation of benthonic foraminifera is generally similar to that noted for planktonic foraminifera (Table 16); however, rare benthonic specimens do appear at some horizons barren of planktonic species, and fragments of broken arenaceous species occur occasionally in samples otherwise devoid of all microfossils.

\section{Planktonic Foraminifera, Age, and Paleo-oceanography}

Pleistocene planktonic foraminiferal faunas characteristically dominated by sinistral-coiling populations of Globigerina pachyderma, significant percentages of $G$. bulloides (and variants), and minor percentages of $G$. quinqueloba, Globigerinita glutinata, and G. uvula occur within the 0 to 54 meter interval (Core 1 in Hole 177 and Cores 1 to 5 in Hole 177A) at Site 177. This biofacies is typical of both the Recent (Bradshaw, 1959) and Plio-Pleistocene water mass associated with the southeastern portion of the Subarctic (Alaskan) Current gyre. In fact, Vancouver Island is situated directly opposite the area where eastward-flowing North Pacific surface waters collide with the North American continent and separate into the northward-flowing Alaskan gyre and southward into the California Current (Figure 2).

The lengthy interval dominated by sinistral-coiled populations of Globigerina pachyderma within the upper portion of sediments at Site 177 (Figure 7) is correlated with the implied interval of subarctic surface termperature sensed within the California Current system during the midand later ("glacial") Pleistocene as noted at Sites 173, 174, and 175. Thus, synchronism of paleotemperature events within these two current systems is assumed. Although these subarctic faunas are correlated with Blow's (1969) Pleistocene zone N. 22 on the basis of biostratigraphic events recorded at Site 173, it is possible that zone N. 23 faunas are present but not distinguishable within the uppermost portions of Hole 177 (Figure 7).

The initial appearance of exclusively dextral-coiling populations of Globigerina pachyderma indicative of surface temperatures higher than $15^{\circ} \mathrm{C}$ occurs at the base of Core 6 (177A-6-5, 60-62 cm;60.7 m). This fauna is thought to correlate with the warm interval associated with the Pliocene-Pleistocene boundary (zones N. 22/21) within the California Current system (Site 173; Ingle 1972), although the meager assemblages within Cores 6 and 7 preclude precise definition of this boundary (Table 16; Figure 7). However, zonation of radiolarians and diatoms within this same interval confirms that this epoch boundary occurs somewhere between the base of Core 5 and the base of Core 6.

Well-developed planktonic assemblages dominated by abundances of Globorotalia puncticulata and dextral-coiling populations of Globigerina pachyderma occur in Core 14 (203 to $212.6 \mathrm{~m}$ ). The appearance of this distinct biofacies at Site 177 is indicative of a major northward migration of the transitional water mass biofacies during a period within the Pliocene when the $20^{\circ} \mathrm{C}$ isotherm was adjusted $15^{\circ}$ to $20^{\circ}$ latitude north of its present position off Baja California (Ingle, 1967, 1968, 1972). The initial phases of this major paleo-oceanographic event are correlated with Blow's (1969) zone N. 20. Pliocene appearances of the transitional water mass biofacies ${ }^{12}$ are clearly expressed at Site 173 (Figure 3), in the Mohole cores (Parker, 1964; Bandy and Ingle, 1970) and within surface sections of California (Ingle, 1967, 1968, 1972) and Washington (Fowler, 1965). Additional species making minor appearances within this biofacies at Site 177 include Globorotalia crassaformis crassaformis and G. crassaformis ronda.

Lower Pliocene faunas also containing significant percentages of Globorotalia puncticulata, dextral populations of Globigerina pachyderma, and major abundances of Globigerina bulloides, G. bulloides quadrilatera, and $G$. bulloides umbilicata occur within Core 25 (381.5 to $389 \mathrm{~m}$ ). This fauna is assigned to zone N. 19 on the basis of correlation with Pliocene biofacies variations at Site 173 (Figure 3), stratigraphic position, and correlation of Pliocene planktonic events recorded in the Wildcat Series in northern California (Ingle, 1968; Orr and Zaitzeff, 1971).

\section{Benthonic Foraminifera and Paleobathymetry}

The lithologic evidence of the turbidite origin of much of the sedimentary column present at Site 177 is consistent with the generally sparse occurrence of benthonic foraminifera within this sequence. Typical lower middle bathyal benthonic foraminiferal assemblages characterized by Melonis barleeanus, Uvigerina senticosa, and Pullenia bulloides occur at all horizons where foraminifera are present, including several intervals barren of planktonic foraminifera (Table 4). The displaced character of these sediments is emphasized by the persistent presence of species displaced from littoral, shelf, upper bathyal, and upper middle bathyal environments. Littoral and shelfdepth faunas are represented by species of Elphidium, Nonionella labradorica, and several species of Cassidulina typical of the shelf-edge environment (Table 17).

It is important to note that the stratigraphic distribution of the benthonic species Melonis pompilioides ${ }^{13}$ at Site 177 has special significance in terms of implied changes of paleodepth at Site 177. This species is rare or absent within the Pliocene portion of this sequence, implying that deposition of these beds occurred at depths shallower than 1900 meters, whereas its common presence within the Pleistocene interval $(0-54 \mathrm{~m})$ at this site implies these sediments were deposited deeper than 2200 meters. Although the tectonic sequences necessary to accommodate these proposed variations in paleodepth are perhaps complex (deposition at $1900 \mathrm{~m}+$, compression and subsidence to below $2500 \mathrm{~m}$, then uplift to present depth

\footnotetext{
${ }^{12}$ Referred to as the subtropical biofacies in some publications (Ingle, 1967).

${ }^{13}$ Melonis pompilioides occurs rarely in living faunas at 1900 to 2200 meters but occurs commonly in faunas below 2200 or 2500 meters.
} 
TABLE 16

Abundance and Stratigraphic Distribution of Planktonic Foraminifera, Site $177^{\mathrm{a}}$

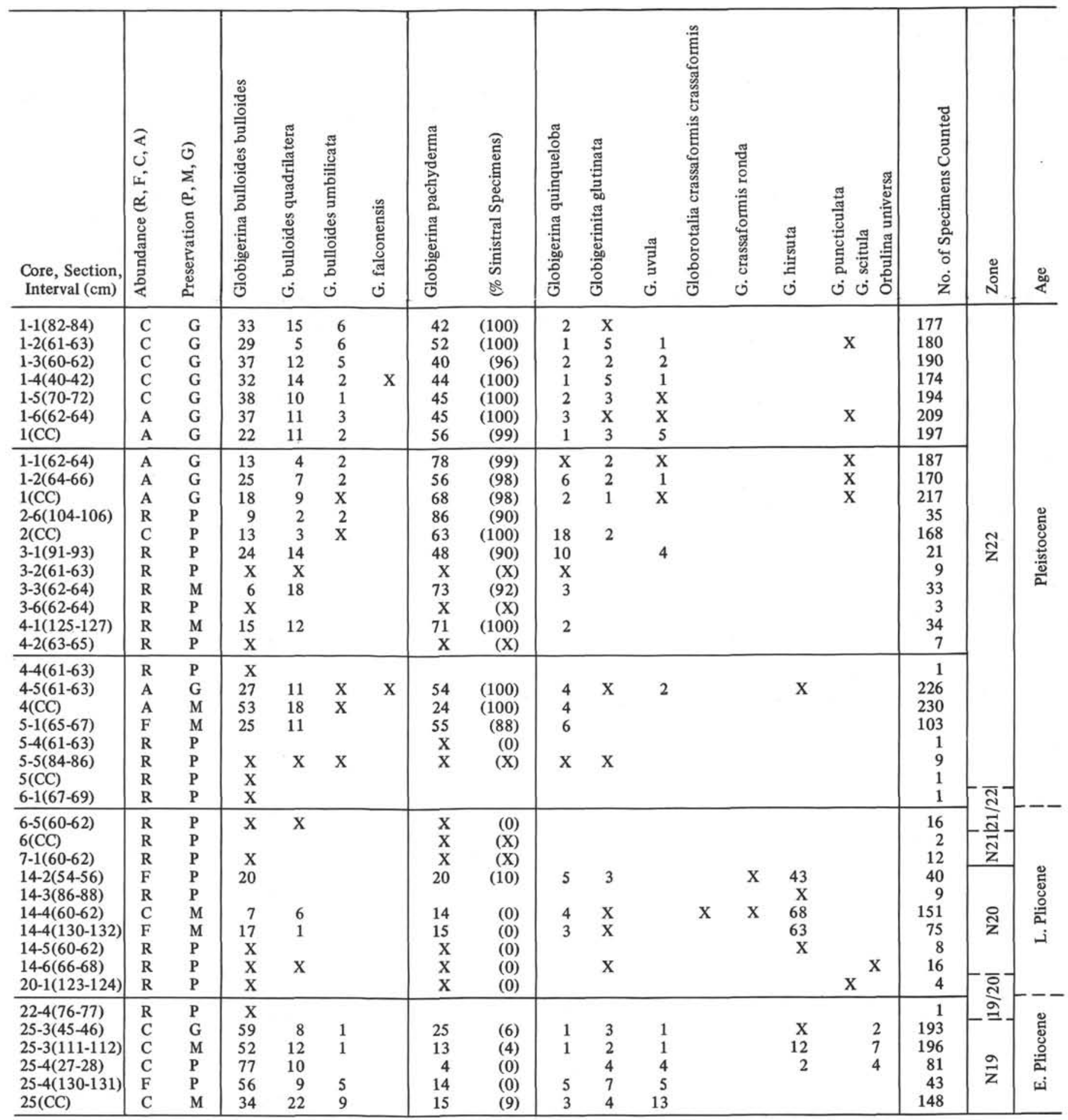

${ }^{a}$ Species abundance is recorded as percent of total planktonic specimens counted where $\mathrm{X}=$ less than $1 \%$; percentages were not calculated for samples containing less than 20 specimens and $\mathrm{X}$ simply denotes species presence in these samples.

of $2000 \mathrm{~m}$ ), they are certainly within the scope of tectonic events possible in the structurally complex setting of this location. Moreover, abundant lithologic evidence in the form of graded beds, etc., along with the common occurrence of displaced shallow-water benthonic species throughout most of the sequence penetrated at Site 177 is most certainly not indicative of a topographically isolated ridge, despite the fact that this particular PliocenePleistocene sediment package currently forms a portion of a major submarine ridge. Faunal and lithologic evidence clearly indicates that these sediments represent deposition on the distal portion of the continental rise or a submarine fan and were uplifted and deformed into their present configuration sometime in the later Pleistocene. 


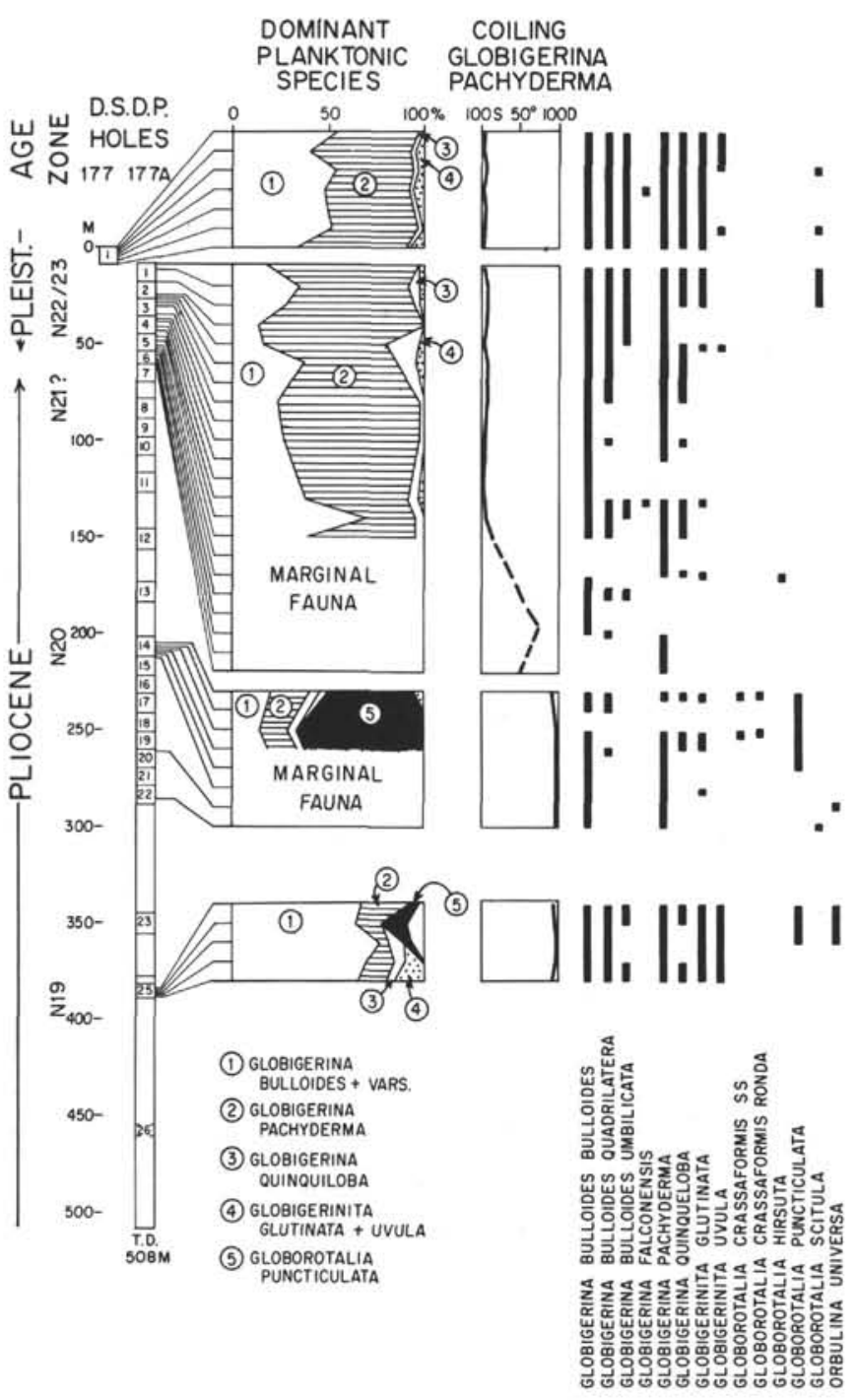

Figure 7. Stratigraphic variation of dominant planktonic species, and ranges of selected planktonic species, Site 177.

\section{SITE 178}

\section{Geologic and Stratigraphic Setting}

Site 178 is located on the Alaskan Abyssal Plain midway between Surveyor Channel and the Aleutian Trench (Figure 1). This site represents one of four sites $(178,179,180$, and 181) drilled in the Gulf of Alaska in order to scrutinize the tectonic history of this region and more specifically to aid in a understanding of the tectonic and sedimentary processes active within the Aleutian Trench-continental margin boundary. Site 178 was also selected as a potentially productive site for obtaining a biostratigraphic reference section for this high-latitude region.

Hole 178 was continuously cored to a depth of 258.5 meters and cored at selective intervals between this latter depth and the total depth of 794.5 meters. Three different lithologic units were encountered at Site 178 representing different phases in the sedimentary history of this portion of the Alaskan Abyssal Plain. The youngest unit consists of 270 meters of gray muds containing glacial erratics with the
TABLE 17

Benthonic Foraminifera Identified at Site 177

\author{
Bolivina pseudopunctata Höglund \\ Bolivina pseudoplicata Heron-Allen and Earland \\ Bulimina rostrata $\mathrm{H}$. B. Brady \\ Bulimina striata d'Orbigny var. mexicana Cushman \\ Buliminella exilis (H. B. Brady) var. tenuata Cushman \\ Cassidulina delicata Cushman \\ Cassidulina islandica Norvang \\ Cassidulina laevigata d'Orbigny \\ Cassidulina minuta Cushman \\ Cassidulina norcrossi Cushman \\ Cassidulina subglobosa Brady \\ Cassidulinoides cornuta (Cushman) \\ Chilostomella ovoidea Reuss \\ Cibicides wuellerstorfi (Schwager) \\ Eggerella bradyi (Cushman) \\ Eilohedra leviciela (Resig) \\ Elphidiella groenlandica (Cushman) \\ Elphidium sp. (broken) \\ Epistominella exigua (Brady) \\ Fursenkoina complanta (Egger) \\ Globobulimina affinis (d'Orbigny) \\ Globobulimina spinifera (Cushman) \\ Hoeglundina elegans (d'Orbigny) \\ Martinottiella communis (d'Orbigny) \\ Melonis barleeanus (Williamson) \\ Melonis pompilioides (Fichtel and Moll) \\ Nonionella labradorica (Dawson) \\ Oridorsalis umbonatus (Reuss) \\ Pullenia bulloides (d'Orbigny) \\ Pullenia quinqueloba (Reuss) \\ Pyrgo sp. \\ Pyrgo murrhina (Schwager) \\ Robulus sp. \\ Sphaeroidina bulloides d'Orbigny \\ Stilostomella sp. \\ Uvigerina auberiana d'Orbigny \\ Uvigerina hispida Cushman \\ Uvigerina peregrina Cushman \\ Uvigerina senticosa Cushman \\ Valvulineria araucana (d'Orbigny)
}

fine turbidites and encompasses the Pleistocene and later Pliocene. The interval from 270 to 742 meters is composed of diatomaceous-rich sediments, muds, and fine turbidite interbeds and represents deposition during the early Pliocene and portions of the Miocene. A truly remarkable multicolored chalk and claystone of early Miocene age was penetrated at 742 meters and is underlain by unfossiliferous clay shale. Basalt was encountered at 777.5 meters.

\section{Abundance and Preservation of Foraminifera}

Water depth at Site 178 is 4218 meters, well below the present calcium carbonate compensation level (CCL) in this region. Sampling indeed illustrates that calcareous benthonic and planktonic foraminifera are absent or rare in all post-early Miocene sediments encountered at Site 178 (Tables 3 and 18) due to apparent continuous deposition below the CCL during this interval. Rare and occasionally common specimens of poorly preserved foraminifera are present in Cores 1 to 14 ( 0 to $123 \mathrm{~m}$ ) and in Cores 18 to 29 $(150$ to $270 \mathrm{~m})$ within the Plio-Pleistocene sequence containing glacial erratics. These few productive horizons likely represent assemblages protected from aggressive bottom water by rapid burial during deposition of turbidites. Diatomaceous sediments recovered from 270 to 742 meters (Cores 30 to 52 ) are barren of foraminifera, 
with the exception of rare benthonic specimens in Cores 31,32 , and 34 , reflecting the relatively slower rate of deposition within this interval allowing complete dissolution of calcareous tests.

A relatively rich calcareous microfauna is present in the lower Miocene multicolored chalk of Core 54 (742 to 749 $\mathrm{m})$ in contrast to the great thickness of near-barren Pleistocene through mid-Miocene sediments. The appearance of calcareous sediments at this depth and latitude presents an intriguing case for speculation. The presence of high latitude-low diversity calcareous nannoplankton in this unit, along with low-diversity planktonic foraminiferal faunas, effectively rules out deposition of the chalk beneath a high productivity belt at low latitude or a downward excursion of the CCL due to increased bottom water temperature. Thus, a period of prolific productivity of calcareous nannoplankton during the early Miocene may well account for the presence of the chalk at this latitude. ${ }^{14}$

The interval of clay shales immediately above the basalt basement at Site 178 is barren of all microfossils.

\section{Planktonic Foraminifera, Age, and Paleo-oceanography}

The paucity of foraminifera throughout most of the sedimentary column at Site 178 precluded meaningful quantitative analysis of the faunas present, thus stratigraphic distribution and abundance are recorded qualitatively (Table 18).

Exclusively sinistral-coiling populations of Globigerina pachyderma, along with variable abundances of $G$. bulloides bulloides, $G$. bulloides quadrilatera, and $G$. bulloides umbilicata, and rare occurrences of G. quinqueloba, Globigerinita glutinata, G. uvula, and Globorotalia scitula, characterize Pleistocene sediments at Site 178 (0 to $123 \mathrm{~m}$; Cores 1 to 14). This subarctic biofacies in interpreted as representing surface temperatures between $5^{\circ}$ and $8^{\circ} \mathrm{C}$, although temperature may well have dropped below these values during glacial maxima.

Dominantly dextral coiling populations of Globigerina pachyderma occur at several horizons within the 150 to 255 meter interval (Cores 18 to 29 ) and are interpreted as representing a minimum surface temperature of $15^{\circ} \mathrm{C}$ within the Alaskan Current gyre. Again, correlation with planktonic events noted at Site 173 beneath the path of the California Current system indicates that the later portions of this warm event likely encompasses the boundary between zones N. 22 and N. 21 or the Pliocene-Pleistocene boundary. This epoch boundary is arbitrarily placed at the base of Core $22(195 \mathrm{~m})$ on the basis of radiolarian zonation within this interval. Planktonic faunas within Cores 25 through 28 are correlated with Blow's (1969) zone N. 21. The oldest Pliocene faunas present at Site 178 occur in Core 29 and contain dextral populations of $G$. pachyderma. These latter faunas probably represent the earliest portion of the Plio-Pleistocene warm event defined at Site 173 and are thought to correlate with the base of zone N. 21 or the top of zone N. 20 on this basis. A unique and noteworthy planktonic fauna containing an unusual

\footnotetext{
${ }^{14}$ See Wise (Chapter 15) for a full discussion of the possible origins and diagenesis of the lower Miocene chalk at Site 178.
}

abundance of Globorotalia scitula is present in Core 28 $(178-23-3,65-67 \mathrm{~cm})$.

The thick interval of diatomaceous sediments encompassing a portion of the early Pliocene through possibly the mid-Miocene interval (Cores 30 to 53) is unfortunately barren of planktonic foraminifera. However, the diatomaceous lithology of this interval suggests correlation with the Upper Miocene-Lower Miocene sequence of diatomites present at Site 173 .

The unusual multicolored chalk recovered in Core 54 $(742$ to $749 \mathrm{~m})$ contains a planktonic foraminiferal assemblage characterized by Catapsydrax dissimilis, $C$. stainforthi, $C$. unicavus s.1., Globorotalia opima nana, $G$. obesa, G. praescitula, and Globoquadrina cf. praedehiscens, along with Globorotaloides variabilis and $G$. suteri. Smaller species present include Globigerinita glutinata var., Globigerina juvenilis, and $G$. officinalis. Simple correlation on the basis of the ranges of these species as presented by Blow (1969) and making no adjustment for possible extensions or restrictions of stratigraphic ranges at this latitude indicate the faunas present in the chalk represent lower Miocene zone N. 5 through possibly the lower portion of zone N.7. A more probable age based on known ranges of these species in the cooler Californian province (Lipps, 1967; Bandy et al., 1969) suggest that these faunas are likely correlative with the lower portion of zone N. 6 . Recent analyses indicate that zone N.6 is in turn correlative with a portion of the Saucesian Stage of California according to Bandy et al. (1969), Bandy (1972), Lipps and Kalisky (1972), and as indicated at Site 173 (Figure 3).

\section{Benthonic Foraminifera and Paleobathymetry}

Sparse benthonic foraminifera found within Pleistocene and Pliocene clastic sediments at Site 178 ( 0 to $270 \mathrm{~m}$; Cores 1 to 29 ) include species common to the high-latitude lower bathyal-abyssal biofacies including Cibicides wuellerstorfi, Gyroidina cf. soldani, Melonis pompilioides, Eggerella bradyi, Cyclammina sp., and Uvigerina auberiana. Species displaced from shallower depths and transported onto the abyssal plain include Eilohedra levicula, Epistominella exigua, and Globobulimina affinis. Displaced members of shelf and littoral depth biofacies are also present within turbidite intervals, including several species of Cassidulina, Elphiduim clavatum, and E. incertum (Table 19). These latter species were transported a remarkable distance from the Alaskan strand line, probably during lower stands of sea level.

The benthonic fauna contained within the lower Miocene chalk of Core 54 is dominated by well-preserved specimens of the lower bathyal abyssal biofacies, including Cibicides kullenbergi, Oridorsalis imbonifera, Pleurostomella elliptica, Pullenia bulloides, Nuttalides umbonifera, and several species of Stilostomella (Table 19), not unlike the lower Oligocene abyssal fauna encountered at Site 172. No detectable change in paleodepth is indicated by this fauna which might assist in explaining the presence of the chalk at its present depth and latitude.

\section{SITE 179}

\section{Geologic and Stratigraphic Setting}

Site 179 is located in a narrow basin on the eastern flank of Giacomini Seamount which rises above the Alaskan 
TABLE 18

Abundance and Stratigraphic Distribution of Planktonic Foraminifera, Site 178

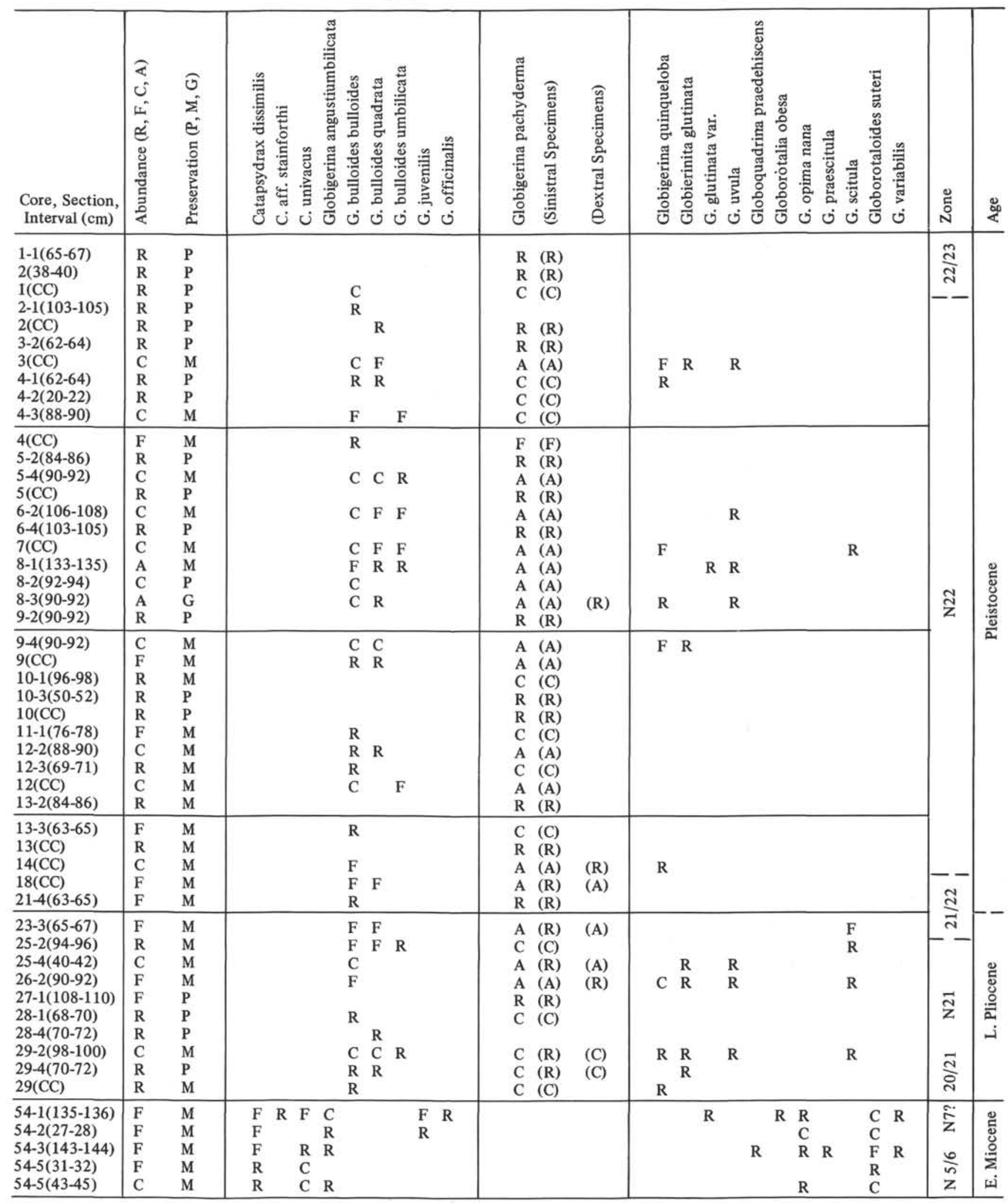


TABLE 19

Benthonic Foraminifera Identified at Site 178

Cassidulina islandica Norvang

Cassidulina subglobosa quadrata Cushman and Hughes

Cassidulina subglobosa subglobosa Brady

Cassidulina tortuosa Cushman and Hughes

Cibicides kullenbergri Parkèr

Cibicides robertsoniana (Brady)

Cibicides spiralis Natland

Cibicides wullerstorfi (Schwager)

Cyclammina sp.

Eggerella bradyi (Cushman)

Eilohedra levicula (Resig)

Elphidium clavatum Cushman

Elphidium incertum (Williamson)

Epistominella exigua (Brady)

Fissurina lucida (Williamson)

Globobulimina affinis (d'Orbigny)

Gyroidina lamarckiana (d'Orbigny)

Gyroidina aff. soldani d'Orbigny

Gyroidina subtener (Galloway and Wissler)

Gyroidina turgida (Phleger and Parker)

Melonis pompilioides (Fichtel and Moll)

Nonionella labradorica (Dawson)

Oridoisalis umbonatus (Reuss)

Pleurostomella alternans Schwager

Pleurostomella elliptica Galloway and Heminway

Pullenia quinqueloba (Reuss)

Pyrgo murrhina (Schwager)

Sphaeroidina bulloides d'Orbigny

Stainforthia nodosa (R. E. and K. C. Stewart)

Stilostomella spinea (Cushman)

Stilostomella sp.

Textularia sp.

Uvigerina auberiana d'Orbigny

Abyssal Plain southeast of Site 178 (Figure 1). Continuous coring at Site 178 penetrated 109 meters of Pleistocene green muds with infrequent turbidite layers; a weathered olivine basalt was encountered at 108 meters.

This site was originally selected in hopes of providing a biostratigraphic reference section for the Gulf of Alaska in an area essentially free of turbidite deposition. Unfortunately, only Cores 1 through $6(0$ to $51 \mathrm{~m})$ contain calcareous microfossils with siliceous microfossils present to 89 meters. Diatom zonation indicates that the PliocenePleistocene boundary occurs at or just below the base of Core $10(89 \mathrm{~m})$.

\section{Abundance and Preservation of Foraminifera}

Abundant and well-preserved planktonic foraminifera are present in Cores 1 and 2 ( 0 to $13 \mathrm{~m}$ ). Unfortunately, the abundance and preservation of planktonic specimens deteriorates rapidly below Core 2 (Table 20). However, moderately well preserved faunas again appear at the base of Core 4 and in Core 5 ( 31 to $41.5 \mathrm{~m}$ ) with sediments below this horizon essentially barren of these microfossils (Table 20).

Benthonic foraminifera are present in Cores 1 through 5 $(0$ to $41.5 \mathrm{~m})$ and are generally better preserved than planktonic specimens, although they occur less abundantly.

\section{Planktonic Foraminifera, Age and Paleo-oceanography}

Planktonic foraminiferal faunas recovered in Cores 1 through $6(0$ to $51 \mathrm{~m})$ are interpreted as Pleistocene in age, equivalent to zone N. 22, with the youngest faunas present possibly encompassing zone N. 23. As at other sites in this area a subarctic planktonic biofacies dominated by sinistral-soiling populations of Globigerina pachyderma characterizes this interval (Table 20). No evidence of major adjustment in surface temperatures was found within the interval sampled. However, future studies may illustrate that variations in the abundance of other species in this biofacies including Globigerina bulloides, G. quinqueloba, Globigerinita glutinata, G. uvula, Globorotalia hirsuta, and $G$. scitula may have environmental significance. Significantly, populations of the Globigerina bulloides complex include a number of individuals with five chambers in the final whorl assigned to G. bulloides umbilicata (Orr), a subspecies first reported from Pliocene sediments exposed in northern California (Orr and Zaitzeff, 1971) and known from the Sea of Japan (H. Ujiie, personal communication). This species may represent a Plio-Pleistocene ecophenotypic member of the $G$. bulloides s.1. complex peculiar to the colder North Pacific water masses.

All planktonic specimens recovered within Core 1 through Core 5 exhibit varying effects of dissolution due to deposition below the lysocline in the area (Berger, 1970). The oscillating appearance of these faunas below Core 2 and their complete absence below Core 6 suggests that deposition during the earlier portion of this column occurred below the calcium carbonate compensation zone, in turn implying that vertical oscillations of this critical level have occurred in this area during the last one million years. ${ }^{15}$

\section{Benthonic Foraminifera and Paleobathymetry}

In situ lower bathyal benthonic species including Melonic pompilioides and Gyroidina soldani are present in Cores 1 through 5 ( 0 to $41.5 \mathrm{~m})$ at Site 178 (Table 21). Minor percentages of species displaced from shallower bathyal depths including Cassidulina delicata, C. subglobosa quadrata, and Uvigerina hispidocostata are also present. Species displaced from littoral and shelf depths occur occasionally and include Elphidium clavatum and $E$. incertum, emphasizing the turbidite origin of some sediments at this site. Rare to common pellets of glauconite and broken mollusk shells provide additional evidence of downslope transport, possibly from adjacent Giacomini Seamount.

\section{SITE 180}

\section{Geologic and Stratigraphic Setting}

Site 180 is located in 4923 meters of water within the eastern portion of the Aleutian Trench (Figure 1). The principal objective at this site was to study the lithology of a modern trench and to search for evidence pertinent to the glacial history of the adjacent Alaskan mainland. Drilling penetrated 470.5 meters of graded Holocene-late Pleistocene silt turbidites and interbedded muds along with silt laminae and glacial erratics.

\footnotetext{
${ }^{15}$ See Wise (Chapter 15) for a more detailed discussion of possible vertical oscillations of calciumcarbonate compensation zone in this area.
} 
TABLE 20

Abundance and Stratigraphic Distribution of Planktonic Foraminifera, Site $179^{\mathrm{a}}$

\begin{tabular}{|c|c|c|c|c|c|c|c|c|c|c|c|c|c|c|c|}
\hline $\begin{array}{l}\text { Core, Section, } \\
\text { Interval }(\mathrm{cm})\end{array}$ & 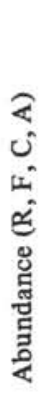 & 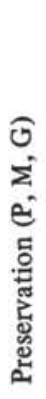 & 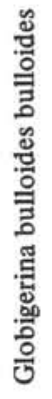 & 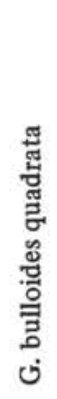 & 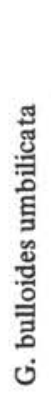 & 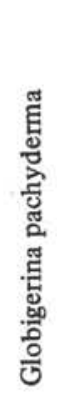 & 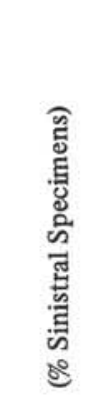 & 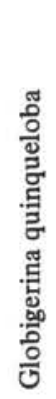 & 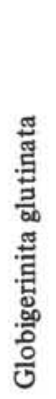 & $\begin{array}{l}\text { J } \\
\text { J゙ }\end{array}$ & 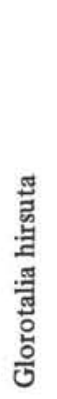 & 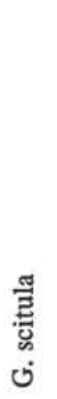 & 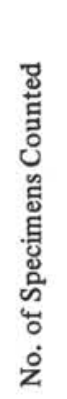 & Еू & $\stackrel{80}{<}$ \\
\hline $\begin{array}{l}1-1(138-140) \\
1-2(72-74) \\
1-3(108-110) \\
1(C C) \\
2-1(93-95) \\
2-2(93-95) \\
2-3(39-40) \\
2-4(55-57) \\
2-5(33-35) \\
2-5(90-92) \\
\end{array}$ & $\begin{array}{l}\text { C } \\
\text { R } \\
\text { A } \\
\text { A } \\
\text { A } \\
\text { C } \\
\text { C } \\
\text { C } \\
\text { C } \\
\text { A }\end{array}$ & $\begin{array}{l}M \\
P \\
G \\
G \\
G \\
P \\
G \\
M \\
M \\
\text { G } \\
\end{array}$ & $\begin{array}{r}5 \\
X \\
15 \\
13 \\
13 \\
7 \\
26 \\
33 \\
18 \\
26 \\
20 \\
\end{array}$ & $\begin{array}{r}3 \\
11 \\
5 \\
13 \\
9 \\
11 \\
3 \\
15 \\
4\end{array}$ & $\begin{array}{l}1 \\
9 \\
9 \\
5 \\
1 \\
4 \\
2 \\
1\end{array}$ & $\begin{array}{r}90 \\
\mathbf{X} \\
64 \\
78 \\
73 \\
64 \\
50 \\
76 \\
57 \\
77 \\
\end{array}$ & $\begin{array}{r}(100) \\
(\mathrm{X}) \\
(99) \\
(99) \\
(100) \\
(99) \\
(99) \\
(100) \\
(100) \\
(98) \\
\end{array}$ & $\begin{array}{l}\mathrm{X} \\
1 \\
\mathrm{X} \\
2 \\
\\
1 \\
\mathrm{X} \\
\mathrm{1} \\
\end{array}$ & & & \multicolumn{2}{|l|}{ X } & $\begin{array}{r}106 \\
12 \\
163 \\
122 \\
152 \\
160 \\
116 \\
145 \\
140 \\
196 \\
\end{array}$ & \multirow[t]{3}{*}{$\frac{\underset{N}{J}}{\mathrm{Z}}$} & \multirow{3}{*}{ 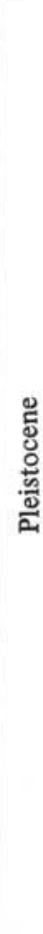 } \\
\hline $\begin{array}{l}2(C C) \\
3-1(115-117) \\
3-2(86-88) \\
3-4(104-106) \\
3-6(115-117) \\
3(C C) \\
4-1(131-132) \\
4-2(77-79) \\
4-3(60-62) \\
4-4(86-88)\end{array}$ & $\begin{array}{l}\mathrm{C} \\
\mathrm{F} \\
\mathrm{F} \\
\mathrm{R} \\
\mathrm{R} \\
\mathrm{F} \\
\mathrm{C} \\
\mathrm{R} \\
\mathrm{R} \\
\mathrm{F}\end{array}$ & $\begin{array}{l}\mathrm{M} \\
\mathrm{P} \\
\mathrm{P} \\
\mathrm{M} \\
\mathrm{P} \\
\mathrm{P} \\
\mathrm{M} \\
\mathrm{P} \\
\mathrm{P} \\
\mathrm{M}\end{array}$ & $\begin{array}{r}11 \\
14 \\
X \\
6\end{array}$ & $\begin{array}{l}1 \\
3 \\
\mathbf{X} \\
2\end{array}$ & 5 & $\begin{array}{r}65 \\
84 \\
74 \\
X \\
X \\
85 \\
77 \\
X \\
X \\
75\end{array}$ & $\begin{array}{r}(99) \\
(99) \\
(100) \\
(X) \\
(X) \\
(99) \\
(100) \\
(X) \\
(X) \\
(100)\end{array}$ & 1 & $\stackrel{3}{\mathrm{X}}$ & 17 & & $X$ & $\begin{array}{r}146 \\
119 \\
31 \\
14 \\
5 \\
79 \\
109 \\
10 \\
2 \\
52\end{array}$ & & \\
\hline $\begin{array}{l}4(C C) \\
5-1(55-57) \\
5-2(56-58) \\
5-3(40-42) \\
5-4(40-42) \\
5-5(50-52) \\
5(C C) \\
6-2(69-71) \\
6(C C)\end{array}$ & $\begin{array}{l}\mathrm{C} \\
\mathrm{A} \\
\mathrm{C} \\
\mathrm{A} \\
\mathrm{C} \\
\mathrm{C} \\
\mathrm{C} \\
\mathrm{R} \\
\mathrm{R}\end{array}$ & $\begin{array}{l}\mathrm{M} \\
\mathrm{M} \\
\mathrm{M} \\
\mathrm{G} \\
\mathrm{M} \\
\mathrm{M} \\
\mathrm{P} \\
\mathrm{P} \\
\mathrm{P}\end{array}$ & \begin{tabular}{r|r}
23 \\
12 \\
5 \\
14 \\
16 \\
11 \\
27 \\
\\
$X$
\end{tabular} & $\begin{array}{l}7 \\
5 \\
2 \\
7 \\
8 \\
8\end{array}$ & $\stackrel{3}{x}$ & $\begin{array}{r}57 \\
75 \\
65 \\
75 \\
75 \\
89 \\
62 \\
X \\
X\end{array}$ & $\begin{array}{l}(100) \\
(100) \\
(100) \\
(100) \\
(100) \\
(100) \\
(99) \\
(X) \\
(X)\end{array}$ & $\begin{array}{r}5 \\
7 \\
21 \\
X \\
X \\
1 \\
3\end{array}$ & & $\begin{array}{r}5 \\
\mathbf{X} \\
7\end{array}$ & & $\begin{array}{l}\mathrm{X} \\
\mathrm{X} \\
\mathrm{X}\end{array}$ & $\begin{array}{r}138 \\
160 \\
130 \\
202 \\
186 \\
199 \\
159 \\
2 \\
2\end{array}$ & & \\
\hline
\end{tabular}

${ }^{a}$ Species abundance is recorded as percent of total planktonic specimens counted where $\mathrm{X}=$ less than $1 \%$; percentages were not calculated for samples containing less than 20 specimens and $\mathrm{X}$ simply denotes species presence in these samples.

TABLE 21

Benthonic Foraminifera Identified at Site 179

Cassidulina delicata Cushman

Cassidulina subglobosa quadrata Cushman and Hughes

Cibicides mckannai Galloway and Wissler

Cibicides wullerstorfi (Schwager)

Cyclammina sp.

Ehrenbergina spinea

Elphidium clavatum Cushman

Elphidium incertum (Williamson)

Epistominella exigua (Brady)

Melonis barleeamus (Williamson)

Melonis pompilioides (Fichtell and Moll)

Oridorsalis umbonatus (Reuss)

Pullenia bulloides (d'Orbigny)

Pullenia quinqueloba (Reuss)

Pyrgo sp.

Textularia sp.

Trochammina sp.

Uvigerina hispidocostata Cushman

Uvigerina senticosa Cushman
Seismic records suggest that about 500 meters of trench-fill overlay the section of turbidites and hemipelagic sediment drilled at Site 178 on the adjacent Alaskan Abyssal Plain.

\section{Abundance and Preservation of Foraminifera}

Good to poorly preserved benthonic and planktonic foraminifera occur in low abundances at scattered horizons throughout the sequence penetrated at Site 180 despite the present depth of the sediment/water interface (4923 m) due to rapid burial during episodes of turbidite deposition (Tables 4 and 22). However, many planktonic specimens exhibit effects of dissolution and benthonic specimens commonly show the effects of abrasion due to distance and mode of transport.

\section{Planktonic Foraminifera, Age, and Paleo-oceanography}

Diatom and radiolarian biostratigraphy at Site 180 indicates that the entire sequence penetrated represents 
deposition during only the last 0.26 m.y. Thus, much of this section may represent Holocene deposition and dictates a staggering rate of sedimentation $(1700 \mathrm{~m} / \mathrm{m}$.y.) within the trench. The scattered planktonic foraminifera found within this section are dominated by sinistral-coiling populations of Globigerina pachyderma along with the usual accessory species, including $G$. bulloides, G. quinqueloba, Globigerinita glutinata, G. uvula, and rare occurrences of Globorotalia scitula, indicative of minimum surface temperatures hovering near $5^{\circ} \mathrm{C}$ (Table 22). No foraminiferal evidence of increased surface temperature was noted within this interval and the faunas are correlated with Holocene-Pleistocene zones N. 23 and N. 22.

\section{Benthonic Foraminifera and Paleobathymetry}

Remarkably well preserved benthonic foraminifera are present in low abundances throughout the HolocenePleistocene sequence of turbidites penetrated at Site 180. Benthonic faunas in any given sample are predominantly composed of species displaced from littoral through middle bathyal environments. Not surprisingly, species representing the in situ abyssal biofacies are rare. Littoral and shelf-depth species recognized within this sequence include Buliminella elegantissima, Nonionella miocenica stella, Cassidulina minuta, Elphidium clavatum, E. incertum, and Buccella frigida. Displaced upper bathyal and shelf-edge species present include Buliminella exilis, Cassidulina translucens, C. norcrossi, C. subglobosa, Trifarina angulosa, and Uvigerina peregrina. Upper middle bathyal species recognized include Epistominella pacifica, Cassidulina delicata, and Loxostomum pseudoberichyi with rare occurrences of lower middle bathyal through abyssal species such as Melonis pompilioides and $M$. barleeanus (Table 23).

Quantitative analysis of benthonic faunas at this site may well show meaningful variations in percentages of the various depth-dependent biofacies which in turn might assist in delineation of periods of maximum and minimum transport into this portion of the Aleutian Trench.

\section{SITE 181}

\section{Geologic and Stratigraphic Setting}

Site 181 is located on the lower continental slope about 2000 meters above the Aleutian Trench in 3080 meters of water (Figure 1). Seismic and bathymetric records in this area illustrate that deformed and steeply sloping sediments occur in this zone. The primary objectives at Site 181 focused on determination of age, provenance, and physical properties of these structurally complex deposits with the ultimate objective of relating the deformed units to thrusting of oceanic crust beneath the continent within the Aleutian Trench.

Drilling at this site penetrated a 369 meter sequence of Pleistocene deposits divisible into three distinct units on the basis of lithology and degree of consolidation and deformation. The uppermost unit ( 0 to $117 \mathrm{~m})$ consists of mud with sand and pebble erratics with decreasing sand and increasing diatoms in the second unit at 117 to 169 meters. The lower or third unit (169 to $369 \mathrm{~m}$ ) is a highly compacted, hard mudstone exhibiting microfaulting, folding, and steep dip.
Calcareous microfossils are rare below Core 2 in this sequence and suggest the bulk of this section was deposited below the calcium carbonate compensation level and later uplifted to its present depth above this level (Wise, this volume). This scenario is reinforced by the appearance of common planktonic foraminifera beginning in Core 2 and continuing through Core 1. Diatom biostratigraphy allows correlation of the base of Core $18(165.5 \mathrm{~m})$ with a radiometric age of 0.26 m.y., thus uplift implied by the appearance of carbonate material in Core 2 must have occurred within the later Holocene emphasizing the dynamic nature of tectonic processes in the Aleutian Trench area. Alternately, a downward excursion of the calcium carbonate compensation level in the last several thousand years can be invoked as the process responsible for the appearance of carbonate material at the top of the sequence penetrated at Site 181 as suggested at Site 179.

\section{Abundance and Preservation of Foraminifera}

Moderately well preserved planktonic foraminifera are few to common in Cores 1 and $2(0$ to $18.5 \mathrm{~m})$ with only sparse and, in most cases, poorly preserved individuals present below this interval (Table 24). One abundant and well-preserved fauna occurs in Core 2 (181-2-4, 26-28 cm). Benthonic foraminifera were found in scattered horizons throughout the entire sequence penetrated ( 0 to $369 \mathrm{~m}$ ). Some difficulty was experienced in extracting foraminifera from the consolidated muds in lithologic unit three (169 to $369 \mathrm{~m})$.

\section{Planktonic Foraminifera, Age, and Paleo-oceanography}

Exclusively sinistral-coiling populations of Globigerina pachyderma dominate the better preserved faunas within Cores 1 and 2 ( 0 to $18.5 \mathrm{~m}$ ) while the rare occurrences below this interval commonly consist of 1 or 2 poorly preserved specimens of this species (Table 24). Globigerina bulloides (and varieties), G. quinqueloba, Globigerinita glutinata, G. uvula, and Globorotalia scitula comprise the remaining members of this subarctic biofacies. These subarctic faunas are again correlated with the HolocenePleistocene zones N. 23 and N. 22. No evidence was found of increasing surface temperature. Diatom and radiolarian biostratigraphy at this site corroborate this age assignment and suggest the entire sequence is encompassed within the Holocene-late Pleistocene interval.

\section{Benthonic Foraminifera and Paleobathymetry}

Benthonic species displaced from shallower depths are common within the 0 to 177 meter interval (Cores 1 to 19). Littoral and shelf-depth species recognized include Buccella frigida, B. inusitata, Elphidium clavatum, E. incertum, $E$. orbiculare, Nonionella labradorica, and N. miocenica stella (Table 25). Displaced middle bathyal-upper bathyal and shelf-edge species present include Cassidulina islandica, $C$. norcrossi, C. translucens, C. subglobosa, Uvigerina peregrina, Epistominella pacifica, and Cassidulina delicata. Lower middle bathyal and lower bathyal biofacies are represented by Cibicides wuellerstorfi, Eggerella bradyi, Melonis pompilioides, Nuttalides umbonifera, and Pullenia bulloides. 
TABLE 22

Abundance and Stratigraphic Distribution of Planktonic Foraminifera, Site $180^{\mathrm{a}}$

\begin{tabular}{|c|c|c|c|c|c|c|c|c|c|c|c|c|c|c|}
\hline $\begin{array}{l}\text { Core, Section, } \\
\text { Interval }(\mathrm{cm})\end{array}$ & 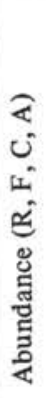 & 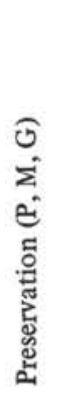 & 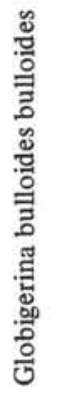 & 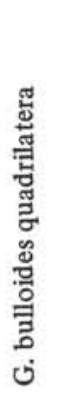 & 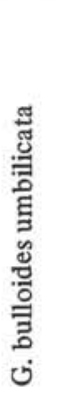 & 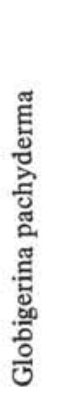 & 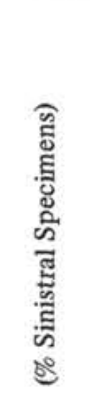 & 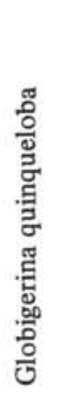 & 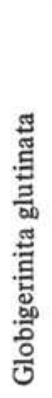 & 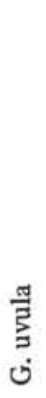 & 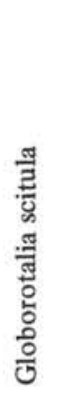 & 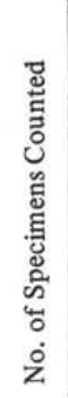 & స్ & $\stackrel{\leftrightarrow}{<}$ \\
\hline $\begin{array}{l}1-2(40-42) \\
1(C C) \\
2-2(45-47) \\
2-3(60-62) \\
3-1(137-139) \\
3(C C) \\
4-1(100-102) \\
5-1(126-128) \\
5-3(110-112) \\
5(C C)\end{array}$ & $\begin{array}{l}\mathrm{F} \\
\mathrm{R} \\
\mathrm{F} \\
\mathrm{R} \\
\mathrm{R} \\
\mathrm{R} \\
\mathrm{R} \\
\mathrm{R} \\
\mathrm{R} \\
\mathrm{R}\end{array}$ & $\begin{array}{l}\mathrm{P} \\
\mathrm{M} \\
\mathrm{M} \\
\mathrm{M} \\
\mathrm{M} \\
\mathrm{P} \\
\mathrm{P} \\
\mathrm{P} \\
\mathrm{M} \\
\mathrm{M}\end{array}$ & $\begin{array}{r}31 \\
X \\
16 \\
X \\
X \\
X \\
X \\
X \\
X \\
X\end{array}$ & $\begin{array}{l}3 \\
\mathrm{X} \\
\mathrm{X}\end{array}$ & $\begin{array}{l}3 \\
X \\
4\end{array}$ & $\begin{array}{r}52 \\
\mathrm{X} \\
74 \\
\mathrm{X} \\
\mathrm{X} \\
\mathrm{X} \\
\mathrm{X} \\
\mathrm{X} \\
\mathrm{X}\end{array}$ & $\begin{array}{r}(100) \\
(\mathrm{X}) \\
(99) \\
(\mathrm{X}) \\
(\mathrm{X}) \\
(\mathrm{X}) \\
(\mathrm{X}) \\
(\mathrm{X}) \\
(\mathrm{X})\end{array}$ & $\begin{array}{l}X \\
6 \\
X \\
X\end{array}$ & 10 & $\mathrm{X}$ & & $\begin{array}{r}29 \\
7 \\
110 \\
11 \\
8 \\
21 \\
1 \\
2 \\
7 \\
12\end{array}$ & \multirow{5}{*}{ 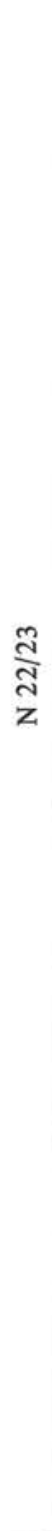 } & \multirow{5}{*}{ 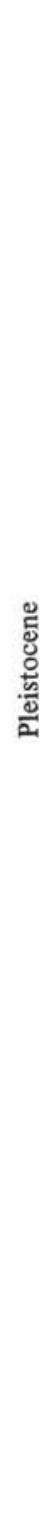 } \\
\hline $\begin{array}{l}6(C C) \\
7-1(80-82) \\
7(C C) \\
8-2(60-62) \\
8-4(60-62) \\
8(C C) \\
9(C C) \\
10(C C) \\
11(C C) \\
12-1(62-64)\end{array}$ & $\begin{array}{l}\mathrm{R} \\
\mathrm{R} \\
\mathrm{R} \\
\mathrm{F} \\
\mathrm{R} \\
\mathrm{F} \\
\mathrm{R} \\
\mathrm{R} \\
\mathrm{F} \\
\mathrm{R}\end{array}$ & $\begin{array}{l}\mathrm{M} \\
\mathrm{M} \\
\mathrm{M} \\
\mathrm{M} \\
\mathrm{M} \\
\mathrm{M} \\
\mathrm{M} \\
\mathrm{M} \\
\mathrm{M} \\
\mathrm{P}\end{array}$ & $\begin{array}{r}\mathrm{X} \\
\mathrm{X} \\
\mathrm{X} \\
11 \\
\\
16 \\
\mathrm{X} \\
\\
2\end{array}$ & 6 & & $\begin{array}{r}\mathrm{X} \\
\mathrm{X} \\
\mathrm{X} \\
83 \\
\mathrm{X} \\
81 \\
\mathrm{X} \\
\mathrm{X} \\
46 \\
\mathrm{X}\end{array}$ & $\begin{array}{r}(\mathrm{X}) \\
(\mathrm{X}) \\
(\mathrm{X}) \\
(98) \\
(\mathrm{X}) \\
(97) \\
(\mathrm{X}) \\
(\mathrm{X}) \\
(100) \\
(\mathrm{X})\end{array}$ & $\begin{array}{r}\mathrm{X} \\
50\end{array}$ & & 3 & & $\begin{array}{r}3 \\
7 \\
12 \\
53 \\
15 \\
43 \\
6 \\
3 \\
24 \\
1\end{array}$ & & \\
\hline $\begin{array}{l}13(C C) \\
14(C C) \\
15-1(130-132) \\
16-1(67-69) \\
17-3(43-45) \\
17-4(52-54) \\
18-2(60-62) \\
20-3(60-62) \\
20-4(55-57) \\
20-5(36-38)\end{array}$ & $\begin{array}{l}\mathrm{F} \\
\mathrm{R} \\
\mathrm{R} \\
\mathrm{R} \\
\mathrm{R} \\
\mathrm{R} \\
\mathrm{R} \\
\mathrm{R} \\
\mathrm{R} \\
\mathrm{R}\end{array}$ & $\begin{array}{l}\mathrm{M} \\
\mathrm{M} \\
\mathrm{M} \\
\mathrm{P} \\
\mathrm{P} \\
\mathrm{M} \\
\mathrm{M} \\
\mathrm{M} \\
\mathrm{M} \\
\mathrm{M}\end{array}$ & $\begin{array}{l}X \\
X\end{array}$ & $\begin{array}{l}\mathrm{X} \\
\mathrm{X}\end{array}$ & & $\begin{array}{l}90 \\
\mathrm{X} \\
\mathrm{X} \\
\mathrm{X} \\
\mathrm{X} \\
\mathrm{X} \\
\mathrm{X} \\
\mathrm{X}\end{array}$ & $\begin{array}{r}(100) \\
(\mathrm{X}) \\
(\mathrm{X}) \\
(\mathrm{X}) \\
(\mathrm{X}) \\
(\mathrm{X}) \\
(\mathrm{X}) \\
(\mathrm{X})\end{array}$ & $\begin{array}{l}2 \\
\mathrm{X} \\
\mathrm{X} \\
\mathrm{X} \\
\mathrm{X} \\
\\
\mathrm{X}\end{array}$ & $X$ & $\begin{array}{l}\mathrm{X} \\
\mathrm{X}\end{array}$ & & $\begin{array}{r}61 \\
1 \\
2 \\
5 \\
5 \\
7 \\
5 \\
1 \\
19 \\
19 \\
2 \\
3\end{array}$ & & \\
\hline $\begin{array}{l}22-1(70-72) \\
22-2(52-54) \\
22-3(53-55) \\
22-4(52-54) \\
22-5(40-42) \\
22-6(45-47) \\
22(C C) \\
23-2(53-55) \\
23-3(60-62) \\
23-4(56-58)\end{array}$ & $\begin{array}{l}\mathrm{R} \\
\mathrm{R} \\
\mathrm{R} \\
\mathrm{R} \\
\mathrm{F} \\
\mathrm{R} \\
\mathrm{R} \\
\mathrm{R} \\
\mathrm{R} \\
\mathrm{R}\end{array}$ & $\begin{array}{l}\mathrm{M} \\
\mathrm{M} \\
\mathrm{P} \\
\mathrm{P} \\
\mathrm{M} \\
\mathrm{P} \\
\mathrm{M} \\
\mathrm{P} \\
\mathrm{P} \\
\mathrm{P}\end{array}$ & $\begin{array}{l}\mathrm{X} \\
\mathrm{X} \\
\mathrm{X}\end{array}$ & & & $\begin{array}{r}\mathrm{X} \\
\mathrm{X} \\
\mathrm{X} \\
\mathrm{X} \\
95 \\
\mathrm{X} \\
\mathrm{X} \\
\mathrm{X} \\
\mathrm{X} \\
\mathrm{X}\end{array}$ & $\begin{array}{r}(\mathrm{X}) \\
(\mathrm{X}) \\
(\mathrm{X}) \\
(\mathrm{X}) \\
(100) \\
(\mathrm{X}) \\
(\mathrm{X}) \\
(\mathrm{X}) \\
(\mathrm{X}) \\
(\mathrm{X})\end{array}$ & & 5 & & $\begin{array}{l}X \\
X\end{array}$ & $\begin{array}{r}4 \\
8 \\
19 \\
7 \\
21 \\
8 \\
2 \\
5 \\
3 \\
11\end{array}$ & & \\
\hline $\begin{array}{l}23(C C) \\
24-1(65-67) \\
24-2(64-66) \\
24-4(40-42) \\
24(C C) \\
25-1(108-110) \\
25(C C)\end{array}$ & $\begin{array}{l}\mathrm{R} \\
\mathrm{R} \\
\mathrm{R} \\
\mathrm{R} \\
\mathrm{R} \\
\mathrm{R}\end{array}$ & $\begin{array}{l}\mathrm{M} \\
\mathrm{P} \\
\mathrm{P} \\
\mathrm{P} \\
\mathrm{M} \\
\mathrm{P}\end{array}$ & $\mathrm{X}$ & $X$ & $\mathrm{X}$ & $\begin{array}{l}\mathrm{X} \\
\mathrm{X} \\
\mathrm{X} \\
\mathrm{X} \\
\mathrm{X} \\
\mathrm{X} \\
\mathrm{X}\end{array}$ & $\begin{array}{l}\text { (X) } \\
\text { (X) } \\
\text { (X) } \\
\text { (X) } \\
\text { (X) } \\
\text { (X) } \\
\text { (X) }\end{array}$ & $\mathrm{X}$ & $\mathrm{X}$ & $\mathrm{X}$ & & $\begin{array}{r}10 \\
2 \\
5 \\
2 \\
5 \\
4 \\
1\end{array}$ & & \\
\hline
\end{tabular}

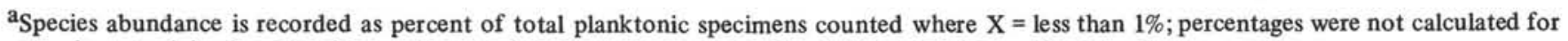
samples containing less than 20 specimens and $\mathrm{X}$ simply denotes species presence in these samples. 
TABLE 23

Benthonic Foraminifera Identified at Site 180

Bolivina pseudoplicata Heron-Allen and Earland

Bolivina sp. (broken)

Buccella frigida (Cushman)

Buliminella elegantissima (d'Orbigny)

Buliminella exilis d'Orbigny var tenuata Cushman

Cassidulina delicata Cushman

Cassidulina laevigata d'Orbigny

Cassidulimina minuta Cushman

Cassidulina norcrossi Cushman

Cassidulina subglobosa subglobosa Brady

Eilohedra levicula (Resig)

Elphidium clavatum Cushman

Elphidium incertum (Williamson)

Epistominella exigua (Brady)

Epistominella pacifica (Cushman)

Epistominella subperuviana (Cushman)

Melonis barleeanus (Williamson)

Melonis pompilioides (Fichtell and Moll)

Nonionella labradorica (Dawson)

Nonionella miocenica stella Cushman and Moyer

Quinqueloculina sp. (broken)

Trifarina angulosa (Williamson)

Uvigerina peregrina Cushman

The interval from 177 to 369.5 meters (Cores 19 to 30 ) of compacted and deformed mudstones contains only rare benthonic assemblages composed primarily of in situ bathyal species with only minor percentages of species displaced from shelf and littoral environments. This difference in composition of benthonic faunas from the overlying lithologic units implies either a different style of sedimentation, a difference in source areas, or both during deposition of the deformed mudstones.

\section{SITE 182}

\section{Geologic and Stratigraphic Setting}

Site 182 was drilled on the upper continental slope southeast of Kodiak Island at depths of 1419 and 1434 meters (Holes 182 and 182A) in an attempt to obtain a biostratigraphic reference section deposited above the calcium carbonate compensation level (Figure 1). Interval coring in Holes 182 and 182A penetrated 195 meters of Pleistocene sediment, but only 11.5 meters of core were recovered. Seismic records indicate this area is underlain by lightly folded sediments of probable Miocene through Pleistocene age. Two lithologies were encountered in these holes; a sandy mud unit with ash, erratic pebbles, and granules and an underlying unit of well-sorted fine sand with no erratics.

\section{Abundance and Preservation of Foraminifera}

Moderately well preserved planktonic and benthonic foraminifera are present in all cores recovered from Holes 182 and $182 \mathrm{~A}$ (Tables 4 and 26) with abundance varying from few to common. There is evidence that some species represent reworked specimens eroded from exposures of Late Tertiary sediments underlying the shelf.

\section{Planktonic Foraminifera, Age, and Paleo-oceanography}

The subarctic planktonic biofacies dominated by sinistrally coiling populations of Globigerina pachyderma, along with $G$. bulloides bulloides, $G$. bulloides quadrilatera,
G. bulloides umbilicata, G. quinqueloba, Globigerinita glutinata, and G. uvula, again predominates in the Pleistocene sediments penetrated at Site 182. Dextralcoiling specimens of Globigerina pachyderma appear in Core 1 of Hole 182 and suggest incursions of warmer isotherms have appeared at this latitude during portions of the Pleistocene. The appearance of these relatively warmer elements also suggests this section is somewhat telescoped and encompasses portions of the mid-or lower Pleistocene. The entire sequence is correlated with zone N. 22 and N. 23.

Several specimens of large discolored, filled, and broken dextral-coiling specimens of Globigerina pachyderma s.l. were recovered at the base of Core 6 in Hole 182. This morphology together with dextral-coiling habit suggest these specimens represent material reworked from older Pliocene sediments known to underlie portions of the shelf adjacent to Site 182. These specimens also give evidence that the Pliocene warm interval sensed in surface sections along the West Coast of North America and at other sites on this expedition was also felt at this high latitude.

\section{Benthonic Foraminifera and Paleobathymetry}

Benthonic foraminifera recovered at Site 182 are dominated by species displaced from upper bathyal and shelfedge environments (Table 27). Littoral and shelf depth elements present include Buccella sp., Elphidiella arctica, E. groenlandica, Elphidium clavatum, E. frigidum, E. incertum, Nonionella labradorica, Quinqueloculina s.p., Cassidulina islandica, C. Umbata, C. norcrossi, $C$. subglobosa, C. translucens, and Cibicides lobatulus. Upper and middle bathyal species present include Uvigerina pereqrina, $U$. hispidocostata, Epistominella pacifica, Bolivina argentea, B. interjuncta, Valvulineria araucana, and Globobulimina marginospinata. Rare broken and filled specimens of Bulimina striata mexicana and Uvigerina likely represent material reworked from Pliocene deposits exposed on the shelf and slope.

\section{FAUNAL REFERENCE LIST}

Listed below are references to the original description of each species of planktonic foraminifera mentioned in this report along with various taxonomic notes on selected species. All trinominals represent genus, species, and subspecies. Preferred modern names are followed by the original designation and reference.

Planktonic Foraminifera

Cassigerinella chipolensis (Cushman and Ponton) $=$ Cassidulina chipolensis Cushman and Ponton, 1932, Florida Geol. Survey, Bull. 9, p. 98, pl. 15, figs. 2a-c.

Catapsydrax dissimilis (Cushman and Bermudez) $=$ Globigerina dissimilis Cushman and Bermudez, 1937, Contr. Cushman Lab. Foram. Res., vol. 13, pt. 1, p. 25, pl. 3, figs. 4-6.

Catapsydrax stainforthi Bolli, Loeblich and Tappan, 1957, U.S. Natl. Mus. Bull. 215, p. 37, pl. 7, fig. 11.

A single poorly preserved specimen of rather small size was recovered from Sample 178-54-1, 135-136 cm, and assigned to C. aff. stainforthi. Well-developed specimens were recovered from Site 173 (Table 7).

Catapsydrax unicavus Volli, Loeblich and Tappan, 1957, U.S. Natl. Mus. Bull. 215, p. 37, pl. 7, fig. 9.

Catapsydrax unicavus primativus (Blow and Banner) $=$ Globigerinito unicava primativa Blow and Banner, 1962, in Eames, F., Banner, F. T., Blow, W. H. and Clarke, W. J., Fundamentals of 
TABLE 24

Abundance and Stratigraphic Distribution of Planktonic Foraminifera, Site $181^{\mathrm{a}}$

\begin{tabular}{|c|c|c|c|c|c|c|c|c|c|c|c|c|c|c|}
\hline $\begin{array}{l}\text { Core, Section, } \\
\text { Interval }(\mathrm{cm})\end{array}$ & 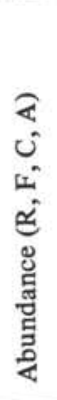 & 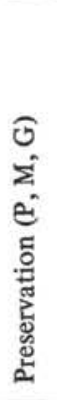 & 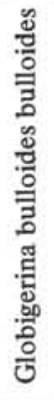 & 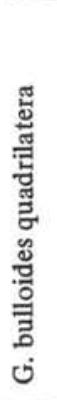 & 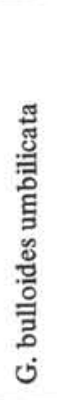 & 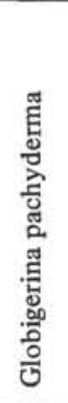 & 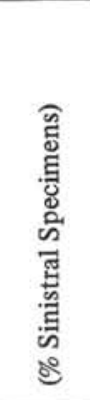 & 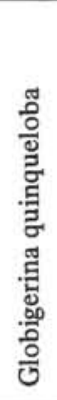 & 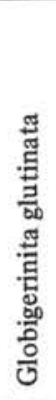 & $\begin{array}{l}\frac{\text { Jै }}{3} \\
ن\end{array}$ & 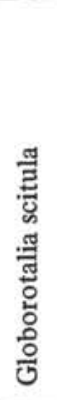 & 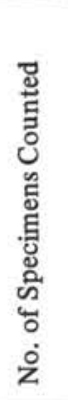 & ָั & $\stackrel{8}{<}$ \\
\hline $\begin{array}{l}1-1(87-89) \\
1-2(67-69) \\
1-3(70-72) \\
1-4(67-68) \\
1-5(126-128) \\
1-6(65-67) \\
1(C C) \\
2-1(54-56) \\
2-2(80-82) \\
2-3(17-19) \\
\end{array}$ & $\begin{array}{l}\text { C } \\
\text { C } \\
\text { C } \\
\text { C } \\
\text { F } \\
\text { C } \\
\text { C } \\
\text { F } \\
\text { F } \\
\text { C }\end{array}$ & $\begin{array}{l}\mathrm{M} \\
\mathrm{M} \\
\mathrm{M} \\
\mathrm{M} \\
\mathrm{M} \\
\mathrm{M} \\
\mathrm{P} \\
\mathrm{M} \\
\mathrm{P} \\
\mathrm{G}\end{array}$ & $\begin{array}{r}11 \\
6 \\
9 \\
6 \\
18 \\
1 \\
7 \\
7 \\
7 \\
7 \\
15\end{array}$ & $\begin{array}{l}5 \\
5 \\
3 \\
3 \\
\\
5 \\
1 \\
9 \\
3 \\
5\end{array}$ & $\begin{array}{l}1 \\
5 \\
1 \\
2 \\
1 \\
1\end{array}$ & $\begin{array}{l}78 \\
89 \\
86 \\
87 \\
79 \\
92 \\
90 \\
83 \\
90 \\
79\end{array}$ & $\begin{array}{r}(100) \\
(100) \\
(100) \\
(100) \\
(100) \\
(99) \\
(99) \\
(100) \\
(100) \\
(100)\end{array}$ & $\begin{array}{c}5 \\
\\
\mathrm{X} \\
1 \\
\mathrm{X} \\
\mathrm{X} \\
1 \\
1\end{array}$ & & & & $\begin{array}{r}129 \\
94 \\
134 \\
135 \\
112 \\
156 \\
123 \\
46 \\
29 \\
151\end{array}$ & \multirow{5}{*}{$\begin{array}{l}\stackrel{\text { d }}{\mathrm{d}} \\
\mathrm{z}\end{array}$} & \multirow{5}{*}{ 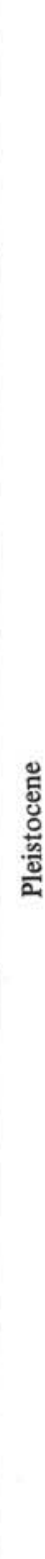 } \\
\hline $\begin{array}{l}2-4(26-28) \\
2-5(80-82) \\
2-6(77-79) \\
3-2(52-54) \\
3(C C) \\
5-1(106-108) \\
5(C C) \\
6-3(66-68) \\
7-1(26-28) \\
7-2(52-54) \\
\end{array}$ & $\begin{array}{l}\mathrm{A} \\
\mathrm{F} \\
\mathrm{F} \\
\mathrm{R} \\
\mathrm{R} \\
\mathrm{R} \\
\mathrm{R} \\
\mathrm{R} \\
\mathrm{R} \\
\mathrm{R}\end{array}$ & $\begin{array}{l}\mathrm{M} \\
\mathrm{M} \\
\mathrm{M} \\
\mathrm{M} \\
\mathrm{M} \\
\mathrm{P} \\
\mathrm{P} \\
\mathrm{P} \\
\mathrm{P} \\
\mathrm{P}\end{array}$ & $\begin{array}{l}10 \\
11 \\
11\end{array}$ & 4 & 2 & $\begin{array}{l}84 \\
89 \\
89 \\
\mathrm{X} \\
\mathrm{X} \\
\mathrm{X} \\
\mathrm{X} \\
\mathrm{X} \\
\mathrm{X} \\
\mathrm{X}\end{array}$ & $\begin{array}{r}(100) \\
(100) \\
(100) \\
(\mathrm{X}) \\
(\mathrm{X}) \\
(\mathrm{X}) \\
(\mathrm{X}) \\
(\mathrm{X}) \\
(\mathrm{X}) \\
(\mathrm{X}) \\
\end{array}$ & & & & & $\begin{array}{r}274 \\
57 \\
47 \\
1 \\
1 \\
2 \\
1 \\
1 \\
8 \\
2 \\
\end{array}$ & & \\
\hline $\begin{array}{l}7-3(89-91) \\
7(C C) \\
8-2(85-87) \\
8-5(76-78) \\
9-1(69-71) \\
9-2(66-68) \\
9-3(83-85) \\
9(C C) \\
11(C C) \\
12-1(120-122) \\
\end{array}$ & $\begin{array}{l}\mathrm{R} \\
\mathrm{R} \\
\mathrm{R} \\
\mathrm{R} \\
\mathrm{R} \\
\mathrm{R} \\
\mathrm{R} \\
\mathrm{R} \\
\mathrm{R} \\
\mathrm{R}\end{array}$ & $\begin{array}{l}\mathrm{P} \\
\mathrm{M} \\
\mathrm{P} \\
\mathrm{P} \\
\mathrm{P} \\
\mathrm{P} \\
\mathrm{P} \\
\mathrm{P} \\
\mathrm{P} \\
\mathrm{M} \\
\end{array}$ & $\begin{array}{l}X \\
X \\
\end{array}$ & & & $\begin{array}{l}\mathrm{X} \\
\mathrm{X} \\
\mathrm{X} \\
\mathrm{X} \\
\mathrm{X} \\
\mathrm{X} \\
\mathrm{X} \\
\mathrm{X} \\
\mathrm{X} \\
\mathrm{X}\end{array}$ & $\begin{array}{l}(X) \\
(X) \\
(X) \\
(X) \\
(X) \\
(X) \\
(X) \\
(X) \\
(X) \\
(X) \\
\end{array}$ & & & & & $\begin{array}{r}2 \\
2 \\
1 \\
1 \\
6 \\
19 \\
2 \\
1 \\
1 \\
5 \\
\end{array}$ & & \\
\hline $\begin{array}{l}12-2(109-111) \\
12(C C) \\
13-1(69-71) \\
13-2(62-64) \\
13-3(56-58) \\
13-5(51-53) \\
13(C C) \\
14-1(119-121) \\
14-2(90-92) \\
14(C C) \\
\end{array}$ & $\begin{array}{l}\mathrm{R} \\
\mathrm{R} \\
\mathrm{R} \\
\mathrm{R} \\
\mathrm{R} \\
\mathrm{R} \\
\mathrm{R} \\
\mathrm{R} \\
\mathrm{R} \\
\mathrm{R}\end{array}$ & $\begin{array}{l}\mathrm{M} \\
\mathrm{P} \\
\mathrm{P} \\
\mathrm{P} \\
\mathrm{M} \\
\mathrm{M} \\
\mathrm{P} \\
\mathrm{G} \\
\mathrm{P} \\
\mathrm{P}\end{array}$ & $\begin{array}{l}\mathbf{X} \\
\mathbf{X} \\
\mathbf{X} \\
\mathbf{X}\end{array}$ & $\mathrm{X}$ & & $\begin{array}{l}\mathrm{X} \\
\mathrm{X} \\
\mathrm{X} \\
\mathrm{X} \\
\mathrm{X} \\
\mathrm{X} \\
\mathrm{X} \\
\mathrm{X} \\
\mathrm{X} \\
\mathrm{X}\end{array}$ & $\begin{array}{l}\text { (X) } \\
\text { (X) } \\
\text { (X) } \\
\text { (X) } \\
\text { (X) } \\
\text { (X) } \\
\text { (X) } \\
\text { (X) } \\
\text { (X) } \\
\text { (X) }\end{array}$ & $\begin{array}{l}\mathrm{X} \\
\mathrm{X}\end{array}$ & & & & $\begin{array}{l}1 \\
2 \\
3 \\
4 \\
8 \\
3 \\
1 \\
1 \\
3 \\
8 \\
1\end{array}$ & & \\
\hline $\begin{array}{l}15-5(63-65) \\
15(C C) \\
17-3(45-47) \\
17-5(65-67) \\
17(C C) \\
18-2(110-112) \\
18-3(55-57) \\
18-4(35-37)\end{array}$ & $\begin{array}{l}\mathrm{R} \\
\mathrm{R} \\
\mathrm{R} \\
\mathrm{R} \\
\mathrm{R} \\
\mathrm{F} \\
\mathrm{R} \\
\mathrm{R}\end{array}$ & $\begin{array}{l}\mathrm{M} \\
\mathrm{M} \\
\mathrm{P} \\
\mathrm{M} \\
\mathrm{M} \\
\mathrm{M} \\
\mathrm{M} \\
\mathrm{M}\end{array}$ & $\begin{array}{l}X \\
5 \\
X\end{array}$ & $\begin{array}{l}\mathrm{X} \\
\mathrm{X}\end{array}$ & & $\begin{array}{c}\mathrm{X} \\
(\mathrm{X}) \\
\mathrm{X} \\
\mathrm{X} \\
\mathrm{X} \\
94 \\
\mathrm{X} \\
\mathrm{X}\end{array}$ & $\begin{array}{r}(\mathrm{X}) \\
(\mathrm{X}) \\
(\mathrm{X}) \\
(\mathrm{X}) \\
(\mathrm{X}) \\
(100) \\
(\mathrm{X}) \\
(\mathrm{X})\end{array}$ & $\begin{array}{l}\mathrm{X} \\
\mathrm{X} \\
\mathrm{X}\end{array}$ & $X$ & & $\mathrm{X}$ & $\begin{array}{r}1 \\
15 \\
1 \\
4 \\
8 \\
30 \\
30 \\
10 \\
2\end{array}$ & & \\
\hline
\end{tabular}

${ }^{a}$ Species abundance is recorded as percent of total planktonic specimens counted where $\mathrm{X}=$ less than $1 \%$; percentages were not calculated for samples containing less than 20 specimens and $\mathrm{X}$ simply denotes species presence in these samples. 
TABLE 25

Benthonic Foraminifera Identified at Site 181

Bolivina argentea Cushman

Buccella frigida (Cushman)

Buccella inusitata Anderson

Buliminella exilis d'Orbigny var. temuata Cushman

Cassidulina delicata Cushman

Cassidulina islandica Norvang

Cassidulina laevigata d'Orbigny

Cassidulina minuta Cushman

Cassidulina norcrossi Cushman

Cassidulina subglobosa s.s. d'Orbigny

Cassidulina translucens Cushman and Hughes

Cassidulinoides cornuta (Cushman)

Cibicides lobatulus (Walker and Jacob)

Cibicides spiralis Natland

Cibicides wullerstorfi (Schwager)

Eilohedra levicula (Resig)

Elphidium clavatum Cushman

Elphidium incertum (Williamson)

Elphidium orbiculare (Brady)

Epistommella exigua (Brady)

Epistominella pacifica (Cushman)

Epistominella subperuviana (Cushman)

Globobulimina affinis (d'Orbigny)

Gyroidina soldani d'Orbigny

Gyroidina subtener (Galloway and Wissler)

Melonis pompilioides (Fichtell and Moll)

Nonionella labradorica (Dawson)

Nonionella miocenica stella Cushman and Moyer

Pullenia bulloides (d'Orbigny)

Pullenia quinqueloba (Reuss)

Trifarina angulosa (Williamson)

Trifarina baggi (Galloway and Wissler)

Uvigerina auberiana d'Orbigny

Uvigerina hispidocostata Cushman and Todd

Uvigerina peregrina Cushman

Uvigerina senticosa Cushman
Mid-Tertiary Stratigraphical Correlation. Cambridge Univ. Press, London, p. 114, pl. XIV, Figs. J-L.

The genus Catapsydrax is retained in light of recent studies which clearly indicate (as does surface ultrastructure) that these forms have a distinct rod-like nonspinose wall structure (Lipps, 1966); emphasis is not placed on absence or presence of a bulla.

Globigerina cf. angiporoides Horibrook, 1965, New Zealand Jour. Geol. Geophys., vol. 8 , no. 5, p. 836, fig. 1a, b, and d.

Extremely rare, poorly preserved specimens with characteristically smooth round chambers, coarsely perforate wall structure, but having rather atypical apertures were recovered in an early Oligocene sample at Site $172(172-3-6,54-55 \mathrm{~cm})$ and tentatively assigned to this species.

Globigerina angulisuturalis Bolli, 1957, U.S. Natl. Mus. Bull 215, p. 109 , pl. 22, figs. 11a-c.

Globigerina angustiumbilicata Bolli $=$ Globigerina ciperoensis angustiumbilicata Bolli, 1957, U.S. Natl. Mus. Bull. 215, p. 109, pl. 22, figs. $12 \mathrm{a}-13 \mathrm{c}$.

This small species of simple morphology is considered the immediate ancestor of G. quinqueloba (Natland) and is characteristic of lower and middle Miocene deposits in the North Pacific (Asano et al., 1968). Globigerina angustiumbilicata is considered indicative of temperate and cool surface temperatures. Intergrading populations of these two species are found within the late Miocene after which $G$. quinqueloba becomes predominant.

Globigerina apertura Cushman, 1918, U.S. Geol. Survey Bull., no. 676 , p. 57 , pl. 12 , figs. $8 \mathrm{a}-8 \mathrm{c}$.

Globigerina bulloides bulloides d'Orbigny, 1826, Ann. Sci. Nat., ser. 1, vol. 7, p. 277; Modeles, no. 76.

Globigerina bulloides quadrilatera Galloway and Wissler $=$ Globigerina quadrilatera Galloway and Wissler, 1927, Jour. Paleo., vol. 1, no. 1, p. 44, 84, pl. 7, fig. 11.

This subspecies of $G$. bulloies s.s. is characterized by a diminutive fifth chamber in the final whorl. Studies of both Recent and fossil populations of this subspecies have not demonstrated meaningful patterns in variations of the frequency of this form to date, although it may well have ecologic significance.

TABLE 26

Abundance and Stratigraphic Distribution of Planktonic Foraminifera, Site 182

\begin{tabular}{|c|c|c|c|c|c|c|c|c|c|c|c|c|c|}
\hline $\begin{array}{l}\text { Core, Section, } \\
\text { Interval }(\mathrm{cm})\end{array}$ & 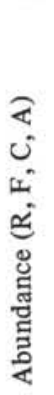 & 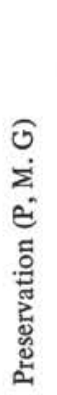 & 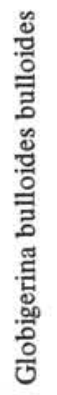 & 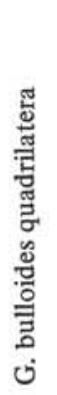 & 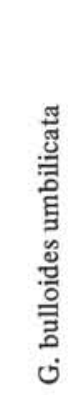 & 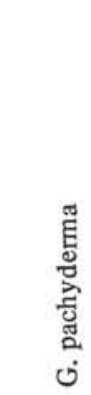 & 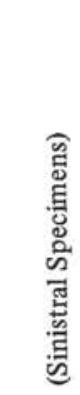 & 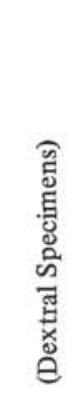 & 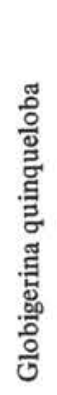 & 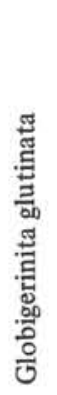 & $\begin{array}{l}\frac{\pi}{3} \\
ن\end{array}$ & हొ & $\stackrel{\circ}{<}$ \\
\hline $1-1(112-114)$ & $\mathrm{C}$ & G & F & R & & A & (A) & & $\mathrm{R}$ & & & $\stackrel{m}{N}$ & \multirow{13}{*}{ 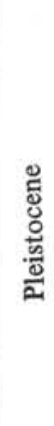 } \\
\hline $1-2(69-71)$ & A & M & F & F & & A & (A) & & $\mathrm{F}$ & & & ป & \\
\hline $1-3(54-56)$ & A & M & $\mathrm{F}$ & $\mathrm{F}$ & & A & (A) & & & & & z & \\
\hline $1-4(50-52)$ & A & M & $\mathrm{F}$ & $\mathrm{F}$ & $\mathrm{R}$ & A & (A) & & $\mathrm{R}$ & & & & \\
\hline $1-5(53-55)$ & A & G & C & $\mathrm{C}$ & $\mathrm{C}$ & A & (A) & & $\mathrm{R}$ & & $\mathrm{R}$ & & \\
\hline $1-6(47-49)$ & A & G & C & $\mathrm{C}$ & C & A & (A) & (R) & $\mathbf{R}$ & & $\mathrm{R}$ & & \\
\hline $1(\mathrm{CC})$ & A & G & C & C & $\mathrm{C}$ & A & (A) & (R) & $\mathrm{R}$ & & $\mathrm{R}$ & & \\
\hline $3-1(86-88)$ & $\mathrm{C}$ & $\mathrm{G}$ & $\mathrm{C}$ & $\mathrm{C}$ & $\mathbf{R}$ & A & (A) & (R) & $\mathrm{R}$ & & $\mathrm{R}$ & & \\
\hline $3-2(106-108)$ & A & $\mathrm{M}$ & C & & $\mathrm{R}$ & A & (A) & (R) & & & $\mathbf{R}$ & & \\
\hline $3(\mathrm{CC})$ & $\mathrm{C}$ & G & $\mathrm{C}$ & $\mathrm{R}$ & & A & (A) & & $\mathrm{R}$ & & & ป & \\
\hline $4(\mathrm{CC})$ & $\mathrm{F}$ & M & C & R & & (A) & (A) & (R) & $\mathrm{R}$ & & & z & \\
\hline $5(C C)$ & $\mathrm{R}$ & $\mathrm{M}$ & $\mathrm{R}$ & & & $\mathrm{C}$ & (C) & & $\mathrm{R}$ & & & & \\
\hline $6(\mathrm{CC})$ & $\mathrm{F}$ & $\mathrm{M}$ & $\mathrm{R}$ & & & $\mathrm{C}$ & (C) & (R) & & & & & \\
\hline
\end{tabular}


TABLE 27

Benthonic Foraminifera Identified at Site 182

Bolivina argentea Cushman

Bolivina interjuncta Galloway and Wissler

Bolivina pacifica Cushman and McCulloch

Bolivina pseudoplicata Heron-Allen and Earland

Buccella sp.

Bulimina marginata Cushman

Bulimina pagoda Cushman

Bulimina striata d'Orbigny var. mexicana Cushman

Buliminella exilis d'Orbigny var. tenuata Cushman

Cassidulina californica Cushman \& Hughes

Cassidulina crassa d'Orbigny

Cassidulina delicata Cushman

Cassidulina islandica Norvang

Cassidulina laevigata d'Orbigny

Cassidulina laevigata carinata Cushman

Cassidulina limbata Cushman \& Hughes

Cassidulina minuta Cushman

Cassidulina norcrossi Cushman

Cassidulina subglobosa quadrata Cushman and Hughes

Cassidulina subglobosa subglobosa Brady

Cassidulina translucens Cushman and Hughes

Cassidulinoides bradyi (Norman)

Cibicides fletchei Galloway and Wissler

Cibicides lobatulus (Walker and Jacob)

Chilostomella fimbricata Cushman

Elphidiella arctica (Parker and Jones)

Elphidiella groenlandica (Cushman)

Elphidium clavatum Cushman

Elphidium Frigrdum Cushman

Elphidium incertum (Williamson)

Epistominella exigua (Brady)

Epistominella pacifica (Cushman)

Glandulina laevigata d'Orbigny

Globobulimina auriculata (Bailey) var arctica Hoglund

Globobulimina marginospinata (Cushman and Parker)

Lagena hexagona (Williamson)

Lagena striata (d'Orbigny)

Lagena striato-punctata Parker and Jones

Loxostomum pseudobeyrichi (Cushman)

Melonis barleeanus (Williamson)

Nonionella labradorica (Dawson)

Oridorsalis umbonatus (Reuss)

Pullenia bulloides (d'Orbigny)

Pullenia quinqueloba (Reuss)

Pyrgo depressa (d'Orbigny)

Pyrgo murrhina (Schwager)

Quinqueloculina sp.

Quinqueloculina subrotunda (Montagu)

Sphaeroidina bullioides d'Orbigny

Trifarina angulosa (Williamson)

Uvigerina auberiana d'Orbigny

Uvigerina hispida Cushman

Uvigerina hispidocostata Cushman and Todd

Uvigerina juncea Cushman and Todd

Uvigerina peregrina Cushman

Valvulineria araucana (d'Orbigny)

Globigerina bulloides umbilicata Orr and Zaitzeff $=$ Globigerina umbilicata Orr and Zaitzeff, 1971, Jour. Foram. Res., Vol. 1, no. 1 , p. 18 , pl. 1, figs. 1-3.

This morphotype, originally described as a distinct species, is herein considered a subspecies of $G$. bulloides s.s., easily distinguished on the basis of five to six large well-developed chambers in the final whorl and a large open umbilicus. Quantitative analysis of populations in Pliocene sediments exposed in northern California at the type locality (Ingle, 1968) nor variations recorded in sites drilled during Leg 18 have yielded meaningful frequency patterns although this form is considered an ecophenotypic variant of $G$. bulloides. This subspecies has not been observed in Recent populations by the writer and is limited to late Pleistocene through middle Miocene sediments at Site 173. Thus, it may well prove to be a useful index to the Holocene-Pleistocene boundary in high latitude areas if the stratigraphic range established for this species in sites drilled on Leg 18 is corroborated in other areas. It is best developed and most abundant within late Pliocene and Pleistocene deposits at sites drilled on Leg 18.

Globigerina concinna Reuss, 1850, K. Akad. Wiss. Wien, Denkschr., Math.-Nat. K1., vol. 1, p. 373, pl. 47, fig. 8.

The original figure of this species provided by Reuss is of marginal value, however, Marks (1951) has provided excellent figures of this form from the type area and specimens from the California Miocene and those encountered at Site 173 are identical in every respect.

Globigerina decoraperta Takayanagi and Saito, 1962, Tohoku Univ., Science Repts., Sec. Ser. (Geology), Spec. Vol., no. 5, p. 85, pl. 28 , figs. 10 a-c.

This species exhibits a wide range of morphologic variation; smaller specimens are difficult to distinguish from $G$. druyi to which $G$. decoraperta may be related.

Globigerina druyi Akers, 1955, Jour. Paleo., vol. 29, no. 4, p. 645, pl. 65 , figs. 1a-c.

Globigerina euaperta Jenkins, 1960, Micropaleontology, vol. 6, no. 4, p. 351 , pl. 1 , figs. 8 a-c.

Globigerina falconensis Blow, 1959, Bull. Amer. Paleo, vol. 39, no. 178 , p. 177 , pl. 9 , figs. $40 \mathrm{a}-\mathrm{c}$.

Globigerina foliata Bolli, 1957, U.S. Natl. Mus. Bull. 215, p. 111, pl. 24 , figs. 1a-c.

Globigerina juvenilis Bolli, 1957, U.S. Natl. Mus. Bull. 215, p. 110, pl. 24 , figs. 5 a- 6 .

This species may in fact simply represent a variant or stage of Globigerinita glutinata as recognized in the original description; both aperture and wall structure are more typical of Globigerinita despite the consistant lack of a bulla. The early development of the Globigerinita glutinata - naparimaensis group is badly in need of study. The form referred to Globigerinita glutinata var. at Site 173 appears to represent a distinct older variant within this long ranging stock.

Globigerina repenthes Todd, 1957, U.S. Geol. Survey Prof. Paper $280-\mathrm{H}$, p. 301 , pl. 78 , fig. 7.

Only those specimens possessing an extremely distinct thumblike final chamber were included within this species although intergrades with $G$. decoraperta were observed at Site 173 .

Globigerina officinalis Subbotina, 1953, Trudim VNIGRI, N.S., no. 76 , p. 78 , pl. 11, figs. 1a-c.

Globigerina pachyderma $($ Ehrenberg $)=$ Aristerospira pachyderma Ehrenberg, 1961, K. Akad, Wiss. Berlin, Monatsber., p. 276-277, $303 ; 1873$, pl. 1 , fig. 4 .

A multitude of opinions exist as to the taxonomic and stratigraphic position of this species. However, one central fact stands out, this species does indeed constitute the most prominent planktonic foraminifer inhabiting polar and subarcticsubantarctic water masses today. Moreover, repeated studies (see Kennett, $1968 \mathrm{~b}$, and references therein) have demonstrated that this morphotype exhibits a preferential coiling habit with sinistral coiling forms dominant in surface sediments beneath waters cooler than $10^{\circ} \mathrm{C}$ whereas dextral forms are dominant in surface sediments beneath waters warmer than $15^{\circ} \mathrm{C}$. Moreover, the range of Globigerina pachyderma s.l. has been established as Late Miocene (approximate base of zone N.13) to Recent in California (Bandy and Ingle, 1970), New Zealand (Jenkins, 1967; Kennett, 1968a, b), Japan (Asano et al., 1969), and Italy (Cita et al., 1965). This range is again corroborated at Site 173 (Figure 3). The morphology of this species is variable (Kennett, $1968 \mathrm{~b}$ ), and forms within the limits of Globigerina incompta Cifelli have been included within $G$. pachyderma of this report.

Globigerina parva Bolli, 1957, U.S. Natl. Mus. Bull. 215, p. 108, pl. 22, figs. 142-c.

Globigerina prasaepsis Blow, 1969, Proc. First Intern. Plank. Conf., vol. I, E. J. Brill, Leiden, p. 382, pl. 10, fig. 13; pl. 18, fig. 3-7.

Globigerina praebulloies Blow, 1959, Bull. Amer. Paleo., vol. 39, no. 178 , p. 180 , pl. 8 , figs. 47 a-c; pl. 9 , fig. 48 .

Globigerina quinqueloba Natland, 1938, Scripps Inst. Oceanogr., Bull., Tech. Serv., vol. 4 , no. 5, p. 149, pl. 6, fig. 7 . 
Globigerinita glutinata $($ Egger $)=$ Globigerina glutinata Egger, 1895, K. Bayer Akad. Wiss., Math-Phys. I1., Abh., vol. 18, pt. 2, p. 371 , pl. 13, figs. 19-21.

Globigerinita glutinata var. A.

Late Miocene and older populations of Globigerinita glutinata s.l. from Site 173 include an increasing number of smaller individuals possessing a relatively large bulla with only one or two infralaminal apertures. When broken, the primary aperture on the final chamber possesses a thin lip similar to forms included within Globigerina juvenilis. Many of these morphotypes fall within the restricted morphologic range of Globigerinita naparimaensis Bronnimann as discussed by Blow $(1959$, p. 329), but further study is needed on this group to clarify the status of these related and perhaps conspecific forms.

Globigerinita uvula $($ Ehrenberg $)=$ Polydexia uvula Ehrenberg, 1861, K. Preuss, Akad. Wiss. Berlin, Monatsber., p. 276, 277, 308.

Globigerinoides bolli Blow, 1959, Bull. Amer. Paleo., vol. 39, no. 178 , p. $189-190$, pl. 10 , figs. 65 a-c.

Globigerinoides obliquis Bolli, 1957, U.S. Natl. Mus., Bull. 215, p. 113 , pl. 25 , figs. $9 \mathrm{a}-10 \mathrm{c}$.

Globigerinoides quadrilobatus (d'Orbigny), 1846, = Globigerina quadrilobata d'Orbigny, Ann. Sci. Nat., ser 1, t. 7, p. 164, pl. 9, figs 7-10. (lectotype of Banner and Blow, 1960, used under protest).

Globigerinoides ruber (d'Orbigny) = Globigerina ruber d'Orbigny, 1838, Foraminiferes, in de la Sagra, Hist. Phys. Pol. Nat. Cuba, p. 82 , pl. 4 , figs. $12-14$.

Globoquadrina acostaensis $($ Blow) = Globorotalia acostaensis Blow, 1959, Bull. Amer. Paleo., vol. 39, no. 178 , p. 208 , pl. 17, fig. 106.

Globoquadrina dehiscens (Chapman, Parr, and Collins) = Globorotalia dehiscens Chapman, Parr, and Collins, 1934, Linn. Soc. London, (Zoology), Jour., vol. 38 , no. 262 , p. 569 , pl. 11 , fig. 36.

Globoquadrina dutertrei (d'Orbigny) = Globigerina dutertrei d'Orbigny, 1839, in de la Sagra, Hist. Phys. Pol. Nat. Cuba, p. 84 , pl. 4, figs. 19-21.

Globoquadrina humerosa $($ Takayanagi and Saito $)=$ Globorotalia humerosa Takayanagi and Saito, 1962, Tohoku Univ., Sci. Repts., Sec. Ser. (Geology), Spec. Vol., no. 5, p. 78, pl. 28, figs 1-2.

Globoquadrina praedehiscens Blow and Banner, 1962, in Eames, Banner, Blow, and Clarke, Fundamentals of Mid-Tertiary Stratigraphical Correlation, Cambridge Univ. Press, Cambridge, p. 116, pl. XV, figs. Q-S.

Globoquadrina venezuelana $($ Hedberg $)=$ Globigerina venezuelana Hedberg, 1937, Jour. Paleo., vol. 11, p. 681, pl. 92, fig. 7.

Globorotalia crassaformis crassaformis (Galloway and Wissler) = Globigerina crassaformis Galloway and Wissler, 1927, Jour. Paleo., vol. 1, p. 41, pl. 7, fig. 12.

Globorotalia crassaformis oceanica Cushman and Bermudez, 1949, Contrib. Cushman Lab. Foram. Res., Vol. 25, p. 43, pl. 8, figs. 13-15.

This subspecies along with $G$. crassaformis ronda has been shown to represent an ecophenotypic variant of $G$. crassaformis s.s. (Lidz, 1972). Thus, the stratigraphic utility ascribed to these two subspecies by some workers should be reexamined. Both forms were found to be restricted to relatively warmer water planktonic biofacies in the northeastern Pacific and Gulf of Alaska.

Globorotalia crassaformis ronda Blow, 1969, Proc. First Intern. Plank. Conf., Vol. 1, E. J. Brill, Leiden, p. 388 , pl. 4, figs. 4-6; pl. 37, figs. 6-9.

Globorotalia crassula Cushman and R. E. Stewart, 1930, San Diego Soc. Nat. Hist., Trans., vol. 6, p. 77, pl. 7, fig. 1 .

Globorotalia continuosa Blow, 1959, Bull. Amer. Paleo., vol. 39, no. 178 , p. 218 , pl. 19 , fig. 125 .

Globorotalia hirsuta (d'Orbigny) = Rotalina hirsuta d'Orbigny, 1839, in Barker-Webb and Berthelot, Hist. Nat. Iles Canares, vol. 2 , pt. 2, p. 131, pl. 1, figs. 37-39.

Globorotalia inflata (d'Orbigny) = Globigerina inflata d'Orbigny, 1839 , in Barker-Webb and Berthelot, Hist. Nat. Iles Carnares, vol. 2, pt. 2, p. 134 , pl. 2, figs. 7-9.

Globorotalia margaritae Bolli and Bermudez, 1965, Boll. Asoc. Venezolana Geol. Mineria Petrol., vol. 8, no. 5, p. 121.
Globorotalia mayeri Cushman and Ellisor, 1939, Contrib. Cushman Lab. Foram. Res., vol. 15, pt. I, p. II, pl. 2, figs. 4 a-c.

Globorotalia menardi (d'Orbigny) = Rotalia menardi d'Orbigny, 1826, Ann. Sci. Nat., ser. 1, vol. 7, p. 273; Modeles no. 10.

Globorotalia minutissima Bolli, 1957, U. S. Natl. Mus. Bull. 215, p. 119 , pl. 29, figs. 1a-c.

Globorotalia miozea Finlay, 1939, Roy. Soc. New Zealand, Trans., vol. 69 , pt. 3, p. 326.

Globorotalia miozea conoidea Walters, 1965, New Zealand Jour. Geol. \& Geophys., vol. 8, p. 124, fig. 8, I-M.

Globorotalia opima nana Bolli, 1957, U. S. Natl. Mus. Bull. 215, p. 118 , pl. 28 , figs. $3 \mathrm{a}-\mathrm{c}$.

Globorotalia obesa Bolli, 1957, U. S. Natl. Mus. Bull. 215, p. 119, pl. 29, figs. 2a-3.

Globorotalia peripheroronda Blow and Banner, 1966, Micropaleontology, vol. 12, no. 3, p. 294, pl. 1, figs. 1a-c.

Globorotalia praescitula Blow, 1959, Bull. Amer. Paleo., vol. 39, no. 178 , p. 221 , pl. 19 , fig. 128 .

Globorotalia puncticulata (d'Orbigny) $=$ Globigerina puncticulata d'Orbigny, 1932, in Deshayes, Encyclopedie Methodique, vol. 2, pt. 2, p. 170.

Globorotalia scitula $($ Brady) = Pulvinulina scitula Brady, 1882, Roy. Soc. Edinburgh Proc., vol. 11, p. 716.

Globorotalia scitula var.

Rare specimens of a small turborotalid with a rounded periphery and five chambers in the final whorl were found within Miocene horizons at Site 173. This species closely resembles an un-named sp. of Globorotalia described from Miocene sediments in the Mohole by Parker (1964, p. 631).

Globorotalia tosaensis Takayanagi and Saito, 1962, Tohoku Univ., Sci. Repts., Sec. Ser. (Geology), Spec. Vol., no. 5, p. 81, pl. 28, figs 12,12 .

Only a single specimen of this species was found at Site 173 although further sampling within Cores 5 through 8 of this hole may produce more specimens.

Globorotalia tumida (Brady) = Pulvinulina menardi (d'Orbigny) var. tumida Brady, 1977, Geol. Mag., new ser., dec. 2, vol. 4, no. 12, p. 535.

Globorotaloides hexagona (Natland) $=$ Globigerina hexagona Natland, 1938, Univ. Calif., Scripps Inst. Oceanog., Bull., Tech. Ser., vol. 4 , no. 5 , p. 149 , pl. 7 , fig. 1 .

Globorotaloides suteri Bolli, 1957, U. S. Natl. Mus. Bull. 215, p. 117 , pl. 27, figs. 9a-13c.

Globorotaloides suteri relizensis Bandy, Ingle, and Wright, 1971, Jour. Foram. Res., vol. 1, no. 1, p. 15, pl. 1, figs. 1-4.

Globorotaloides trema Lipps, 1964, Tulane Studies in Geol., vol. 2, no. 4 , p. 128 , pl. IV, figs 3a-c.

Globorotaloides variabilis Bolli, 1957, U. S. Natl. Mus. Bull. 215, p. 117 , pl. 27, figs. $15 \mathrm{a}-20 \mathrm{c}$.

Orbulina suturalis Bronnimann, 1951, Contr. Cushman Found. Foram. Res., vol. 2, p. 135, text-figs. 1-2, 5-8, 10.

Orbulina universa d'Orbigny, 1839, Foraminiferes, in de la Sagra, Hist. Phys. Pol. Nat. Cuba, P. 3, pl. 1, fig. 1.

The possible polyphyletic origins of this and related morphotypes are still in dispute as are the stratigraphic ranges of members of the "Orbulina" lineage (Parker, 1962; Bandy et al., 1965,1969 C) across latitude. However, the stratigraphic range of this "species" at Site 173 confirms the notion that the Orbulina datum surface occurs within the provincial Miocene Relizian Stage of California (Kleinpell, 1938).

Praeorbulina glomerosa circularis Blow, 1956, Micropaleontology, vol. 2 , no. 1 , p. 65 , text-figs 2 , nos. 3-4.

Praeorbulina glomerosa glomerosa Blow, 1956, Micropaleontology, vol. 2 , no. 1 , p. 65 , text-figs. 1 , nos. $15-19$.

Sphaeroidinellopsis seminulina $($ Schwager $)=$ Globigerina seminulina Schwager, 1866, Novara-Exped., Geol., vol. 2, pt. 2, p. 256, pl. 7 , fig. 112 .

\section{ACKNOWLEDGMENTS}

I would like to thank the Deep Sea Drilling Project and the sponsoring agency, the National Science Foundation, for having given me the opportunity of participating in Leg 18 aboard the Glomar Challenger. Thanks are also due Prof. 
R.H. Jahns, Dean of the School of Earth Sciences, Stanford University, for his encouragement and support of my participation in this expedition. A special acknowledgment and debt of thanks is extended to Dr. Vern Kulm and Dr. Roland Von Huene, co-chief scientists on Leg 18 , for their initial invitation to join Leg 18 and for their continued help, leadership, and patience both at sea and onshore.

\section{REFERENCES}

Addicott, W. O., 1969. Tertiary climatic changes in the marginal northeastern Pacific Ocean. Science. 165, 583.

Arrhenius, G., 1963. Pelagic sediments. In Hill, M. N. (Ed.), The Sea, Vol. 3. New York (Interscience Publ.). 655.

Asano, K., Ingle, J. C., Jr., and Takayanagi, Y., 1968. Origin and development of Globigerina quinqueloba Natland in the North Pacific. Science Repts. Tohoku Univ. Japan. Sec. Ser. (Geology), 39(3), 213.

1969. Neogene planktonic foraminiferal sequence in northeastern Japan. Proc. First Intern. Planktonic Conf. I, Leiden (E. J. Brill). 14.

Atwater, T., 1970. Implications for plate tectonics for the Cenozoic tectonic evolution of Western North America. Bull. Geol. Soc. Am. 81, 3513.

Atwater, T. and Menard, H., 1970. Magnetic lineations in the northeast Pacific. Earth Planet. Sci. Letters. 7, 445.

Bandy, O. L., 1960. The geologic significance of coiling ratios in the foraminifer Globigerina pachyderma (Ehrenberg). J. Paleontol. 34(4), 671.

1963. Dominant paralic foraminifera of southern California and the Gulf of California. Contrib. Cushman Found. Foram. Res. 14(4), 127.

1966. Restrictions of the "Orbulina" datum. Micropaleontology. 10(1), 1.

, 1967. Foraminiferal definition of the boundaries of the Pleistocene in southern California. In Sears, M. (Ed.) Progress in Oceanography, Vol. 4. New York (Pergamon Press). 27.

1971. Recognition of Upper Miocene Neogene Zone 18, experimental Mohole, Guadalupe Site. Nature. 233(5320), 476.

1972. Neogene planktonic foraminiferal zones, California, and some geologic implications. In Lipps, J. H. (Ed.), Eastern Pacific Plankton Biostratigraphy and Paleoecology. Paleogeog., Paleoclim., Paleoecol. 12(1/2), 131.

Bandy, O. L. and Chierichi, M. A., 1966. Depthtemperature evaluation of selected California and Mediterranean bathyal foraminifera. Marine Geol. 4, 259.

Bandy, O. L. and Ingle, J. C., Jr., 1970. Neogene planktonic events and radiometric scale, California. In Bandy, O. L. (Ed.), Radiometric Dating and Paleontologic Zonation. Geol. Soc. Am. Spec. Paper 124. 131.

Bandy, O. L. and Kolpack, R. L., 1963. Foraminiferal and sedimentological trends in the Tertiary section of Tecolote Tunnel, California. Micropaleontology. 9(2) 117.

Bandy, O. L., Ingle, J. C., Jr., and Frerichs, W. E., 1965. Geologic significance of isomorphism in planktonic foraminifera (abstract). Geol. Soc. Am. Programs for 1965. 9.

Bandy, O. L., Butler, E. A. and Wright, R. C., 1969a. Alaskan Upper Miocene marine glacial deposits and the Turborotalia pachyderma datum plane. Science. 166, 607.
Bandy, O. L., Morin, R. W. and Wright, R., $1969 \mathrm{~b}$. Definition of the Catapsydrax stainforthi Zone in the Saucesian Stage of California. Nature. 222, 468.

Bandy, O. L., Vincent, E., and Wright, R. C., 1969c. Chronologic relationships of orbulines to the Globorotalia foshi lineage. Rev. Esp. Micropaleontologia, vol. 1, no. 2, p. 131-145.

Bandy, O. L., Casey, R. E. and Wright, R. C., 1971. Late Neogene planktonic zonation, magnetic reversals, and radiometric dates, Antarctic to the tropics. Am. Geophys. Union, Anarctic Res. Ser. (Antarctic Oceanology). 15,1 .

Banner, F. T. and Blow, W. H., 1965. Progress in planktonic foraminiferal biostratigraphy of the Neogene. Nature. 208 (5016), 1154.

Berger, W. H., 1970. Planktonic foraminifera: selective solution and the lysocline. Marine geol. 8, 111 .

Berggren, W. A., 1969. Cenozoic chronostratigraphy, planktonic foraminiferal zonation and the radiometric time-scale. Nature. 224(5224), 1072. 1971. Tertiary boundaries and correlations. In Funnell, B. and Riedel, W. R. (Eds.), Micropaleontology of the Oceans. Cambridge (Cambridge Univ. Press). 693. 1972. A Cenozoic time-scale - some implications for regional geology and paleobiology. Lethaia. 5, 195. Blow, W. H., 1969. Late Middle Eocene to Recent planktonic foraminiferal biostratigraphy. Proc. First Intern. Conf. Planktonic Microfossils. I, Leiden (E. J. Brill). 199.

Bradshaw, J. S., 1959. Ecology of living planktonic foraminifera in the North and equatorial Pacific. Contrib. Cushman Found. Foram. Res. 10(2), 25.

Burkle, L. H., 1971. Correlation of Late Cenozoic marine sections in Japan and the equatorial Pacific. Trans. Proc. Paleontol. Soc. Japan, N. S. 82, 117.

Byrne, J. V., Fowler, G. A. and Malone, N. J., 1966. Uplift of the continental margin and possible continental accretion off Oregon. Science. 154, 1654.

Casey, R. E., 1972. Neogene radiolarian biostratigraphy and paleotemperatures, the experimental Mohole, Antarctic core E 148. Paleogeog., Paleoclim., Paleoecol. 12, 115.

Cifelli, R., 1969. Radiation of Cenozoic planktonic foraminifera. Systematic Zool. 18 (2), 154.

Cita, M. B., Premoli Silva, I. and Rossi, R., 1965. Foraminiferi plantonici del Tortoniano-tipo. Riv. Ital. Paleont. 71(1), 217.

Coopera, W. C., 1961. Intertidal foraminifera of the California and Oregon coast. Contrib. Cushman Found. Foram. Res. 12(2), 47.

Curray, J. R., 1965. Late Quaternary history, continental shelves of the United States. In Wright, H. E., Jr. and Frey, D. G. (Eds.). The Quaternary of the United States. Princeton Univ. Press. 723.

Cushman, J. A., Stewart, R. E. and Stewart, K. C., 1930. Tertiary foraminifera from Humbolt County, California. Trans. San Diego Soc. Nat. History. 6(2), 41.

Devereux, I., 1967. Oxygen isotope paleotemperature measurements on New Zealand Tertiary fossils. New Zealand J. Sci. 10, 988.

Duncan, J. R., Jr., 1968. Later Pleistocene and post-glacial sedimentation and stratigraphy of deep sea environments off Oregon. PhD. dissertation. Oregon State Univ., Corvallis, Oregon. 222 p.

Duncan, J. R., Fowler, G. A. and Kulm, L. D., 1970. Planktonic foraminiferan-radiolarian ratios and Holocene-Late Pleistocene deep sea stratigraphy off Oregon. Bull. Geol. Soc. Am. 81, 561. 
Emery, K. O., 1965. Characteristics of continental shelves and slopes. Bull. Am. Assoc. Petrol. Geologists. 49, 1379.

Emiliani, C., 1954. Temperatures of Pacific bottom waters and polar superficial waters during the Tertiary. Science. $119,853$.

Ericson, D. B., 1959. Coiling direction of Globigerina pachyderma as a climatic index. Science. 130 (3369), 219.

Faustman, W. F., 1963. Paleontology of the Wildcat Group at Scotia and Centerville Beach, California. Univ. California, Publ. Geol. Sci. 41 (2), 97.

Feyling-Hanssen, R. W., 1964. Foraminifera in Late Quaternary deposits from the Oslofjord area. Norges Geologiske Undersokelse. 225. 383 p.

Fowler, F. A., 1965. The stratigraphy foraminifera and paleoecology of the Montesano Formation, Grays Harbor County, Washington. Unpub. PhD thesis. Univ. Southern California. $355 \mathrm{p}$.

Fowler, G. A. and Kulm, L. D., 1970. Foraminiferal and sedimentologic evidence for uplift of the deep-sea floor, Gorda Rise, Northeastern Pacific. J. Marine Res. 28, 321.

Heath, G. R., 1969. Carbonate sedimentation in the abyssal equatorial Pacific during the past 50 million years. Bull. Geol. Soc. Am. 80, 689.

Hedgpeth, J. W., 1957. Classification of marine environments. Geol. Soc. Am. Mem. 67, 1, 17.

Ikebe, N., Takayanagi, Y., Chiji, M. and Chinzei, K., 1972. Neogene biostratigraphy and radiometric time scale of Japan - an attempt at intercontinental correlation. Pacific Geol. 4, 39.

Ingle, J. C., Jr., 1963. Paleoecologic, sedimentary, and structural history of the Late Tertiary Capistrano Embayment, Orange County, California (abstract). Bull. Am. Assoc. Petrol. Geologists. 47 (2), 361.

1967. Foraminiferal biofacies and the MiocenePliocene boundary in southern California. Bull. Am. Paleontol. 52 (236), 217.

1968. Pliocene planktonic foraminifera from northern California and paleo-oceanographic implications (abstract). Geol. Soc. Am. Spec. Paper 121. 147.

1972. Biostratigraphy and paleoecology of Early Miocene through Early Pleistocene benthonic and planktonic foraminifera, San Joaquin Hills-Newport Bay, Orange County, California. In Stinemeyer, E. H. (Ed.), The Pacific Coast Miocene Biostratigraphic Symposium, March 9-10, 1972, Bakersfield, California. Pacific Sect., Soc. Econ. Paleontol. Mineral. 255.

Jenkins, D. G., 1966. Planktonic foraminifera from the type Aquitanian Burdigalian of France. Contrib. Cushman Found. Foram. Res. 17 (1), 1.

1967. Planktonic foraminiferal zones and new taxa from the Lower Miocene to Pleistocene of New Zealand. New Zealand J. Geol. Geophys. 10, 1964.

Kennett, J. P., 1967. Recognition and correlation of the Kapiteau Stage (Upper Miocene, New Zealand). New Zealand J. Geol. Geophys. 10, 1051.

1968a. Paleo-oceanographic aspects of the foraminiferal zonation in the Upper Miocene-Lower Pliocene of New Zealand. Giorn. Geologia (2). 35 (3), 143.

1968b. Latitudinal variation in Globigerina pachyderma (Ehrenberg) in surface sediments of the southwest Pacific Ocean. Micropaleontology. 14 (3), 305 .
Kennett, J. P., Burns, R. E., Andrews, J. E., Churkin, M., Jr., Davies, T. A., Dumitrica, P., Edwards, A. R., Galehouse, J. S., Packham, G. H. and Van der Lingen, G. J., 1972. Australian-Antarctic continental drift, palaeocirculation changes and Oligocene deep-sea erosion. Nature, Phys. Sci. 239, 51.

Kent, D., Opdyke, N. D. and Ewing, M., 1971. Climate change in the North Pacific using ice-rafted detritus as a climatic indicator. Bull. Geol. Soc. 82, 2741.

Kheradpir, A., 1970. Foraminiferal trends in the Quaternary of Tanner Basin, California. Micropaleontology. 16(1), 102.

Kleinpell, R. M., 1938. Miocene stratigraphy of California. Am. Assoc. Petrol. Geologists. Tulsa. 450 p.

Kulm, L. D. and Fowler, G. A., 1971. Shallow structural elements of the Oregon continental margin within a plate tectonic framework. Geol. Soc. Am. Abstracts, 3(7) 628.

Loeblich, A. R., Jr. and Tappan, H., 1953. Studies of Arctic Foraminifera. Smithsonian Misc. Collections. 121, (7). $150 \mathrm{p}$.

Lidz, B., 1972. Globorotalia crassaformis morphotype variations in Atlantic and Caribbean deep-sea cores. Micropaleontology. 18, 194.

Lipps, J. H., 1964. Miocene planktonic foraminifera from Newport Bay, California. Tulane Studies in Geology. 2 (4), 109.

, 1966. Wall structure, systematics, and phylogeny studies of Cenozoic planktonic foraminifera. J. Paleontol. 40, (6), 1257.

1967. Planktonic foraminifera, intercontinental correlation and age of the California mid-Cenozoic microfaunal stages. J. Paleontol. 41 (4), 994.

Lipps, J. H. and Kalisky, M., 1972. Calcareous nannoplankton biostratigraphy and paleoecology. In Steinmeyer, E.H. (Ed.), The Pacific Coast Miocene Biostratigraphic Symposium, March 9-10, 1972, Bakersfield, Calif., Pac. Sec., Soc. Econ. Paleontol. Mineral. 239.

Manske, D. C., 1968. Distribution of Recent foraminifera in relation to estaurine hydrography, Yaquina Bay, Oregon, Unpub. PhD. dissertation, Oregon State Univ., Corvallis, Oregon.

Margolis, S. V. and Kennett, J. P., 1971. Cenozoic paleoglacial history of Antarctica recorded in subAntarctic deepsea cores. Am. J. Sci. 271, 1.

McKeel, D. R. and Lipps, J. H., 1972. Calcareous plankton from the Tertiary of Oregon. Paleogog., Paleoclim. Paleoecol., 12, 75.

Morin, R. W., 1971. Late Quaternary biostratigraphy of cores from beneath the California Current. Micropaleontology. 7 (4), 435.

Murray, J. W. and Tiffin, D. L., 1969. Structure of the continental margin west of Vancouver Island, British Columbia. Geol. Surv. Canada. Paper 69-1 A. 14.

Natland, M. L., 1957. Paleoecology of West Coast Tertiary sediments. In Ladd, H. S. (Ed.), Treatise on Marine Ecology and Paleoecology. Geol. Soc. Am. Mem. 67. 2, 543.

Nelson, C. H., 1968. Marine geology of Astoria deep-sea fan. Phd. dissertation. Oregon State Univ., Corvallis, Oregon. 287 p.

Ogle, B. A., 1953. Geology of the Eel River Valley area, Humbolt County, California. Calif. Div. Mines Bull. 164. $128 \mathrm{p}$.

Olsson, R. K., 1971. Pliocene-Pleistocene planktonic foraminiferal biostratigraphy of the Northeastern Pacific. Proc. II Planktonic Conf., Rome. II. 921. 
Orr, W. and Zaitzeff, J. B., 1971. A new planktonic species from the California Pliocene. J. Foram. Res. 1, 17.

Parker, F. L., 1962. Planktonic species in Pacific sediments. Micropaleontology. 8 (2), 219.

1964. Foraminifera from the experimental MOHOLE drilling near Guadalupe Island, Mexico. J. Paleontol. 38 (4), 617.

1967. Late Tertiary biostratigraphy (planktonic foraminifera) of tropical Indo-Pacific deep-sea cores. Bull. Am. Paleontol. 52 (235). 208 p.

Rau, W. W., 1970. Foraminifera, stratigraphy, and paleoecology of the Quinault Formation, Point Grenville-Raft River coastal area, Washington. Washington Div. Mines Geol. Bull. 62. 41 p.

Roth, P. H., Baumann, P. and Bertolino, V., 1971. Late Eocene-Oligocene calcareous nannoplankton from central and northern Italy. Proc. II Intern. Planktonic Conf., Rome. 1970. Rome (Edizioni Technozcienza) 1069.

Saito, T., 1963. Miocene planktonic foraminifera from Honshu, Japan. Sci. Repts. Tohoku Univ., Sec. Series (Geol.). 35, 123.

Silver, E. A., 1969. Late Cenozoic underthrusting of the continental margin off northernmost California. Science. 166,1265 .

1971a. Transitional tectonics and Late Cenozoic structure of the continental margin off northernmost California. Bull. Geol. Soc. Am. 82, 1. 1971b. Tectonics of the Mendocino Triple Junction. Bull. Geol. Soc. Am. 82, 2965.

$1971 \mathrm{c}$. Small plate tectonics in the northeastern Pacific. Bull. Geol. Soc. Am. 82, 3491.

Theyer, F., 1973. New zonation for interval Gilbert to Gauss. Nature. 241 (112), 142.

Tiffin, D. L., Cameron, B. E. B. and Murray, J. W., 1972. Tectonics and depositional history of the continental margin off Vancouver Island, British Columbia. Canadian J. Earth Sci. 9 (3), 280.

Towe, K. M. and Cifelli, R., 1957. Wall ultrastructure in the calcareous foraminifera: crystallographic aspects and a model for calicification. J. Paleontol. 41 (3), 742.

Tully, J. P., 1965. Oceanographic regions and processes in the seasonal zone of the North Pacific Ocean. In Yoshida, K. (Ed.), Studies in Oceanography. (Hidaka Memorial Volume). Univ. Washington Press, Seattle. p. 68 .

Turner, D. L., 1970. Potassium-argon dating of Pacific Coast Miocene foraminiferal stages. In Bandy, O. L. (Ed.), Radiometric Dating and Paleontologic Zonation. Geol. Soc. Am. Spec. Paper. 124. 91.

Wolfe, J. A. and Hopkins, D. M., 1967. Climatic changes recorded by Tertiary land floras in northwestern North America. In Hatai, K. (Ed.), Tertiary Correlations and Climatic Changes in the Pacific. Japan, Univ. Tokyo, 11th Pacific Sci. Congr. 67. 